\title{
SUMMARY OF THE FUEL ROD SUPPORT SYSTEM (GRIDS) DESIGN FOR LWBR (LWBR Development Program)
}

FEBRUARY 1979

CONTRACT EY-76-C-11-0014

\section{BETTIS ATOMIC POWER LABORATORY WEST MIFFLIN, PENNSYLVANIA}

Operated for the U. S. Department of Energy by WESTINGHOUSE ELECTRIC CORPORATION 


\section{DISCLAIMER}

This report was prepared as an account of work sponsored by an agency of the United States Government. Neither the United States Government nor any agency Thereof, nor any of their employees, makes any warranty, express or implied, or assumes any legal liability or responsibility for the accuracy, completeness, or usefulness of any information, apparatus, product, or process disclosed, or represents that its use would not infringe privately owned rights. Reference herein to any specific commercial product, process, or service by trade name, trademark, manufacturer, or otherwise does not necessarily constitute or imply its endorsement, recommendation, or favoring by the United States Government or any agency thereof. The views and opinions of authors expressed herein do not necessarily state or reflect those of the United States Government or any agency thereof. 


\section{DISCLAIMER}

Portions of this document may be illegible in electronic image products. Images are produced from the best available original document. 
SUMMARY OF THE FUEL ROD SUPPORT SYSTEM (GRIDS) DESIGN FOR LWBR

(LWBR Development Program)

K. D. Richardson

Contract No. EY-76-C-11-0014

February 1979

\section{Printed in the United States of America Available from tho \\ National Technical Information Service \\ U. S. Department of Commerce $5285^{\circ}$ Port Royal Road \\ Springfield, Virginia 22151}

This report was prepared as an accoutit of work sponsored by the United States Govemment. Neither the United States nor the United States Department of Energy, nor any of their employees, nor any of their contractors, subcontractors, or their employees, makes any warranty, express or implied, or assumes any legal liability of responsibility for the accuracy, completeness or usefulness of any informstion, apparatus, product or process disclosed, or represents that its use would not infringe privately owned rights.

\section{NOTE}

This document is an interim memorandum prepared primarily for internal reference and does not represent a final expression of the opinion of Westinghouse. When this memorandum is distributed externally, it is with the express understanding that Westinghouse makes no representation as' to completcness, accuracy, or usability of information contained thereir.

BETTIS ATOMIC POWER LABORATORY

WE'ST MIFFLIN, PENNSYLVANIA

Operated for the U. S. Department of Energy by WESTINGHOUSE ELECTRIC CORPORATION 


\section{NOTICE}

This report was prepared as an account of work sponsored by the United states Government. Neither the United States, nor the United States Department of Energy nor any of their employees, nor any of their contractors, subcontractors, or their employees; makes any warranty, expressed or implied, or ..ssumes any legal liability or responsibility for...the accuracy, completeness or usefulness of any information, apparatus, product, or process disclosed, or represents that its use would not infringe privately owned rights. 
FOREWORD

The Shippingport Atomic Power Station located in Shippingport, Pennsylvania was the first large-scale, central-station nuclear power plant in the United States and the first plant of such size in the world operated solely to produce electric power. This program was started in 1953 to confirm the practical application of nuclear power for large-scale electric power generation. It has provided much of the technology being used for design and operation of the commercial, central-station nuclear power plants now in use.

Subsequent to development and successful operation of the Pressurized Water Reactor in the: DOE-owned reactor plant at the Shippingport Atomic Power Station, the Atomic Energy Commission in 1965 undertook a research and development program to design and build a Light water Breeder Reactor core for operation in the Shippingport Station.

The objective of the Light Water Breeder Reactor (LWBR) program has been to develop a technology that would significantly improve the utilization of the nation's nuclear fuel resources employing the well-established water reactor technology. To achieve this objective, work has been directed toward analysis, design, component tests, and fabrication of a water-cooled, thorium oxide fuel cycle breeder reactor for installation and operation at the Shippingport Station. The LWBR core started operation in the Shippingport Station in the Fall of 1977 and is expected to be operated for about 3 to 4 years. At the end of this period, the core will be removed and the spent fuel shipped to the Naval Reactors Expended Core Facility for a detailed examination to verify core performance including an evaluation of breeding characteristics.

In 1976, with fabrication of the Shippingport LWBR core nearing completion, the Energy Research and Development Administration established the Advanced Water Breeder Applications (AWBA) program to develop and disseminate technical information which would assist U. S. industry in evaluating the LWBR concept for commercial-scale applications. The program will explore some of the problems that would be faced by industry in adapting technology confirmed in the LWBR program. Information to be developed includes concepts for commercial-scale prebreeder cores which would produce uranium-233 for light water breeder cores while producing electric power, improvements for breeder cores based on the technology developed to fabricate and operate the Shippingport LWBR core, and other information and technology to aid in evaluating commercial-scale application of the LWBR concept. 


\section{FOREWORD (Cont)}

All three development programs (Pressurized Water Reactor, Light Water Breeder Reactor, and Advanced Water Breeder Applications) have been administered by the Division of Naval Reactors with the goal of developing practical improvements in the utilization of nuclear fuel resources for generation of electrical energy using water-cooled nuclear reactors.

Technical information developed under the Shippingport, LWBR, and AWBA programs has been and will continue to be published in technical memoranda, one of which is this present report. 
I. INTRODUCTION ·

A. The Light Water Breeder Reactor 1

B. Function of the LWBR Fuel Rod Support System 2

II. FEATURES OF THE LWBR GRID DESIGN 3

A. Description of the Support Structures

C. Fabrication 10

D. Springs and Dimples 11

$\begin{array}{ll}\text { E. Attachment Members } & 18\end{array}$

III. COMPARISON TO COMMERCIAL REACTOR GRID SYSTEMS 21

$\begin{array}{lll}\text { ACKNOWLEDGEMENTS } & 24\end{array}$

$\begin{array}{lr}\text { REFERENCES } & 24\end{array}$

APPENDIX A - GENERAL DESIGN CONSIDERATIONS · A-I

APPENDIX B - STRUCTURAL ANALYSIS METHODS AND GRID LOADING CONDITIONS B-I

APPENDIX C - ROD-TO-GRID CLEARANCES (PROXIMITY) C-I

APPENDIX D - MATERIAL PROPERTIES D D

APPENDIX E - SUMMARY OF STRUCTURAL TESTS IN SUPPORT OF THE GRID DESIGN E-I

APPENDIX F - SPRING FOLLOW. . . F-1

LIST OF TABLES

Table

$\underline{\text { Title }}$

$\underline{\text { Page }}$

1 Grid Axial Spacing $\quad \cdot 26$

2 Compositional Limits of AM-350 2\%

3 Mechanical Properties and Stress Iimits of AM-350 Sheet, 28 Bar, Wire, and Ni-30Cr-10Si Brazement Used in AM-350 Grids

4. As-Manufactured Grid Cell Spring Force Requirements 29

5 Minimum Spring Deflection Requirements at 30 Beginning-of-Life 
6 Grid Design Comparison

A-1 General Grid Design Considerations A-1

B-1 Seismic Shock Loads Per Grid B-ll

C-1 Blanket-Rod-to-Grid Clearance Reductions Under Worst C-5 Case Conditions

C-2 Comparison of Nominal Available Clearances and C-7 Reductions Under Worst Case Conditions

C-3 Comparison of Design Proximity Requirements and Worst C-8 Case Clearance Reductions

D-1 Mechanical Property Design Limits for AM-350 Material D-6 Used in the LWBR Grids

E-1 Summary of Grid Structural Tests . E-2

E-2 Grid Fatigue Test Summary $\quad$ E-7

E-3 Blanket Grid Connector Fatigue Test Summary E-8

E-4 Ultimate Load Test Summary E-9

LIST OF FIGURES

Figure

$\perp \quad$ LWBK Keactor

$2 \quad$ LWBR Core Cross Section

3 LWBR Seed Rod Support Grid

4 LWBR Blanket Type I Rod Support Grid

5 LWBR Blanket Type II Rod Support Grid

6 LWBR Blanket Type III Rod Support Grid

7 LWBR Reflector Type IV Rod Support Grid

8 LWER Reflector Type V Rod Support Crid

9 Typical LWBR Blanket Rod Support Grid
Pace

34

35

36

37

38

39

40

41

42 
10 Typical LWBR Seed Rod Support Grid

11. LWBR Seed Grid Components

13 LWBR Reflector Grid Components

14 LWBR Seed Module Assembly

16 LWBR Reflector Type IV Module Assembly

17 Percent Relaxation versus Fast Fluence for of AM-350 Sheet as a Function of Weight Percent Carbon

AM-350 Grid Carbon Content as a f'unction of Sheet Thickness and Wet-Hydrogen Decarburization Time

21 Typical Blanket Grid Spring Force-Deflection Curves for Several Spring Arch Heights

29. Typical Dimple Panel Section of a Seed Grid 3-Sided Component

30 Typical Dimple Panel Section of a Blanket Grid 3-Sided Component 
31 Cross-Sectional Views Through Grid Dimples

32 Grid-to-Guide Tube Connection

A-1 Loss in Spring Deflection Due to Fuel Rod Diametral A-8

A-2 Loss in Spring Deflection as a Result of Fuel Rod

A-9 Cladding Grooving

$A-10$

A-4 Fuel Rod Cladding Wear Spot Configurations A-11

A-5 Reduction in Rod-to-Grid Clearance and Loss in Spring A-12 Follow as a hesult of Fuel Rod Wcar

B-1 Contributions to Grid Stress Cycle B-12

B-2 Fatigue Life of Irradiated AM-350 Brazed Closed . B-13

Curl Hinge Joints

C-1 Identification of Grid Panel Numbering Scheme C-9

D-1 Room Temperature and 600F Tensile Properties of AM-350 D-7 Sheet as a Function of Weight Percent Carbon

D-2 Irradiated and Nonirradiated Shear Strength of AM-350 D-8 Wirc

D-3 Tensile and Elongation Properties of Two AM-350 Bar Heats D-9

D-4 AM-350 Nonirradiated Sheet Stress Versus Strain, D-1U Lower Chemistry

D-5 AM-350 Nonirradiated Sheet Stress Versus Strain, D-10 Nominal Chemistry

D-6 Ultimate 'l'ensile strength of' Alv-350 sheet as a D-ij Function of Neutron Radiation

D-7 $\quad 0.2$ Percent Yield Strength of AM-350 Sheet as a D-1l Function of Neutron Radiation

D-8 Corrosion Rates for AM-350 Sheet Material of Reference D-12 Heat Treatment and Chemistry

D-9 Thermally-Induced Stress Relaxation of AM-350 D-13 
D-10 Dependence of Radiation-Induced Stress Relaxation on

D-14

F-1 Carbon and Nitrogen Content of AM-350

$\mathrm{F}-7$ During an EFPH Time Interval 
Design features of the fuel rod support system (grids) for the Light Water Breeder Reactor (LWBR) installed in the Shippingport Atomic Power Station, Shippingport, Pennsylvania are described. The grids are fabricated from AM-350 stainless steel and provide lateral support of the fuel rods in the three regions (seed, blanket, and reflector) of the reactor. A comparison is made of the LWBR grids, whose cells are arranged in triangular-pitched arrays, with rod support systems employed in commercial light water reactors. Contributions of the various factors influencing the grid design, the reasons for selection of AM-350 as the grid material, and a description of the tests supporting the grid design are presented in appendices.

\section{SUMMARY OF THE FUEL ROD SUPPORT SYSTFM (GRIDS) DESIGN FOR LWBR}

(LWBR Development Program)

\section{K. D. Richardson}

\section{INTRODUCTION}

\section{A. The Light Water Breeder Reactor}

The design of a breeder reactor for a light water system imposes requirements on the fuel elements and support grids that are related to the neutron spectrum and the need to minimize parasitic capture of neutrons. One of the requirements for breeding is that the core have a high ratio of fuel-to-water, which results in closer fuel rod spacing than in current PWR designs. The close spacing reduces neutron capture by the water and maintains the hard neutron spectrum needed for breeding in light water. In the LWBR core, this is achieved by placing the fuel, which is in the form of cylindrically-shaped ceramic fuel pellets, into tubes whose ends are capped and sealed by welding. The tubes are made of Zircaloy 4 which has a low cross section for capturing neutrons. The low water content is obtained by placing the fuel rods in a close-packed, triangular pitch with rod-to-rod spacing of about $0.060 \mathrm{inch}$. This arrangement is significantly tighter than commercial light water reactors in which rods are generally located in a square-pitched lattice of about 0.120 inch rod-to-rod spacing.

Longitudinal and cross-sectional views of the core are displayed in Figures 1 and 2, respectively. As shown, the LWBR core consists of 12 hexagonal module assemblies arranged in a symretric array in the central region, surrounded 
by a reflector region containing 15 module assemblies. Each of the 12 hexagonal modules contains a central axially movable, hexagonal seed region surrounded by a stationary annular, hexagonal blanket region as shown in Figure 2. Each of the seed, blanket, and reflector modules contains a lattice of fuel rods, approximately 10 feet long, arranged in the triangular pitch pattern. The seed is made up of fuel rods of 0.306 -inch (nominal) diameter. The blanket fuel rods are of two diameters: regular or standard blanket rods are 0.572-inch diameter; power-flattening blanket rods (used for core power distribution reasons unique to this small core application) are:0.527-inch diameter. The reflector regions contain rods of 0.832 -inch diameter. Each fuel rod is attached at one end to a support plate, thus providing axial support. About half of the rods are top-mounted, half are bottom-mounted.

The mechanical design and operating environment of this core are deșcribed in greater detail in Reference 1 .

B. Function of the LWBR Fuel Rod Support System

Cylindrical fuel rods undergo certain dimensional changes during exposure to irradiation. The rods increase in length and both decrease and increase in diameter during core life because of such et'tectets as: Irradaullun-induced Zircaloy growth, which is a function of fast neutron fluence; clad diameter shrinkage under external coolant pressure (including fast neutron flux-enhanced creep of the cladding); and clad elongation and diameter increase caused by interaction with the fuel pellets which increase in diameter due to sulda dul gaseous fission products. In addition, power and fast flux gradienls (both radially across a fuel rod diameter and axially along the rod length) can affect the fuel rod contour. These conditions can cause the fuel rods to bow - a major concern in the LWBR design because of the close rod-to-rod spacing.

Flnw-induced vibration of the closely spaced rods was also of concern. This vibration can cause excessive fuel rod cladding wear, thus compromising cladding integrity. 
A lateral support structure was therefore necessary to minimize fuel rod bow and vibration while accommodating the effects of the dimensional changes (elongation and diametral changes). More specifically, the fuel rod support structure was needed to perform the following functions:

1. Maintain the position of each fuel rod in a manner which satisfies the nuclear and heat transfer requirements of the core; that is, maintain the fuel rods in a tight, yet coolable, lattice spacing while minimizing the hydraulic pressure drop across the support structure.

2. Maintain fuel rod positions to minimize rod-to-structure contact except at points designed to operate with contacts, that is, the spring and dimple contact points.

3. Provide sufficient support along the length of the rods to minimize bow due to thermal gradients, flux gradients, and so forth, while simultaneously minimizing the axial thrust which can also induce fuel rod.bow.

4. Minimize vibration-induced fuel rod clad wear by maintaining a positive force to keep the fuel rod seated against support structure contact points (dimples).

5. Perform the above functions in a manner which minimizes parasitic capture of neutrons in the support structure.

A more detailed description of the core requirements which influenced the design of the fuel rod support system is presented in Appendix A. The fuel rod support system developed to satisfy these requirements is described in this report.

II. FEATURES OF THE LWBR GRID DESIGN

\section{A. Description of the Support Structures}

The fuel rod support structures developed for use in the LWBR core were brazed grid arrays of AM-350, a type of stainless steel. Each grid array was composed of several hundred uniformly-sized, hexagonally-shaped cells. Three basic types of grids were developed, corresponding to the three types of module assemblies in this core. These were:

1. A hexäginally-shaped seed grid - Higure 3 
2. Three sizes of hexagonally-shaped blanket grids:

Type I - Figure 4

Type II - Figure 5

Type III - Figure 6

3. Two sizes of reflector grids:

A pentagonal grid (Type IV) - Figure 7

A trapezoidal grid (Type V) - Figure 8.

Hexagonally-shaped cells were a natural outgrowth of the close-packed, triangular pitch array required for breeding purposes and were advantageous, compared to grids having square cells, as a more uniform rod-to-grid structure spacing was achieved. Lateral positioning of each fuel rod was provided by a flexible support spring located at the mid-height of one of the six cell walls, and by either two (blanket and reflector grid cells) or four (seed grid cells) rigid reaction dimples located 120 degrees circunferentially from the spring. The spring and dimple orientations within the hexagonal cells are illustrated in Figure 9 (blanket) and Figure 10 (seed).

The grids were assembled from sheet metal stampings, wire pins, and connecting members machined from bar stock (Figures 11, 12, and 13). A basic three-sided "half-hex" component, whose sides are at 60 degree angles, was used to form one-half of the hexagonal cell. (see Figure 9). For geometry reasons stamped and formed components of other than three sides were necessary to complete the overall grid design.

The grid components contain hinges at the intersection of each side which mate with hinges of adjoining components. A wire hinge pin was inserted through the mating hinges to mechanically lock the stamped components. The pins are captured by heading at one end and mechanically crimping the opposite end after. insertion in the hinges.

Redundant joining methods were used to prevent components from coming loose during core operation, causing possible blockage of the water channel or loss of control of rod positions. The mechanical interlocking of components through the use of pinned hinges provided une llellud. Wrazing the pins to the hingev furnished the second joining method. 
The pins were brazed to hinges over the full pin length (except for a few locations in blanket and reflector grids for which that was not practical due to manufacturing considerations) so that flexibility of dimple panels was reduced. The brazing operation also imparted dimensional stability and rotational rigidity to the grids. Welding was not used because it is difficult to hold dimensional tolerances during welding and heat treatment of the "hinge-joint" type grid. In addition; the brazing operation could be combined with the thermal treatment necessary to develop high strength in the AM-350 grid material.

The use of stamped and formed components facilitated ease of assembly and allowed use of material thinner than that of machined components. However, the connecting members, which transmit grid loads to the structures supporting the grids, were machined from bar stock to provide components capable of carrying the increased loads. Each connecting member replaced one or two fuel rods at specific locations in the peripheral row to attach the grid to the external support structures without making the grid larger than necessary.

In the blanket grids, reinforced sheet metal tab connections extending about two inches below the grid were used to connect the internal boundary endplates (Figure 12) to the guide tube. The latter is a hexagonally-shaped tubular structure of Zircaloy which serves both as a guide for the movable seed assembly and as an internal supporting structure for the blanket grids.

For external support, the grids were attached to long, slender support posts, which in turn were attached to support plates located at the top and bottom of each module. In the seed and reflector assemblies, the support posts were also attached at specific elevations to Zircaloy shells which encase these modules for flow distribution control. Blanket modules do not have external shells; however, they do have a Zircaloy internal shell (a guide tube). The grid attachments are schematically illustrated in Figures 14 (seed), 15 (blanket), and 16 (reflector).

Corrugated boundary straps and flat endplates (Figures 11, 12, and 13) converted the peripheral row of hexagonally-shaped cells into a flat boundary surface. These components were used to keep the grids to a maximum overall. dimension without loss of a row of rods. The flat end plates were spot welded (electrical resistance) to the boundary straps to accept the structural loads 
which in turn were transmitted through the end plates to the connectors. Welding of the end plates to the boundary straps was preferred over brazing as the latter was found to cause a rippling distortion of the end plate surface with . consequent loss in control of boundary dimensions.

Fuel rod bowing and vibrational concerns were satisfied by optimizing placement of grids at specified elevations along the approximately l0-foot long rods. While additional grids would reduce the magnitude of bow between levels and potentially reduce the amplitude of vibration, a penalty would be exacted on the breeding performance. The number of fuel rod support grids in any type module assembly was therefore a compromise between rod bowing concerns, for which additional grids are desirable, and breeding concerns, for which a minimum number of grids is desirable. The number of grids used was that minimum number which limited fuel rod bowing such that the thermal-hydraulic limits and minimum rod-to-rod clearances were satisfied throughout core life. There are nine grid elevations in the seed assemblies (Figure 14), eight grid elevations in the blanket assemblies (Figure 15), and six grid elevations in the reflector assemblies (Figure 16). The number of grid elevations differs among the three module assemblies because the fuel rod diameters (and hence the rod stiffnesses) and the environmental conditions (power, flux) differ for each type assembly.

Axial spacing between grids was made nonuniform to optimize the fuel rod bowing restraint and to eliminate amplification of rod vibration due to coincidence of the span lengths with the rod natural frequency of vibration. The span lengths are listed in Table 1.

\section{B. Grid Material}

The breeding objective required the use of a structural material having a neutron capture cross section as low as possible. While the zirconium-based alloys have low neutron capture cross sections, they experience a high level of stress relaxation during irradiation. Figure 17 graphically portrays the total stress relaxation (the loss in spring force) at essentially operating temperature as a function of fast neutron fluence and exposure time. Since there is a concern regarding flow-induced vibratory cladding wear and fuel rod bowing under conditions where the rod would be loose in the grid cell due to total relaxation of the spring force, alternate materials were evaluated. 
Tests of the major candidate materials (Zircaloy-4, NiCrFe Alloy 718 and AM-350) revealed that AM-350, a semi-austenitic, precipitation-hardening stainless steel, having the compositional limits listed in Table 2 , experiences a much smaller amount of stress relaxation (Figure 17). In addition, it exhibited a neutron capture cross section among the lowest of any of the non-zirconium materials tested. AM-350 exhibited high strength at operating temperature (Figure 18) and, therefore, could be made quite thin in cross section to further enhance the breeding capability. This permitted the use of thin sheet metal components for the grids, namely, 0.0135 inch in the seed, 0.014 inch in the blanket, and 0.015 and 0.018 inch in the reflector grids. The different thicknesses were established, basically, as the minimum thickness from which the required spring force could be developed to prevent unacceptable fuel rod bow and vibratory wear, since the required spring force was dependent upon the fuel rod stiffness. AM-350 was also found to exhibit adequate fatigue margin under the cyclic loading conditions imposed on the grids during transient core operation (described more fully in Appendix E).

In addition to AM-350 sheet components, the pins and external connectors were made from AM-350 wire and bar stock, respectively. The mechanical properties and design stress limits of the AM-350 grid material used in the structural analysis of the LWBR. grid design are presented in Table 3. The structural analysis and grid loading conditions are described in Appendix $B$.

To confirm its acceptability in the LWBR core environment, AM-350 underwent many corrosion tests. The corrosion resistance was determined to be a function of material chemistry and heat treatment. By reducing the carbon content a relatively small amount, from a nominal of 0.08 weight percent to 0.04 weight percent in a decarburization thermal treatment (Reference 2), corrosion resistance was enhanced. The lower carbon content eliminated carbide precipitates which developed at grain boundaries. In this decarburized condition, AM-350 was determined to be highly resistant to both intergranular and intragranular corrosion in the LWBR environment. However, AM-350 of higher carbon levels and different heat treatment was susceptible in varying degrees to these two types of corrosion processes. AM-350 bar material, used in the grid connectors, was obtained with lower initial carbon content since the heavier cross sections were not readily reduced in carbon content during the decarburization cycle. 
In addition to improving the corrosion resistance, the decarburization reduced the rate of stress relaxation of the spring. Data indicated that the radiation-induced (in-pile) stress relaxation of AM-350 decreased by. about 4 percent for every 0.01 weight percent (w/O) reduction in carbon content. Thus, a reduction in the carbon content rrom a nominal of $0.08 \mathrm{w} / \mathrm{o}$ to $0.04 \mathrm{w} / \mathrm{o}$ resulted in a beneficial reduction in the stress relaxation of about 16 percent. A reduction in nitrogen content was found to have a similar, though less pronounced, effect on stress relaxation; that is, a reduction of $0.01 \mathrm{w} / 0$ nitrogen decreased the stress relaxation by about 2.5 percent. Other things being equal, it is, therefore, more desirable to use grids having carbon and nitrogen contents at the lower end of their respective limits in the higher neutron flux levels of the module assemblies.

No evidence of stress corrosion cracking was observed, even on highly strained AM-350 specimen's, under room temperature test conditions. Tests alsc confirmed that the solubility limit of hydrogen in AM-3bU having a norma 1 corrosion prefilm, is insufficient to cause hydrogen stress corrosion cracking in the oeprating temperature environment. AM-350 was also resistant to crackirg in a potassium tetraborate solution which was considered as a potential emergency poison solution in the reactor.

The general steady-state corrosion rate for AM-350 of the reference chemistry, heat treatment, and reactor environment was found to be quite low; that is, it.was equivalent to an average metal loss of about 0.13 mil over 30,000 hours at operating temperature. Additional tests showed that, regardless of surface condition, the galvanic coupling of Zircaloy-4 and AM-350 had little effect on the normal corrosion behavior of either material in the reactor coolant at operating temperatures.

The grid mechanical arrangement and material were determined to be resistant to crud buildup. In fast neutron flux locations, all grid surfaces of test grids in long rod bundles were observed to be bright and clean with no crud buildup. In out-of-flux locations the internal grid surfaces are again observed to be bright and clean, while the external surfaces (boundary surtaces) had an acceptable crud layer of 1 to 2 mils thickness. 
AM-350 was determined to be dimensionally stable in its intended application during core lifetime. Dimple positions, as indicated by cell-to-cell pitch dimensions, remained stable, changing less than 1 mil. Overall grid cell distortions were not observed. Further, differential growth could not be detected between the spring material and the composite brazed hinge pin material. Hence, distortion due to growth differential was not a problem.

Examination of grids at rod contact points in numerous tests consistently failed to disclose any measurable wear of the AM-350 grid material. This confirmed that wear of the AM-350 grid material was negligible and of no concern. (One test, however, did indicate that improperly prepared Zircaloy cladding, that which has been flash pickled only prior to corrosion prefilming, could wear the AM-350 grid reaction dimples.)

The choice of AM-350 stalnless steel as the grid material was advantageous with respect to forming the stamped hexagonal components. This material is essentially austenitic in the solution annealed condition as received from the supplier, having typically a yield strength of 60,000 psi and an elongation of 40 percent (at room temperature). As such it possessed the high ductility necessary for the intricate forming operations required of these components. During the stipulated thermal treatments following forming and assembly, the austenitic structure is transformed to martensite with a considerable increase in yield strength (to greater than $125,000 \mathrm{psi}$ at room temperature as shown in Figure 18). Thus, AM-350 provided a desirable combination of initial ductility and final high strength during core life.

A modified BNi-5 nickel-base brazing filler metal was developed at Bettis specifically for use with the AM-350 support grids. The filler metal, nominally 60 percent nickel, 30 percent chromium, 10 percent silicon, forms a two-phase microstructure with AM-350 when heated to a temperature of 2l00F. This brazing material has been shown to exhibit excellent corrosion resistance in the reference LWBR environment. Other commercially available brazing filler metals lower in chromium content corroded during testing due to the presence of a third chromium depleted phase. The corrosion behavior of this brazing filler metal is described in detail in Refeience ( 3 ). 
A more detailed description of the material properties of the AM-350 grid material is presented in Appendix $D$.

\section{Fabrication}

The AM-350 components were dimensioned to very tight stamping and forming tolerances to prevent stackup of of't-nominal dimensions ard, consequently, very large or very small overall grid dimensions. To account for the volumetric growth of AM-350: due to the austenite-to-martensite transformation during the thermal treatment, the initial dimensions of the stamped components were reduced hy 0.003 inch/inch in the longitudinal direction (parallel to the rolling direction), and $0.004 \mathrm{inch} / \mathrm{inch}$ in the transverse direction.

After cleaning, the components were assembled and, simultaneously, the brazing filler metal was applied to the hinge jolnts. The grids were vacuun brazed at $2100 F$, with relatively massive fixturing used to maintain grid dimensions during this thermal operation (Reference 4). A decarburization cycle in wet hydrogen gas (Reference 2) then reduced the nominal carbon content fromin 0.08 weight percent to 0.04 weight percent (Figure 19) to enhance resistance of the AM-350 material to corrosion. A subzero cooling treatmenl (three hours at -lOOF) maximized transformation of the austenite to martensite, while a final vacuum thermal operation (three hours at 1000F) tempered the martensite to provide increased ductility and enhanced corrosion resistance.

Mechanical adjustment of the dimples and springs was performed as required to "fine tune" the cell dimensions to meet deslgn requilemerits. The adjustmontc were performed prior to the final tempering cycle. 'l'his permitted somc relief of stresses imposed during the mechanical cold working operations. Thermal sizing of the blanket grids was performed during this same thermal tempering cycle to reduce overall grid boundary dimensions (both internal and external) to satisty design requirements.

Breeding. concerns were a major factor in establishing the nominal cell-tocell pitch dimensions ( 0.369 inch in the seed, 0.630 inch in the blanket, and 0.901 inch in the reflector). Control of these dimensions (a tolerance of $+0.012,-0.007$ inch was specified for all grid types) was necessary to prevent either excessive water gaps, which scavenge neutrons needed for breeding purposes, or inadequate water gaps between adjacent fuel rods, which could lead to 
elevated clad temperatures. Likewise, rod-to-grid clearance limits were established to minimize cladding hot spots and wear due to contact of the rod with the grid panels (discussed in detail in. Appendix $C$ ). To meet these pitch and rod-to-grid clearance requirements, cell dimensional inspection and adjustment of dimples were performed during manufacturing.

All grid connectors. were machined after the thermal treatments so that the connector lug holes, through which the post-to-connector bolt was inserted could be positioned more precisely. This procedure was specified to minimize mismatch strains in both the grids and their supporting structures, thus accounting for differences in overall boundary dimensions from grid to grid. An additional procedure was necessary to accommodate differences in overall grid sizes for the blanket grids.. Special "machining pads" were specified at the top and bottom of the original components. Custom machining of these pads after the thermal treatments permitted more accurate positioning of the support post.

\section{Springs and Dimples}

The spring design employed in all LWBR grids was a modified leaf spring f'ixed at both ends and parallel to the rod axis, as shown in Figures 9 and 10. The fixed ends were made integral with the sheet metal component, providing foundations necessary to develop the spring force and to transmit spring loads to adjacent components and, eventually, to the grid connectors. To minimize the contact area with the fuel rod, a cylindrical dimple having an axis normal to the length of the spring was located intermediate the spring foundations. This spring dimple was helpful in keeping fuel rod cladding temperatures below the thermal limits established to prevent accelerated corrosion and hydriding of the Zj.rcaloy cladding (Reference 5).

The small diameter ( 0.306 inch) seed fuel rods required a "clamped" spring and dimple combination to minimize fuel rod bowing of these very flexible rods. The seed grid employed four reaction dimples, two near the top and two near the bottom, with the spring at the axial center of the cell (see Figure 10). The dimples were separated by 1.1 inches, the maximum separation possible consistant with structural adequacy, to decrease the spring requirement. The relatively large diameter blanket and reflector fuel rods, beinf, mucl stiffer, were "pinned" at the axial center of each grid cell by placing the two dimples at the same 
axial elevation as the spring. A clamped system would have required very high spring forces to seat the fuel rod against two elevations of dimples in the blanket and reflector grids, thus increasing the axial thrust load on the rods.

Elastic deflection of the spring results in a force normal to the rod axis. This force, if large enough to overcome fuel rod bowing and rod and grid installation misalignment forces, will seat the fuel rod against the opposing fixed reaction dimples. Because many factors affect the amount of spring deflection, a spring having a flat force deflection curve (spring rate decreases with deflection) was desirable; that is, the spring force should experience as little change as possible over a broad range of elastic deflection. The spring design and dimensions, summarized in Figure 20, were selected to provide this characteristic. Figure 21 depicts a typical set of force-deflection curves for the springs, using the data for blanket springs. It is observed that the spring force is directly dependent upon the "arch height" (see H'igure '2U t'or det'inition). 'The selection of' an 0.032-inch nominal arch height for the blanket springs provided a reasonably broad deflection range (approximately 0.030 inch) for the reference spring design.

Four phenomena occur during reactor operation which result in a reduction in the ability of the spring to hold the fuel rod securely against the dimples. These phenomena are:

1. Stress relaxation, both thermal and radiation-enhanced, results in a direct reduction in the soring force because some fraction of the spring deflection is converted from elastic to plastic. Typical changes in the spring force due to these phenomena are shown in Figure 22, again using data from the blanket grids.

2. A reduction in the amount of spring deflection occurs because of such effects as fuel rod diametral shrinkage, cladding wear, and grid corrosion. Note that recovery of the dimple panel deflection represents a gain in spring deflection. The magnitude of these deflection losses is shown in Figure 23.

3. Changes in the shape of the spring-force deflection curve occur due to fast fluence accumulation. This results in a lower spring force for a giver deflection, as depicted in Figure 24 for blanket grid springs. 
4. Fuel rod bow, acting in a direction opposite to that of the spring force, effectively reduces the spring force. This phenomenon was of particular concern in the apex region of Type IV reflector grids.

Initially, therefore, the spring force and deflection had to be set sufficiently high to accommodate these expected changes, thus assuring adequate spring force at end-of-life. Appendix F presents in detail the method used to evaluate this "spring follow" ability. Unnecessarily high spring forces, on the other hand, augment axial thrust bowing of the fuel rods, thus reducing rod-to-rod clearances. Correspondingly, unnecessarily high spring deflection results in excessive tensile strains in the spring and/or excessive deflection of the back surface of the spring into the adjacent cell. Maximum spring force and deflection limits, as tell as minimum limits, were established to prevent these undesirable conditions. Table 4 lists the spring force limits established for the LWBR grids; Table 5 lists the minimum spring deflection requirements. In relation to the maximum spring deflection, a limit of 1.2 percent maximum tensile strain (about one-third the fracture strain) was established for these AM-350 springs to assure structural integrity and to preclude stress corrosion failure.

While the LWBR grid springs were stable with respect to spring deflection (that is, they would not snap through into the adjacent cell), the back of the spring could potentially intrude into that adjacent cell. The intrusion may be symmetric (Figure 25) if both sloping sides of the spring move uniformly toward the adjacent cell. If the two sloping sides have different slopes, however, deflection of the spring usually results in a moment tending to rotate the spring dimple, leading to an asymmetric response (Figure 26).

Excessive spring intrusion is undesirable for two reasons. First, if the spring makes contact with the rod in the adjacent cell with sufficient force, the rod could be lifted off its fixed dimples. The rod is then supported between opposing springs having low stiffness. Potentially, this could result in vibration-induced fretting of the fuel rod cladding and increased fuel rod bowing. Second, the additional area of contact between the fuel rod and intruding spring may result in local cladding hot spots that exceed the temperature limits assuciated with spalling corrosion and hydriding of the Zircaloy cladding. The springs were designed to minimize this type of intrusion. 
Studies of actual grids revealed that the spring intrusion response was an approximately linear function of spring arch height for a given deflection (Figure 27). The symmetric intrusion decreased as the arch height increased; whereas the asymmetric intrusion increased with increased arch height. The total intrusion response also shown in Figure 27 , decreased with an increase in arch height, but at a lower rate than the symmetric intrusion.

This spring intrusion problem was resolved by two means:

1. For each spring type, the arch height was made as high as possible, consistent with the spring force and deflection restraints noted earlier.

2. The intrusion was measured in each cell of each grid during manufacturing. Where the distance between the intruding spring and the adjacent fuel rod violated limits established to compensate for possible rod movement during core operation, the intruding spring or the fuel rod positions were mechanically adjusted to increase this distance.

The higher spring force requirements of the blanket and reflector grids (Table 4), as compared to the seed grids, were obtained by

1. Increasing the spring width.

2. Increasing the material thickness.

3. Increasing the arch height.

The resulting values are tabulated in Figure 20. The length of the springs was established as the minimum length (to minimize material volume for breeding enhancement) which would maintain the tensile stresses below the 1.2 percent limit while providing a broad def'lection range f'or increased manutacturing capability. The spring length including the foundations (see Figure 20) thus established the height of the grids.

Because of the difficulty of directly measuring spring force and deflection on the coordinate measuring machines used to inspect grid cell dimensions, two other cell attributes capable of being measured on this equipment were used. The distance from the cell center to the spring dimple in its free, or undeflected, position (known as the Free Spring Position, FSP) was measured for each cell. The Total Spring Height (TSH) of the spring dimple above its foundation (see Figure 20) was similarly measured. Tests correlated these two parameters 
with spring force and deflection, allowing these parameters to define an "envelope" of acceptable spring tolerances. A typical "tolerance envelope" (for seed grid springs) is show in Figure 28. Acceptable combinations of Free Spring Position and Total Spring Height are located within the envelope. Similar tolerance envelopes were developed for blanket and reflector grid springs, the shapes of which were modified to account for differences in spring characteristics due to differences in arch height, spring width, and thickness.

For the blanket and reflector grids, a more limiting requirement representing the maximum permitted intrusion of the spring into the adjacent cell replaced the 1.2 percent maximum strain limit at the bottom of the envelope. Measurement with a special force probe developed subsequent to fabrication of the seed and reflector grids, further verified spring forces for the blanket grids.

A common spring design was specified in both the standard blanket and power-flattening blanket rod regions, even though the rod diameters in the latter regions were 0.045 inch smaller. The smaller diameter rods were centered in their cells by two means:

1. The dimple heights were increased by half this amount; that is, they were increased by 0.022 inch.

2. The spring panel was offset by 0.023 inch toward the center of the cell.

Thus the spring heights and therefore spring characteristics were identical in both regions. This eliminated the high strains which would have resulted had the power-flattening cell springs been increased in height to compensate for the smaller diameter rods.

Several special case cells required modification of the "Basis" spring design in the reflector grids.

1. Seven cells in the apex of the Type IV grids, which are at a higher power level, required higher spring forces to minimize the increased amount of fuel rod.bowing.

2. Minimal space availability on certain boundary straps in the Type IV and Type $V$ grids necessitated a reduced width design in two cells. 
The spring dimensions for these reflector springs were specified to satisfy these special cases (Figure 20).

The fixed dimples were designed to react the spring loads in a controlled manner such that the rod-to-rod clearance limits were always maintained. The types and orientation of the dimples are shown in Figures 9 and 10 for blanket and seed grids, respectively; reflector grid dimples were of the same basic design as the blanket grid dimples and therefore are not shown. Each dimple panel was located 120 degrees circumferentially from the other dimple panel and from the spring panel. This orientation was a lugical consequence of thc hexagonal cells and was advantageous in that any ovality of the fuel rod would not affect spring deflection and hence spring force (Reference 6). Such an orientation was desirable for the blanket fuel rods which initially form an elliptical shape as the cladding deforms onto the fuel pellets under system pressure and neutron irradiation. The 120 degrec orientation, however, does exact a penalty on spring deflection tor fuel rods which experience diametral shrinkage (as do most of the LWBR fuel rods). For these rods, the loss in spring deflection is equal to 1.5 times the reduction in rod diameter.

Typical dimple panel portions of three-sided "half-hex" grid components are illustrated in Figures 29 and 30. The seed panel (Figure 29) has two cylindrical dimples, one near each end of the panel, whereas the blanket (and reflector) panel contains one cylindrical dimple located atop a truncated pyramid at the axial center. Although spherscal almples cuuld huve been nore readily pressed into the panels, dimples of this shape were not specified berause of the increased rod cladding wear, less positive rod position control, and greater difficulty in adjustment lor spherical almples ver"sus cylindrical dimples. Similarly, dimples having flat contact surfaces were not employed as they would have made contact with a larger area of the fuel rod, resulting in higher cladding temperatures. Flat dimples are less stif'f' than cylindrical dimples and would have reduced the ability to maintain fuel rod positions. A dimple having a cylindrical contact surface, with a radius of curvature of $0.100 \mathrm{inch}$, was therefore specified as it was determined to be desirable for rod heat transfer reasons. 
The dimple panel sections for the blanket and reflector grids (Figure 30) are much wider than for the seed, making these panels more flexible. The flexibility is further increased by the removal of material in the "window" areas, which were incorporated to reduce material volume to enhance the breeding potential. Truncated pyramidal foundations were added to increase the stiffness of the dimple panel, and thereby minimize cell instability. In the reflector grids, the 0.018-inch thick material also increased the panel stiffness over that of the 0.014 -inch thick blanket grid material. The 0.100 -inch radius cylindrical dimple was located on the truncated portion of the pyramid such that it extended 0.013 inch (blanket) and 0.015 inch (reflector) above the pyramid (shown in Figure 31). This combination of a raised cylindrical contact surface with a pyramidal f'oundation was determined to be thermally acceptable with respect to cladding temperatures, as well as beneficial for reducing cell flexibility.

The spring rate for these pyramidal dimples was quite high compared to the spring rate for the grid cell springs. For example, the blanket dimples had a spring rate of approximately 3 pounds per mil, or about ten times that of the cell springs. Furthermore, the deflection of the pyramidal dimple was absorbed with small (approximately 0.001 inch) panel deflection. Hence the pyramidaltype dimples contributed significantly to the reduction of cell flexibility.

Pyramidal dimple foundations were not specit'ied t'or the seed grids because of the very small dimple panel widths (0.213 inch versus 0.364 and 0.521 inch for the blanket and reflector grids, respectively). Formation of a pyramidal base would have resulted in material thinning and cracking and panel distortion due to the excessively steep sloping sides which would be required of a pyramid foundation. Additionally, the cylindrical dimple was several times as stiff as the total cell stiffness, so that increased dimple stiffness was not necessary.

The lateral intersection of the cylindrical dimple contact surface with the dimple panel (seed) or with the pyramidal base (blanket and reflector) was slotted before forming. This design characteristic was incorporated to

1. Prevent cracking during forming.

2. Reduce panel distortion during dimple forming.

3. Permit dimple height adjustment during fabrication to achieve cell dimensional requirements. 
The width of the cylindrical contact surface was made as wide as permitted by the physical dimensions of the panels to minimize contact of the sharp dimple edge with the fuel rod cladding. The seed and blanket dimple widths, however, could not be made "infinitely wide" relative to the rod diameter. In these grids, the dimple edges contact the cladding after a cladding wear depth of 0.002 or 0.003 inch is exceeded. The seed and blanket dimple edges were rolled over by 0.003-inch minimum (noted in Figure 31) to prevent sharp edges of the dimples from contacting the fuel rod cladding. The larger cell sizes of the reflector grids permitted the dimple widths to be extended to 0.085 inch (versus 0.040 inch and 0.050 inch for the seed and blanket dimples). Hence, rolled edges were not necessary for reflector dimples.

\section{H'. Attachment Members}

"Post connectors" (Figures.11, 12, and 13), which were brazed to the grid structure (Figures 3 through 8), provided the means of attachment of the grids to their supporting structures. Each connector had an integral lug section through which a hole was machined after heat treatment of the grid. An AM-350 bolt rigidly attached the connector to the Zircaloy support post (Figures 14 , 15, and 16) through the lug hole to more efficiently transmit loads between them and to eliminate hydraulically-induced vibration between the grid and shell.

specifying one connector per grid 'side minimized the number of connectors. However, an additional load-carrying connector was nëcessary for the long sides of the Types II and III blanket grids and the retlector grids. Connectors for the seed and reflector grids were located at the center of the grid sides. $\perp f^{\prime}$ the connectors were located at grid corners, manufacturing variations of the shells in the corner regions could result in assembly fitup (interference) problems. For the shell-less blanket modules, the connectors were placed at the grid corners to coincide with the support posts. These support posts served as wear pads to prevent module rotation and grid contact during core assembly.

In this respect, it was desirable to assure that the blanket support posts extended at least 0.005 inch beyond the outer surface of the blanket grids to act as wear pads, preventing two adjacent modules from coming into contact (and damaging the rods or grids). In contrast, a maximum boundary dimension of the blanket grid with its support post assembled was specified to be at least 0.060 inch less than the theoretical module envelope, thus providing sufficient 
clearance for module assembly into the core. As an aid to meeting these two criteria, "pads," against which the posts were positioned, were added as integral parts of the blanket connectors (Figure 12). These pads were simply sections of increased wall thickness at the top and bottom of the center wall. of the "side post connectors" and at the top and bottom of the two outer walls of the "corner post connectors." Custom machining of each pad after all other grid manufacturing operations had been completed, permitted attainment of these two necessary boundary criteria. It was not necessary to provide pads on the seed and reflector grid connectors to assure module-to-module clearance as these grids were contained within shells.

The connectors were brazed to the sheet metal grid components (including the flat end plates) using the same brazed hinge-pin joint method utilized for the sheet metal-to-sheet metal joints. Hinge curls were integrally machined in the connector block to entirely surround the pins and, thus, were more efficient in terms of load carrying capability than the sheet metal. hinge curls. The structural integrity of the connector-to-sheet metal joint was therefore limited by either the hinges of the attached sheet metal grid components or the hinge pins, rather than by the connector hinge curls. Since these connector hinge pins were the most highly loaded pins in the grids, it was desirable to provide them with a maximum amount of shear area. This was accomplished by entirely covering the hinge pins by either the machined connector hinges or the sheet metal hinge curls.

Where the connector hinge curl length exceeded about 0.300 inch, a braze reservoir slot was machined at the center of the long hinge curl. (See for example the two top and two bottom curls on the back view of the seed grid support post connector, Figure 1l.) Sufficient braze alloy slurry could thus be deposited prior to brazing to ensure a sound brazement along the entire length of these long hinge curls.

In the seed grids, two fuel rod locations were eliminated, without seriously affecting core performance, to provide enough space to accommodate a structurally adequate post, with the lug section at the axial grid centerline. Likewise, for the reflector posts the grid cells were large enough to provide a structurally adequate support post connection at the grid level with only one cell per post involved. This was not the case for blanket posts, however, for which breedirig 
requirements dictated that only one fuel rod per support post be eliminated. If the connector lug section were located at the axial grid level, the support post sidewalls would have been excessively reduced in thickness and the bending moments would have exceeded allowable stress limits of the lug section. For this reason, the lug sections in the blanket, connectors were located about 0.875 inch below the grid level (Figure 12). The lug sections were integrally attached to the connectors by means of a 0.060 -inch thick stem to provide some flexibility in this post-to-grid connection. To provide adequate resistance to buckling under axial compressive loading (during transient conditions), a design limit of 0.020 inch maximum offset of the lug section from a vertical position was specified. Mechanical testing of such connectors (Table E-3, Appendix E) confirmed that the compressive loa. requi red to buckle a conncctor was over 500 pounds (cold), whereas the maximum design load a cnnnertnr chnuld experience is about 208 pounds (cold, which is equivalent to 183 pounds at operating temperature).

Attachment of the internal boundary of the blanket grids to the guide tube required a flexible connection to accommodate assembly clearances and differential thermal expansion between the greater expanding AM-350 grid and the Zircaloy guide tube. This connection required that the internal boundaries be directly attached by a Zircaloy screw to the guide tube to minimize grid material volume and because space was not available for a bolt type connection. Although one connection per side would have been adequate (Table E. 4 of Appendix E), iwo screws per side were specified as a conservatism to assure that the screw threads were not overstressed.

'l'he internal boundaries could not be attached at the axial grid centerline since clearance was required between the screw head and the adjacent fuel rods. By extending the sheet metal of the internal boundary end plate component.s tin form "tabs" below the grid level, the attachment could be effected without the displacement of two fuel rods per side. The 0.014-inch thick tabs were reinforced by spot welding (electrical resistance) a 0.014-inch thick AM-350 strip to each tab. By locating the tabs (and 1119s) helow, rather than nhove thr erials, the tabs (and lugs) were normalıy in tension (rather than compression) as the assembly loads and nel steady-state operating loads were all upward on the grids. 
As noted in Figures 4, 5, and 6, the internal attachment tabs had an offset bend toward the center of the grid at a distance of about 0.70 inch below the grid level. This 0.049 -inch nominal offset accommodated the assembly clearances and the differential thermal expansion between the grid and guide tube. The grid to guide tube connection is schematically illustrated in Figure 32 . Note that the guide tube wall contained a 0.020 -inch deep relief area to provide additional clearance for the screw head (to the adjacent fuel rod). The guide tube wall had an additional 0.010-inch deep relief so that the grid tab would act as a spring when the screw was torqued down into this relief (lower sketch in Figure 32). This spring action provided additional preload to the screw such that sufficient preload was maintained even if the Zircaloy screw relaxed 100 percent prior to the end of core life.

Critical buckling loads of the tab, having an offset of the reference design noted above, were determined to be over 250 pounds (cold), whereas the maximum tab loads imposed during core operation were calculated to be only 91 pounds (cold). (See Table E.4 of Appendix E.) Compressive loading in the axial direction could result in a 0.006 -inch lateral deflection of the tab. This potential deflection was considered in assessing tab-to-rod clearances. These clearances were measured during assembly of the modules; where necessary to meet minimum clearance limits, the tab edges were rounded and/or filed.

A summary of the results of structural tests performed in support of the LWBR grids, including the attachment members, is presented in Appendix $\mathrm{E}$.

\section{COMPARISON TO COMMERCIAL REACTOR GRID SYSTEMS}

Table 6 presents a comparison of the major mechanical features for the LWBR grids and three typical commercial reactor grids, with each of the three LWBR grids (seed, blanket, and reflector) listed separately. The commercial reactors included in Table 6 are:

1. Westinghouse Electric's RESAR 414 (Reference 7).

2. Babcock \& Wilcox's Standard 205 (Reference 8)

3. Combustion Engineering's System 80 (Reference 9 ). 
Commercial light water reactor grids typically have a square lattice array with large rod-to-rod spacing relative to the LWBR grid.design. In the LWBR core, neutron economy required a close-packing of the fuel rods in a triangular pitch arrangement. Since each non-peripheral cell is surrounded by six other cells, forming each cell into a hexagonal configuration minimized cell wall widths.

Commercial reactors generally use Zircaloy-4 or NiCrFe Alloy 718 as the grid material. An alternate material, AM-350, was chosen as the LWBR grid material because of its lower stress relaxation behavior (Figure 17), relatively low neutron capture cross section, high strength, and good corrosion resistance.

In the commercial grid systems, long strips are often assembled in two perpendicular directions in an "egg crate" fashion and are welded or brazed at their intersections. In contrast, the TWBR grids were sompoced of individually stamped and formed sheet metal components (of mainly a three-sider "half-hex" shape) and machined connecting members which were assembled to form a single urit by two methods:

1. The intersections of each component were mechanically locked by insertion of pins through hinge joints.

2. The hinge joints were brazed together using a Ni-30Cr-10Si braze alloy.

LWBR grids are larger than commercial grids in overall dimensions. Commercial grids are generally square arrays of about 8 inches across flats. whereas LWBR grids vary f'rom 9.3 inches for the seed grids (across the flat. dimension) to greater than 19.2 inches for the largest blanket grids. These large grids were designed to be single units supporting all fuel rods in a given region. This concept minimized neutron ahanrhing structural matcrial which wulld ve necessary if the grids were subdivided into smaller units, each with their peripheral components, to be joined together during module assembly.

The number of fuel rods supported by each LWBR grid is about 0.7 to 2.7 lines the rumber of rods in commercial systems. Spacing between the fuel rods is about one-half that of commercial systems. Similarly, rod-to-grid clearances are also about one-half those of typical commercial systems. The pitch-to-fuel rod diameter ratios are larger in commercial reactors by about 10 to 20 percent. 
LWBR grid design parameters and axial spacing were specified to provide the required lateral control of the fuel rods, considering the contributions toward rod-to-rod contact and rod-to-grid panel contact throughout core life in these LWBR grids having closely-spaced fuel rods.

Similar to most commercial reactors, a system of flexible springs, which seats the rod against rigid dimple supports, supports and positions the LWBR fuel rods. Whereas commercial grids generally have two springs on two adjacent panels set at 90 degree angles with four dimples (two top and two bottom) on the opposite two panels, the LWBR system employs one spring with two dimple panels (containing one or two dimples each) set at 120 degrees circumferentially from the spring panel (Figures 9 and 10). The fuel rod diameters determined the type of dimple support. Multiple dimple levels similar to those in commercial reactors were specified for the more flexible seed rods to provide the built-in stiffness needed to control fuel rod bow and vibration. Unlike the commercial systems, dimples in the blanket and reflector grids were designed to have pyramidal foundations (Figure 30) to provide additional panel stiffness necessary to react the higher spring forces in these two regions.

LWBR and Alloy 718 commercial grid spring configurations are similar in that both are "leaf" springs with foundational attachments at both ends. The Zircaloy springs of the CE System 80 reactor; however, are cantilevered.

Commercial reactors generally have no containment shell surrounding each module of fuel rods and grids. In the LWBR core, both the seed and reflector type modules have Zircaloy-4 shells for proper control of coolant flow (Reference 5). Grid-to-shell clearances as well as peripheral rod-to-shell clearances were considered in the grid design. Fuel rod bow and shell deflections under pressure gradients and differential thermal expansion effects could lead to reduced coolant channel spacing and "hot spots."

The grids in commercial systems are often positioned at their designated axial elevations by vertically positioning spacer sleeves between grids or by attaching the grids to support rods or guide tubes located within the grid array. In the LWBR core, the grids are bolted to long, slender Zircaloy-4 support posts, which in turn are bolted to support plates at the top and bottom of the modules, and to Zircaloy-4 support shells in the seed and reflector 
modules. The internal boundaries of the blanket grids are supported by attachment to the blanket guide tube to maintain cell alignment and to transmit some of the loads to the guide tube.

Two other features unique to the LWBR systern are noted. The LWBR grids contain no control rods of any kind. Reactivity control is provided by alignment of the movable seed assembly relative to the stationary blanket assembly, thereby controlling the fissile material geometry. In addition, LWBR grids do not contain fllow mixing vanes as found in some commercial systems. The smaller spacing between rods and grids and the desire to minimize grid material volume eliminated such vanes from the LWBR grid design.

\section{AC'KIVUWLELCMMEIV 'L"'}

The author wishes to express his appreciation to many nf his rnllpagups and predecessors who assisted in the technical preparation and review of this document. In particular, the author wishes to recognize the original grid design work of Mr. R. Spada, Mr. D. F. Meyex, Mr. L. O. DelGeorge, and Mr. M. J. Schncider. Mr. R. M. Clask pruvided hielprul guldance on the structural analysis methods, Mr. D. A. Gorscak supplied information on the grid structural testing, Mr. B. Z. Hyatt provided information on the stress relaxation of AM-350, and Dr. R. A. Wolfe contributed information on the spring follow analysis. The author wishes to express his appreciation to Mr. R. A. Frederickson, Dr. J. Belle, Mr. I. Goldherg, and Mr. M. D. Novotnak for their overall assistance and guidance in the preparation of this report.

\section{REFFRENCES}

1. D. R. Connors, et al, editors, "Design of the Shippingport LWBR," WAPDTM-1208, January 1979.

2. B. R. Gourley, "Decarburization of AM-350 Stainless Steel T.WRR Fuel Rod Support Grids," WAPD-TM-1131, February 1.977.

3. J. W. Barbour, "Corrosion Evaluation of Nickel-Base Brazing Filler Metals Intended for Use in Support Grid Applications," WAPD-TM-1184, September 1978.

4. L. P. Ebejer, "Brazing of AM-350 Stainless Steel LWBR Fuel Rud Support Grids," WAPD-TM-1297, February 1979. 
5. Shippingport Atomic Power Station Safety Analysis Report for the Light Water Breeder Reactor, Volume 4, Chapter 4, 1975.

6. W. H. Harden, III, "Effect of Cladding Ovality and Diametral Creep on Fuel Rod Support Systems," WAPD-TM-714, December 1970.

7. Westinghouse Nuclear Energy Systems, Reference Safety Analysis Report for the RESAR 414, Docket. No. STN 50-572, October 1976.

8. Babcock and Wilcox, Standard Safety Analysis Report, B-SAR-205, Docket No. STN 50-561, February 1976.

9. Combustion Engineering, Standard Safety Analysis Report, CE System 80, Amendent No. 3, Docket No. STN 50-470, June 1974. 
TABLE 1. GRID AXIAL SPACING

\section{Seed Module}

Span

Grid Level 9 to Top Base Plate

Level 8 to Level 9

Level 7 to Level 8

Level 6 to Level 7

Level 5 to Level 6

Level 4 to Level 5

Level 3 to Level 4

Level 2 to Level 3

Level 1 to Level 2

Bottom Base Plate to Level I
Span Length, Inches

3.75

17.80

14.50

12.30

12.10

12.00

12.70

12.90

16.70

3.75

\section{Blanket Module}

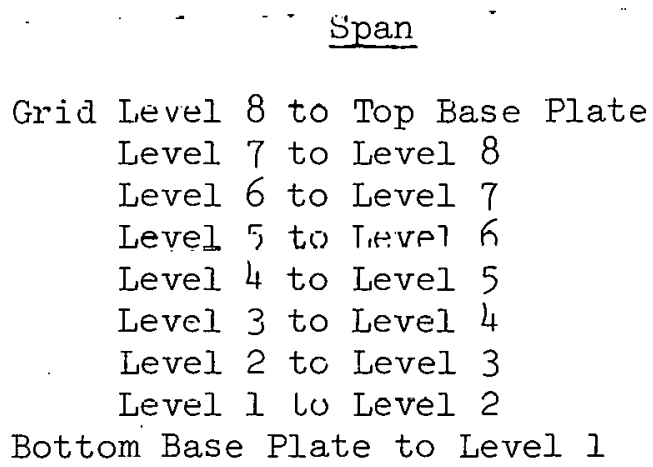

Grid Level 8 to Top Base Plate Level 7 to Level 8 Level 6 to Level 7 Level 5 to Tirvel 6 Level 4 to Level 5 Level 3 to Level 4 Level 2 to Level 3 Level 1 lo Level 2 Bottom Base Plate to Level I

Span Length, Inches

5.00

16.50

16.25

15.80

14.50

15.60

16.00

16.50

4.50

Ficilector Module

\section{Span}

Grid Level 6 to Top Base Plate Level 5 to Level 6 Level 4 to Level 5 Level 3 to Level 4 Level 2 to Level 3 Level 1 to Level 2 Bottom Base plate to Level I
Span Tiength, Inclues

7.00

21.50

20.00

15.85

20.00

21.50

7.00 
TABLE 2. COMPOSITIONAL LIMITS OF AM-350*

\section{Element}

Carbon

Chromium

Manganese

Molybdenum

Nickel

Nitrogen

Phosphorous

Silicon

Sulfur

Iron
Weight Percent

$$
0.08-0.12
$$

$16.00-17.00$

$0.50-1.25$

$2.50-3.25$

$4.00-5.00$

$0.07-0.13$

$0.040 \max$

$0.50 \max$

$0.030 \max$

Balance

Reference: "Corrosion and Moderate Heat Resistant Steel Sheet and Strip, $16.5 \mathrm{Cr}-4.5 \mathrm{Ni}-2.9 \mathrm{Mo}-0.10 \mathrm{~N}$ High Temperature Annealed," AMS 5548E, No vember 1, 1968.

*The carbon and nitrogen content are subsequently reduced by the grid heat treatment processes. The final limits for carbon and nitrogen are $0.02-0.06 \mathrm{w} / 0$ and $0.01-0.08 \mathrm{w} / \mathrm{o}$ (provided the average carbon and nitrogen is equal to or greater than $0.04 \mathrm{w} / \mathrm{o}$ ). 
TABLE 3. MECHANICAL PROPERTIES AND STRESS LIMITS OF AM-350 SHEET, BAR, WIRE, AND Ni-30 Cr-IOSi BRAZEMENT USED IN AM -350 GRIDS

AM-350 Material

Property/Limit

Tensile Strength (min.)

Yield Strength $(\min$.

Elastic Modulus

Poisson's Ratio (elastic)

Mean Coefficient of Thermal

Expansion (68 to $592 \mathrm{~F}$ )

Primary Membrane Stress

Intensity Limit ( $\mathrm{Sm}=1 / 3 \mathrm{Su})$

Primary Membrane plus

Bending stress Intensity

Limit $(1.5 \mathrm{sm})$

Primary Shear Stress

Limit. $(0.6 \mathrm{sm})$

Primary and Secondary Stress

Intensity Limit ( $3 \mathrm{Sm}$ )

Peak Stress intensity Limit
Koom Temperature

135,000 psi

125,000 psi (100,000 psi Bar)

$29.4 \times 10^{6} \mathrm{psi}$

0.281

$6.3 \times 10^{-6}$ in/in $F$

45,000 psi

$67,500 \mathrm{psi}$

27,000 psi

$135,000 \mathrm{psi}$

Calculated peak stresses used in fatigue analysis in conjunction with fatigue design curve I-9-I of Section III ASME Boiler drul Pressure vessèl lóde

\section{NI-30cr-10S 1 Brazement s}

Primary Membrane Stress Intensity $(\mathrm{Sm}=1 / 3 \mathrm{Su})$

Primary Shear Stress Intensity $(0.6 \mathrm{Sm})$

Primary Membrane plus Primary

Bending Stress Intensity ( $1.5 \mathrm{sm}$ )

Primary and Secondary Stress Intensity ( $3 \mathrm{Sm}$ )

Peak Stress Intensity

$$
\begin{array}{r}
\text { 8,000 psi } \\
\text { 4,800 psi } \\
12,000 \text { psi } \\
24,000 \text { psi }
\end{array}
$$

Allowable values based on fatigue curve, Figure B-2, Appendix B

*Values given are for $600 \mathrm{~F}$

References: 1. Shippingport Atomic Power station Safety Analysis Report for the I,ight. Water Breeder Reactor, Volume 4, Table 1.2.2...3, 1975

2. ASME Boiler and Pressure Vessel Code, Section III, Division l, ASME, 1974 . 
TABLE 4. AS-MANUFACTURED GRID CELL SPRING FORCE REQUIREMENTS

\begin{tabular}{|c|c|c|c|c|c|}
\hline \multirow[b]{2}{*}{ Grid } & \multirow[b]{2}{*}{ Cell } & \multicolumn{2}{|c|}{$\begin{array}{l}\text { As-Manufactured Spring } \\
\text { Force Requirement, Ib. } \\
\text { (Room Temperature) }\end{array}$} & \multicolumn{2}{|c|}{$\begin{array}{c}\text { Equivalent Spring } \\
\text { Force, lb at } \\
\text { Operating Temperat ure* }\end{array}$} \\
\hline & & Minimum & Maximum & Minimum & Maximum \\
\hline Seed & All & 3.0 & 5.1. & 2.7 & 4.5 \\
\hline $\mathrm{Bl}$ anket & St andard & 6.7 & 13.8 & 5.9 & 12.1 \\
\hline & $\begin{array}{l}\text { Power- } \\
\text { Flattening }\end{array}$ & 6.7 & 13.8 & 5.9 & 12.1 \\
\hline Reflector & Basic & 6.9 & 18.3 & 6.1 & 16.1 \\
\hline & $\begin{array}{l}\text { Narrow } \\
\text { (Boundary) }\end{array}$ & 6.9 & 18.3 & 6.1 & 16.1 \\
\hline & Wi de & 14.0 & 23.2 & 12.3 & 20.4 \\
\hline
\end{tabular}

*Equivalent hot spring force conversion factor $=0.88$, based on ratio of hotto-cold elastic modulus for AM-350. 
TABLE 5. MINIMUM SPRING DEFLECTION REQUIREMENTS AT BEGINNING-OF-LIFE

\begin{tabular}{cc} 
& $\begin{array}{c}\text { Minimum Required } \\
\text { Spring Deflection } \\
\text { With Minimum }\end{array}$ \\
Type & Diameter Rod \\
Spring & (inch) \\
\hline
\end{tabular}

0.015

Seed

Blanket -

St andard

Power-Flattening

Reflector -

Basic

Narrow

Wide
0.021

0.028

0.017

0.023

0.023
Free Spring Position* . Corresponding

To Minimum

Spring Deflection

0.136 (inch)

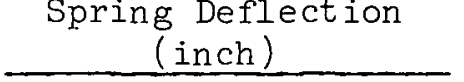

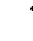

* Free Spring Position is the distance from the cell centerline to the spring in its free (undeflected) position. 
TABLE 6.. GRID DESIGIN CORIPARISOIJ

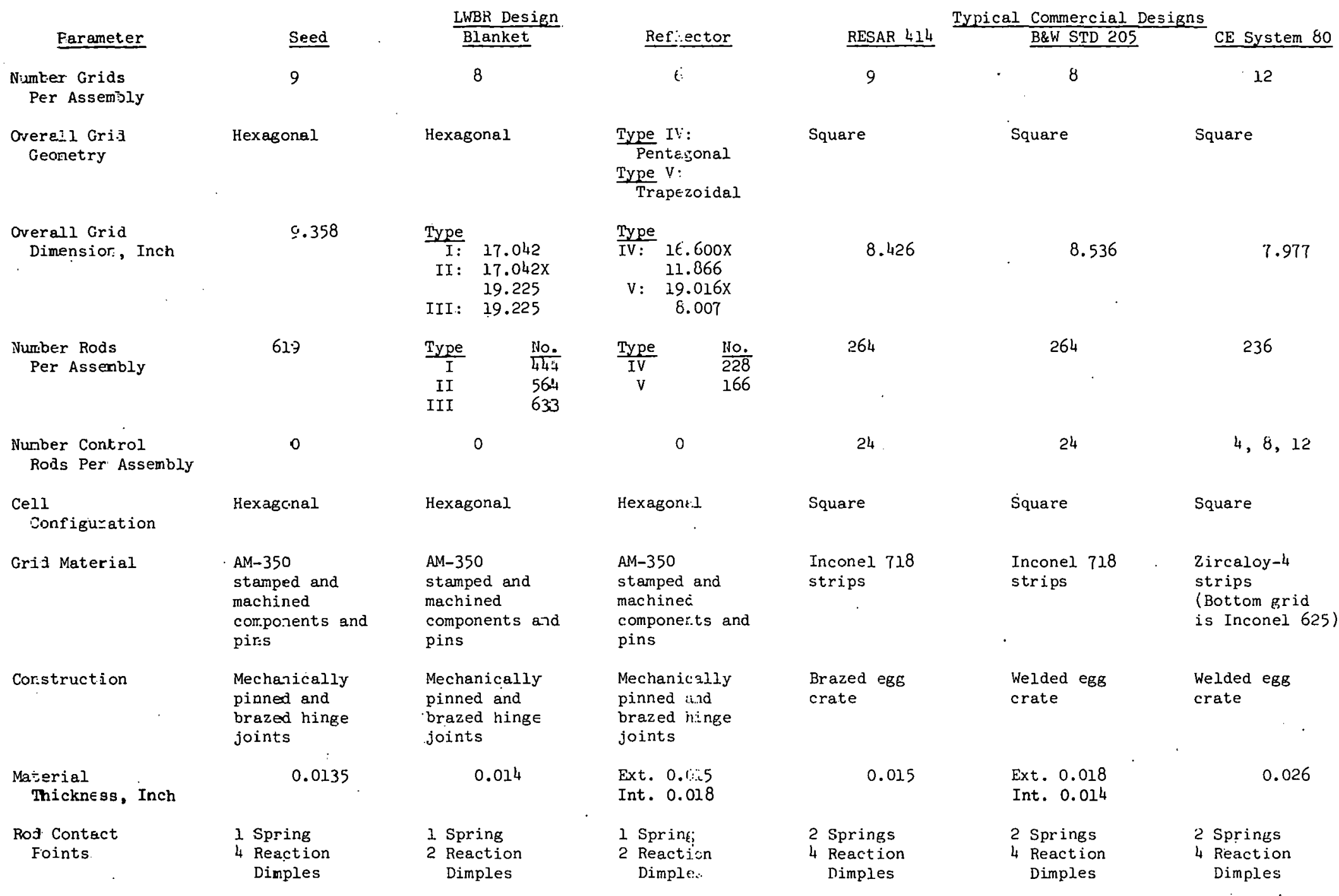


Parameter

Type Spring

Type Dimple

Dimple Location
Relative to
Panel
Orientation of
Spring and Dimpie
Panels in CEIl
Method of
Axial support

Flow mixing vares

\section{Assembly \\ Containment}

Rod pitch, inch

Rol outside

Diemeter, inct.

Pitch to rod

Jiameter rati:

Rod cladding

Thickness, inoh $\underline{\text { Seed }}$

Leaf with both ends fixed,

central

cylindrizal

dimple a

panel mi hheight

Cylindrival

contact surface

$\supseteq$ near top

2 near bottom

$120^{\circ}$ apart

bolted to Zirc-4

structural

support posts

which are bolted

to Zirc-4 shell

(can)

NO

Zircaloy-4 can

0.369

0.305

1.21

0.022
LWBR Design

Blanket

Jeaf wi-h both ends fixed.

central

cylindr

dimple at

panel midheight

Cylindrica?

contact su-face

en pyramidal

kase

$z$ at.mitheight

$120^{\circ}$ apart

Grid cornectors

boltec to Zirc-

structural

support pos's

Ir.ternal:

Grid tabs bolted

tc Zirc-4 guide

tube

canless

$$
0.630
$$

STD: 0.572

PFB: 0.527

STI): 1.10

PFE: 1.19

$\begin{array}{ll}\text { STI: } & 0.028 \\ \text { PFE: } & 0.026\end{array}$

\section{Reflector}

Leaf with both erds fixec, central

cylindrica

dimple at

panel midheight

Sylinarical

contact surface

on pyramija?

base

2 at midheig,ht

$120^{\circ}$ apar:

rid conneciors

bolted to zi:rc-

structural

support pesis

winch are

bolted to $\mathrm{Zirc-4}$

shell (can)

No

Eircaloy-4 can

0.90 :

0.83 :

1.08

$0.04 ?$

0.04

\section{RESAR 414}

Leaf with both ends fixed

Flat contact

surface

2 near top

2 near bottion

Springs $90^{\circ}$ apart

aimple pane:

opposite springs

Grid mechanically

attacied to

aircaloy cortrol

rod guide thimble

in

instrument ation

uise

Frings $90^{\circ}$

apart, dimple

panel opposite

springs

dimple at

Flat contact

surface

near top

2 near top

2 at top

2 at bottom

Springs $90^{\circ}$ apart apart, dimple panel opposite springs

Grid welded

to structural

support rods

in each grid

YES

anless

canless

0.506

0.382

1.33

0.025 
TAELE 6 (Cont)

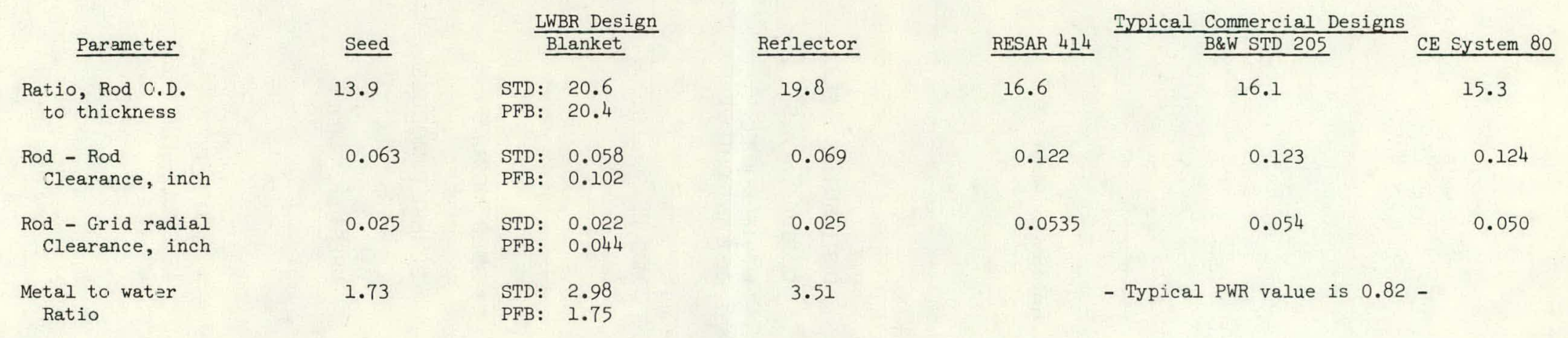




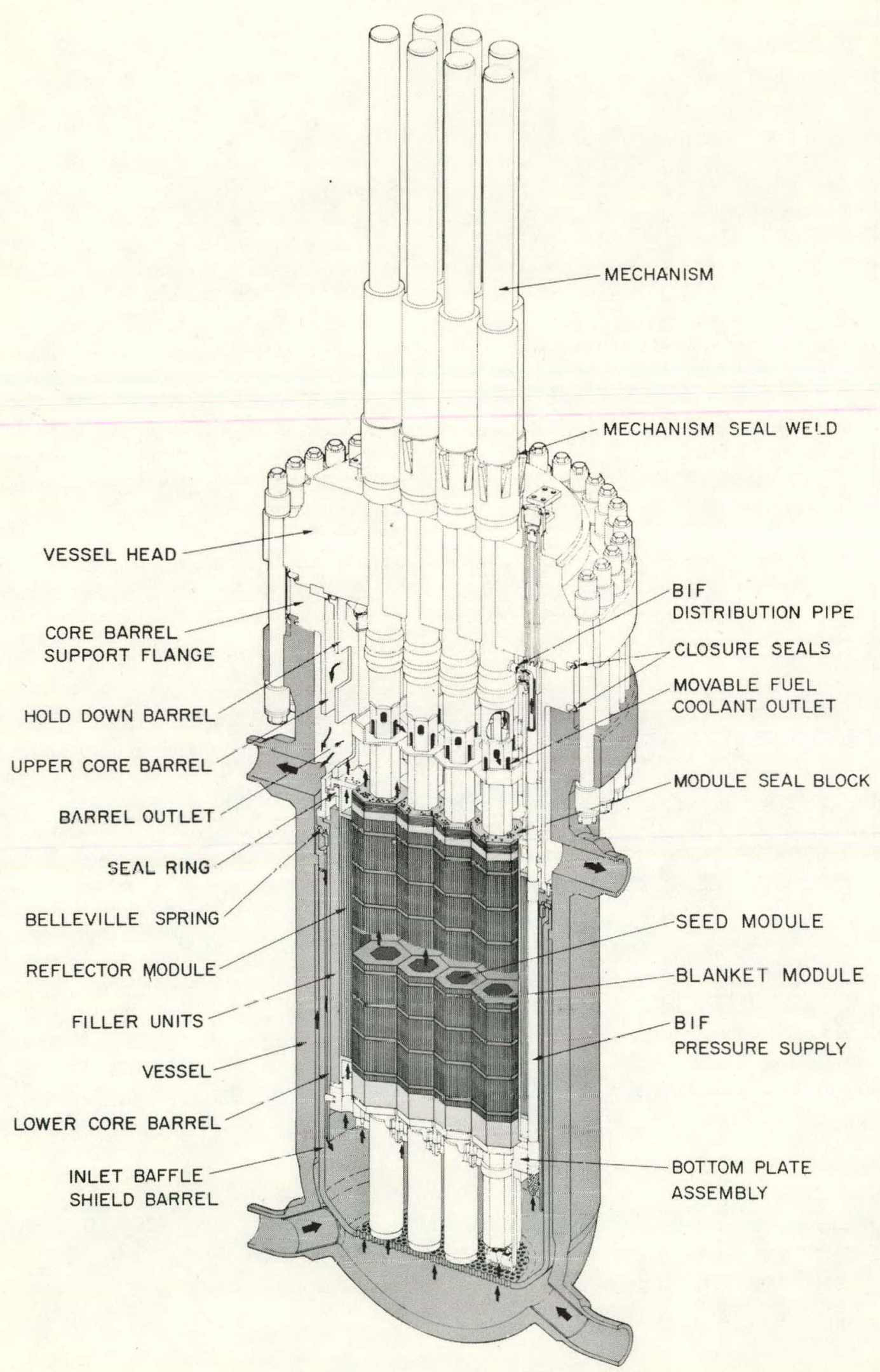

Figure 1. LWBR Reactor 


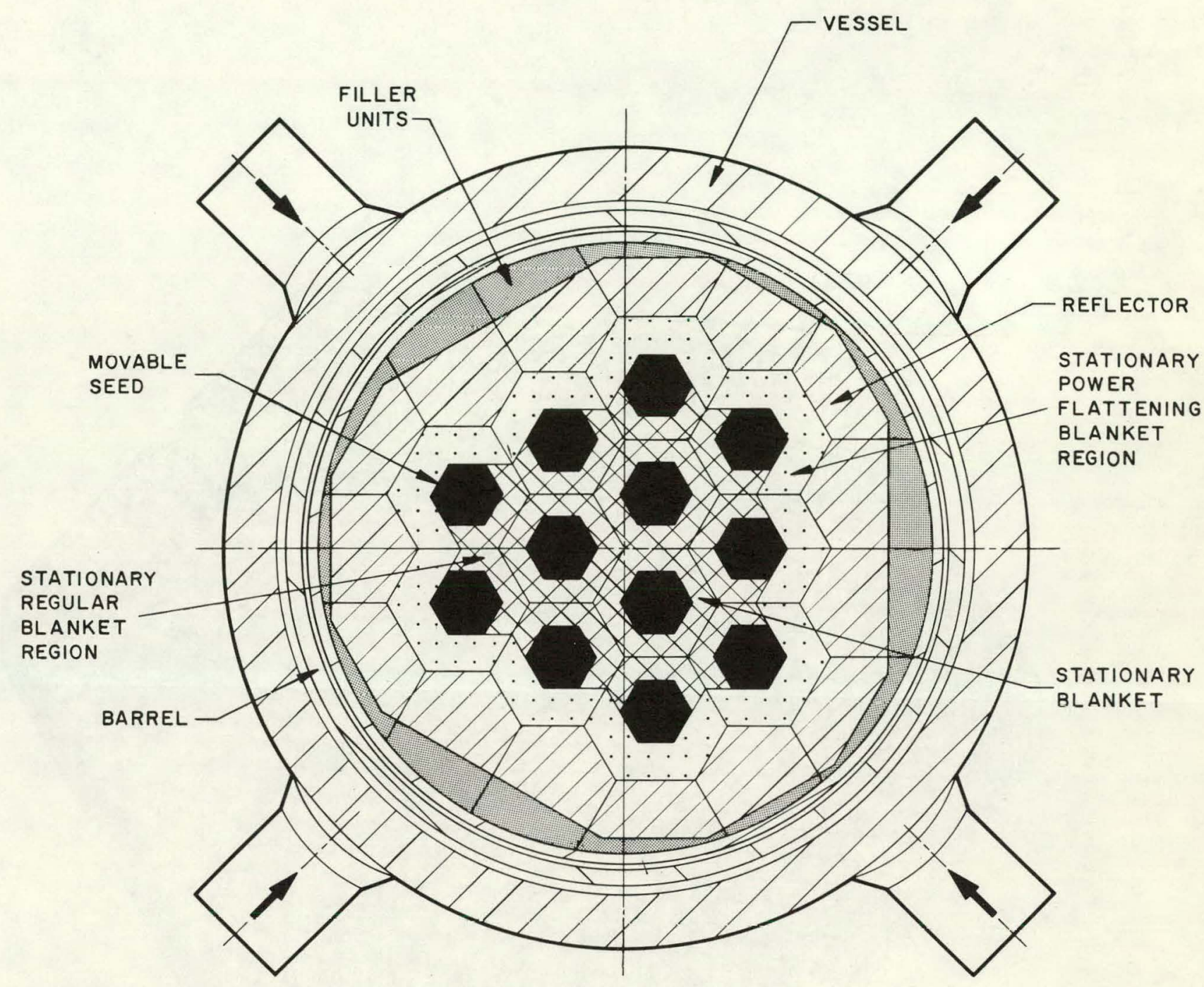

Figure 2. LWBR Core Cross Section 


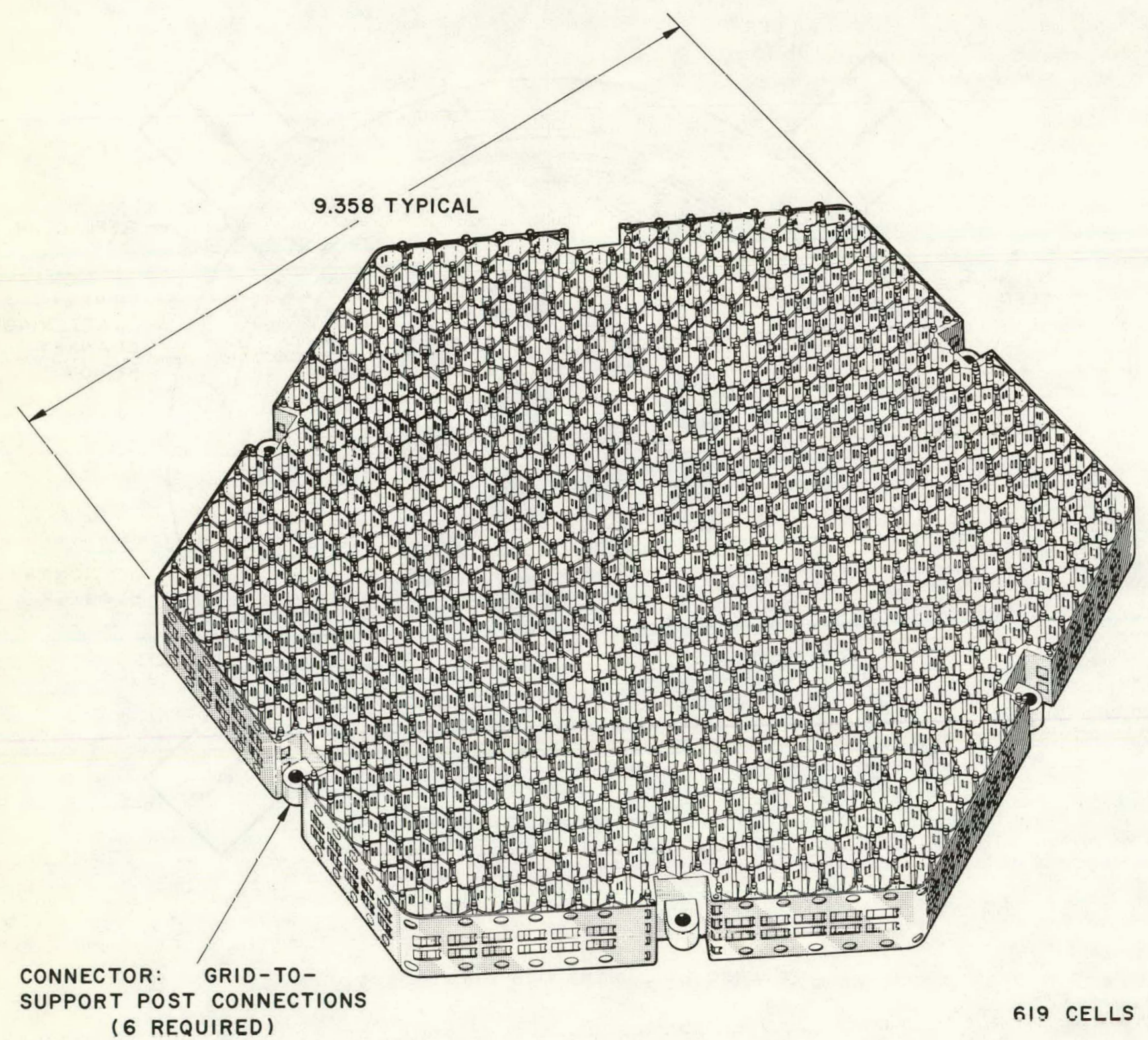

(6 REQUIRED)

Figure 3. LWBR Seed Rod Support Grid 


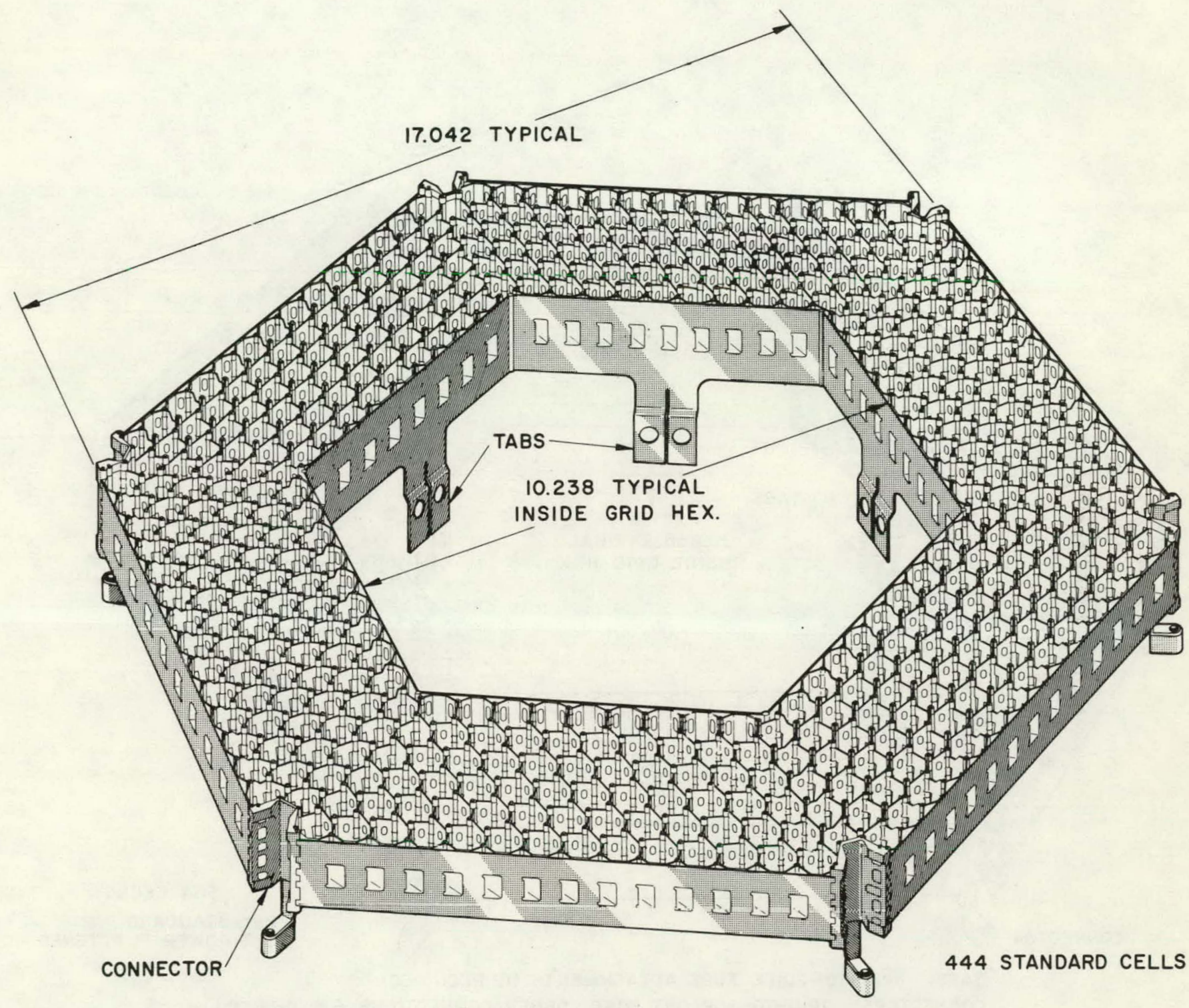

TABS: GRID-TO-GUIDE TUBE ATTACHMENTS (I2 REQUIRED) CONNECTORS: GRID-TO-SUPPORT POST CONNECTIONS ( 6 REQUIRED)

Figure 4. LWBR Blanket Type I Rod Support Grid 


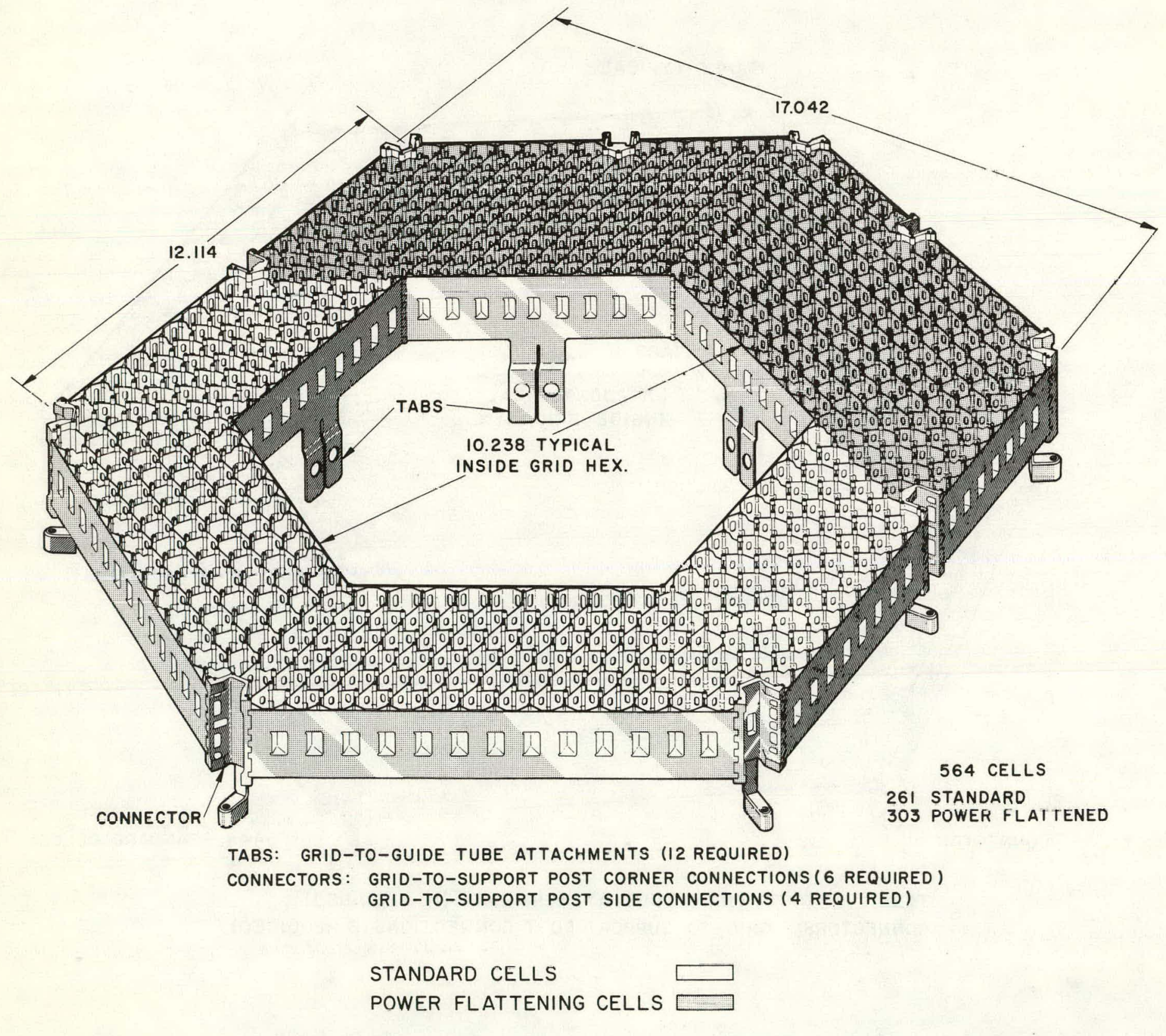

Figure 5. LWBR Blanket Type II Rod Support Grid 


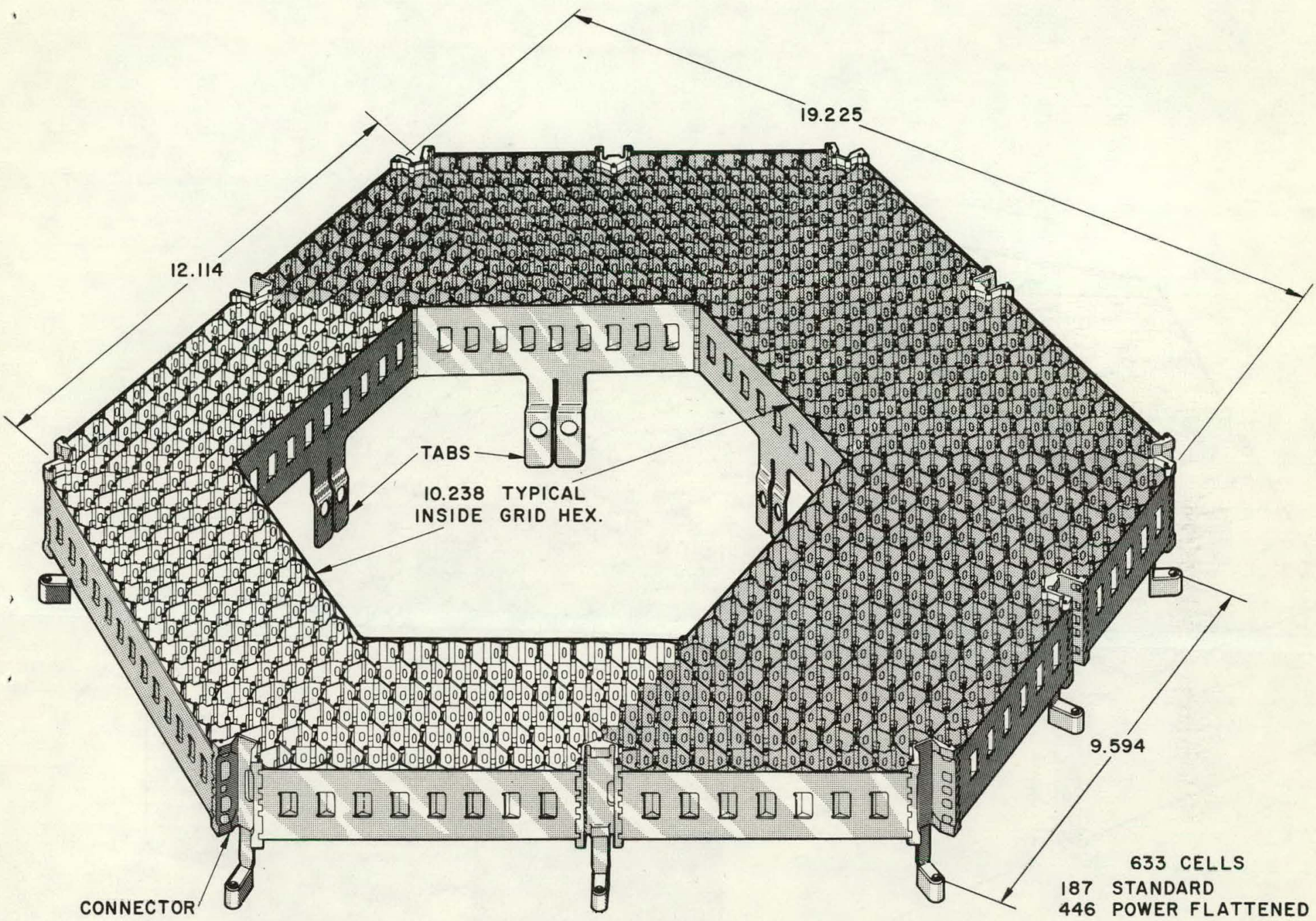

TABS: GRID-TO-GUIDE TUBE ATTACHMENTS (I2 REQUIRED)

CONNECTORS: GRID-TO-SUPPORT POST CORNER CONNECTIONS ( 6 REQUIRED) GRID-TO-SUPPORT POST SIDE CONNECTIONS (5 REQUIRED)

STANDARD CELLS

POWER FLATTENING CEILS

Figure 6. LWBR Blanket Type III Rod Support Grid 


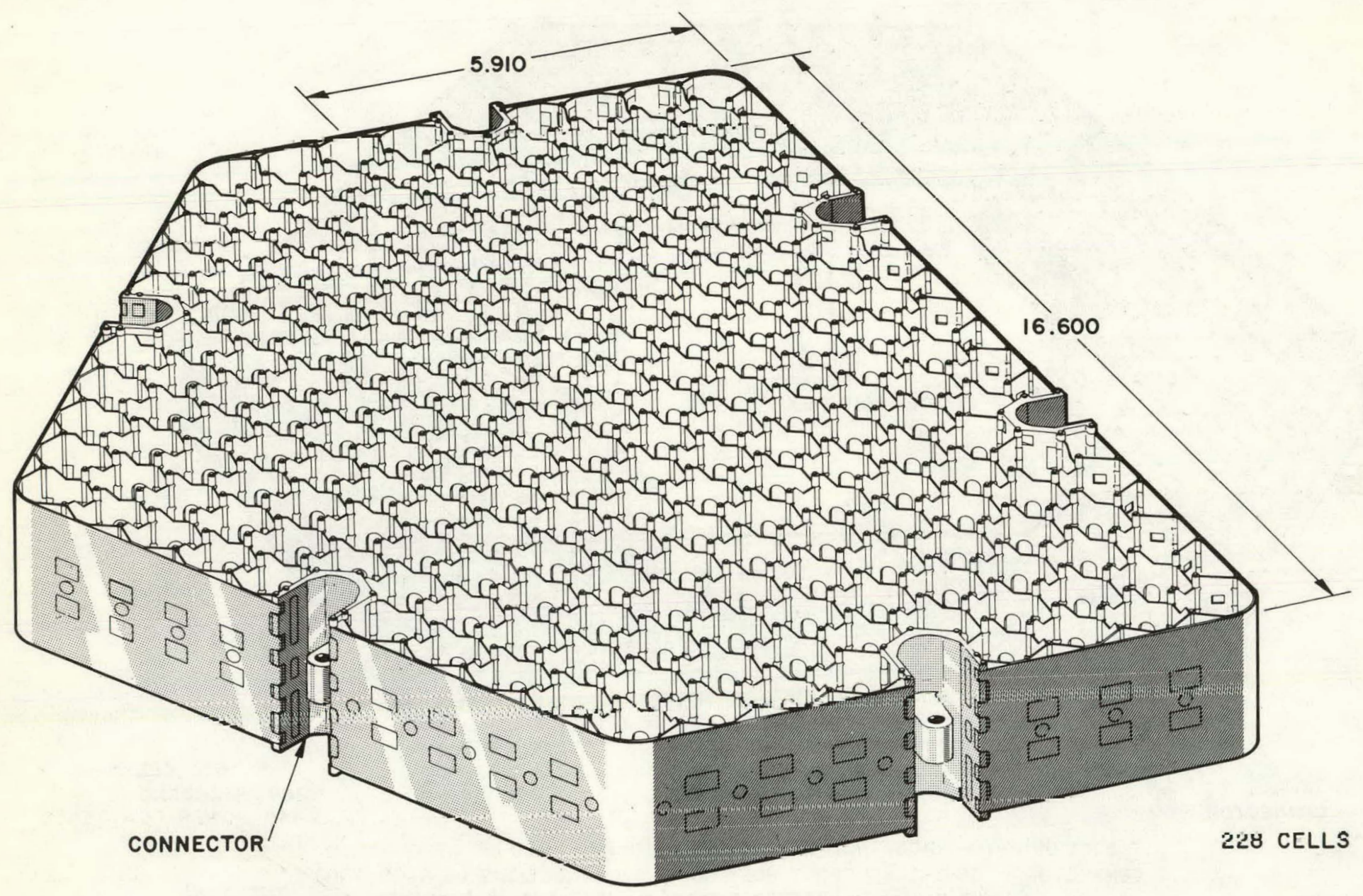

CONNECTORS: GRID-TO-SUPPORT POST CONNECTIONS ( 6 REQUIRED)

Figure 7. LWBR Reflector Type IV Rod Support Grid 


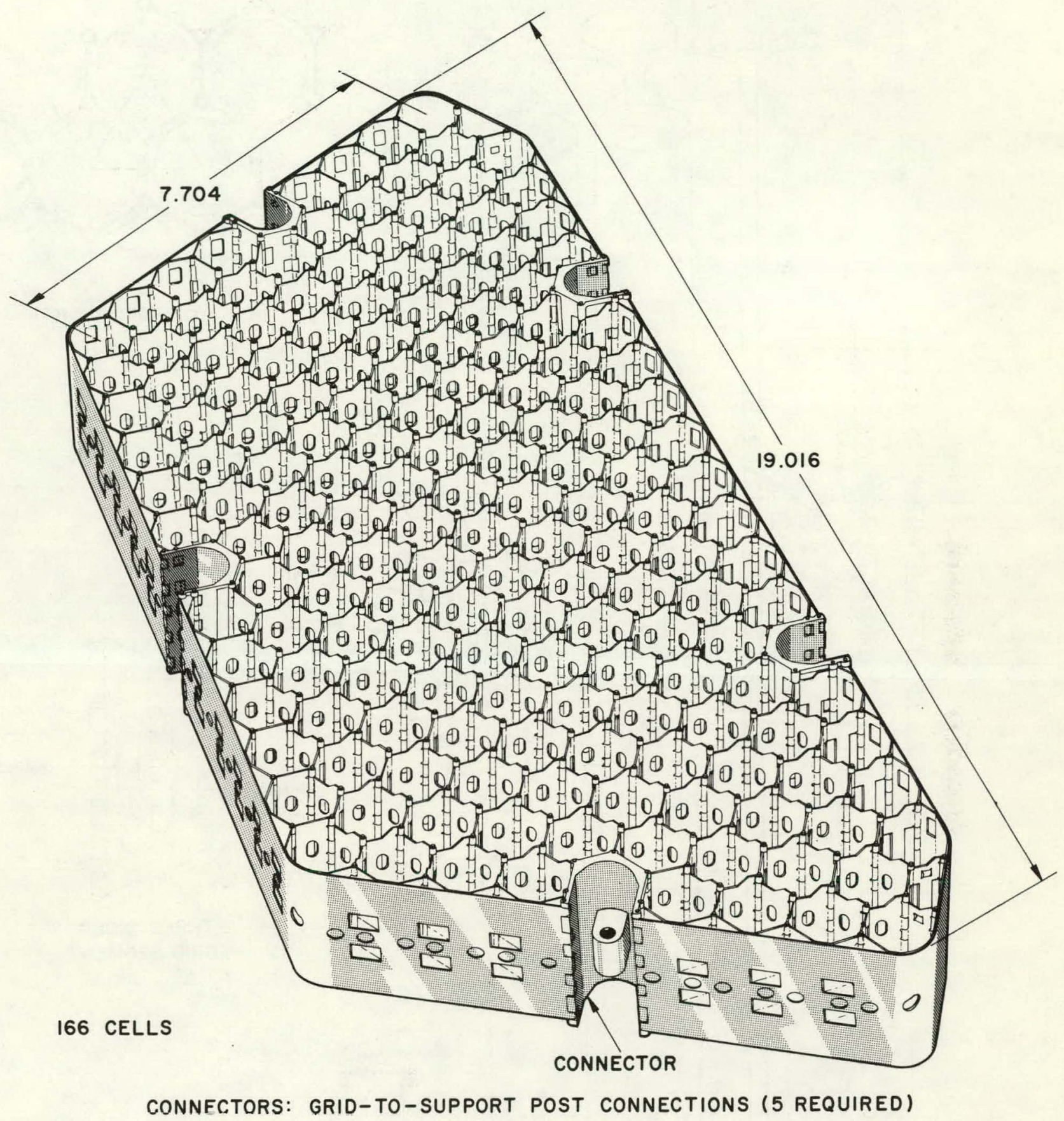

Figure 8. LWBR Reflector Type V Rod Support Grid 


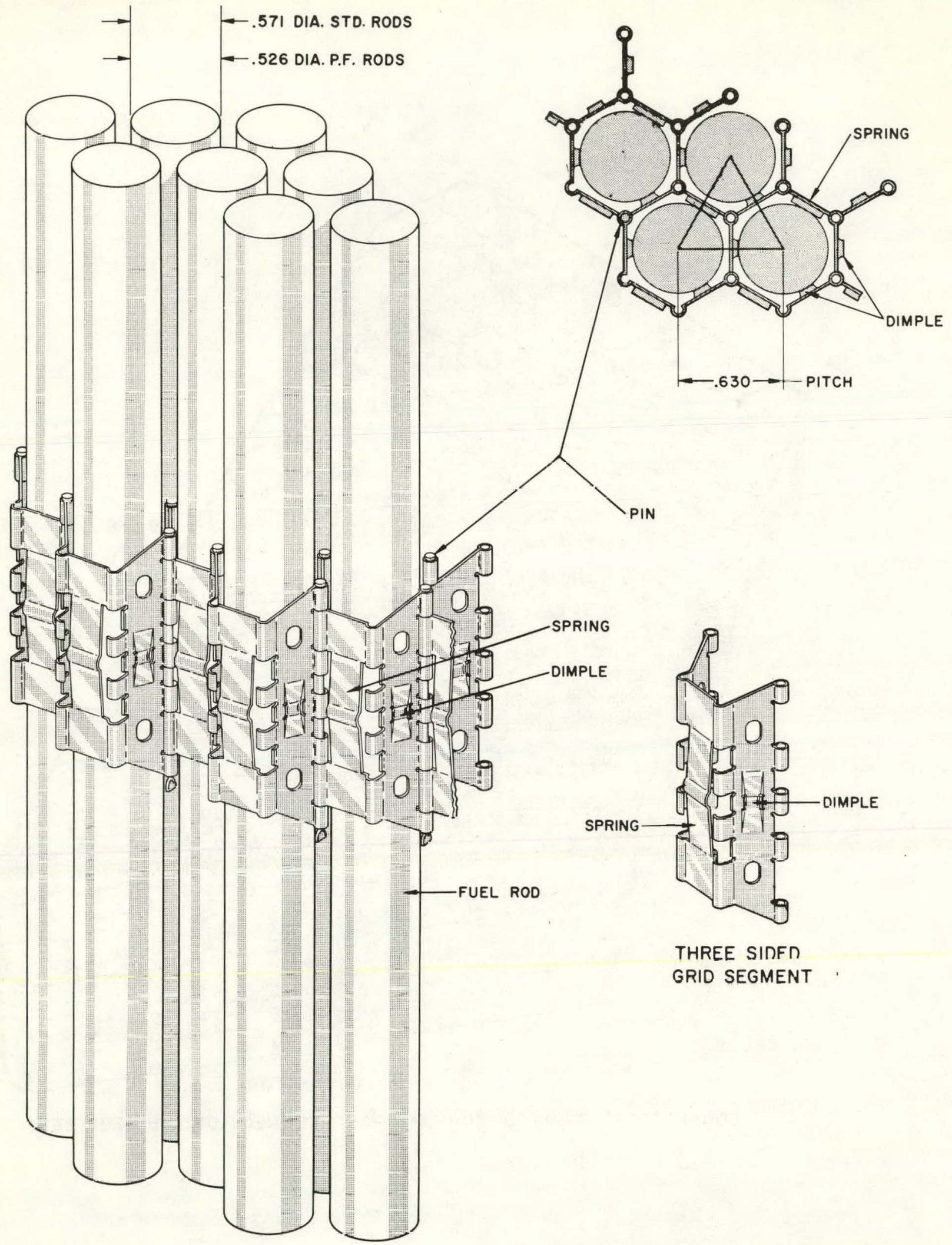

Figure 9. Typical LWBR Blanket Rod Support Grid 


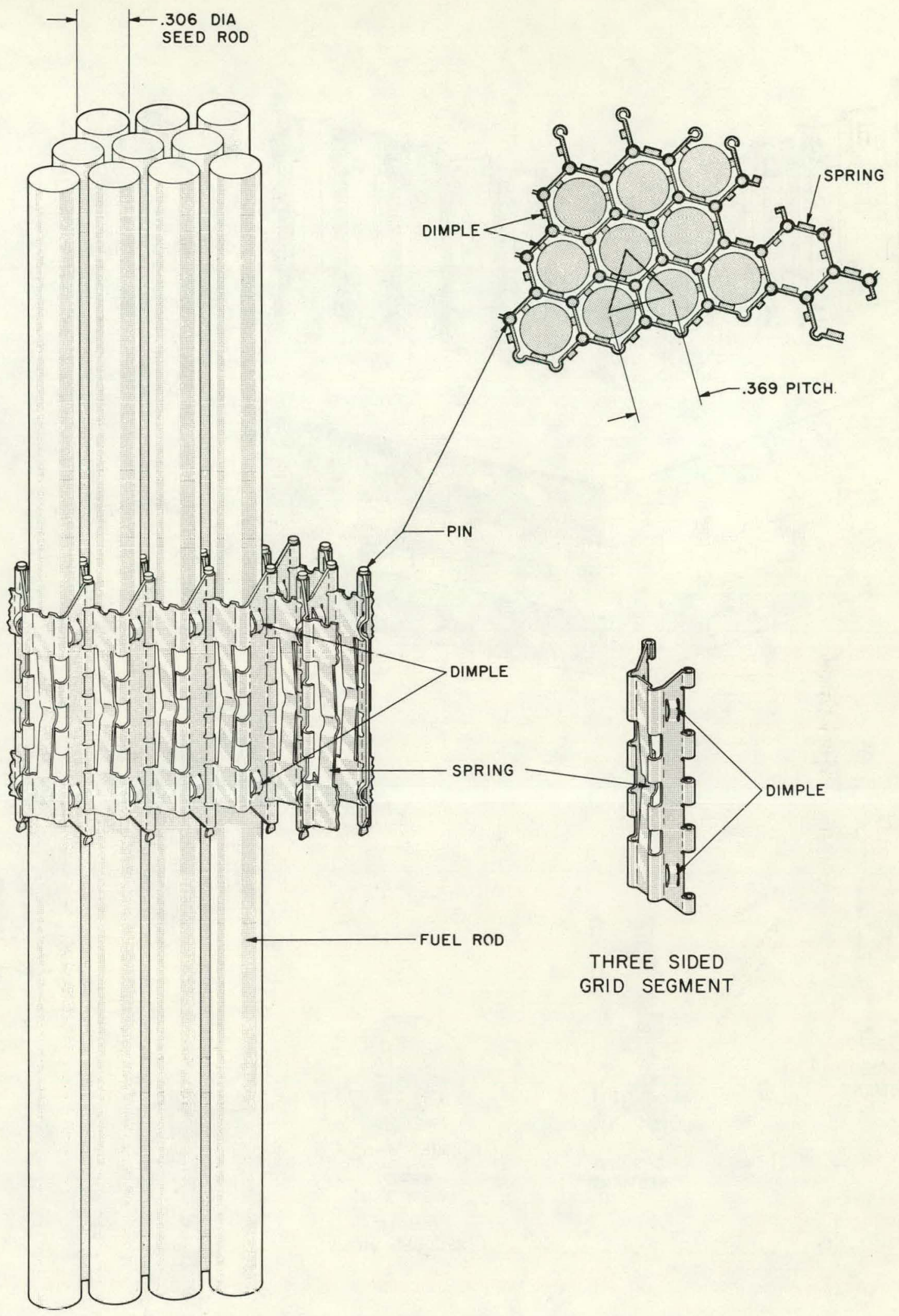

Figure 10. Typical LWBR Seed Rod Support Grid 

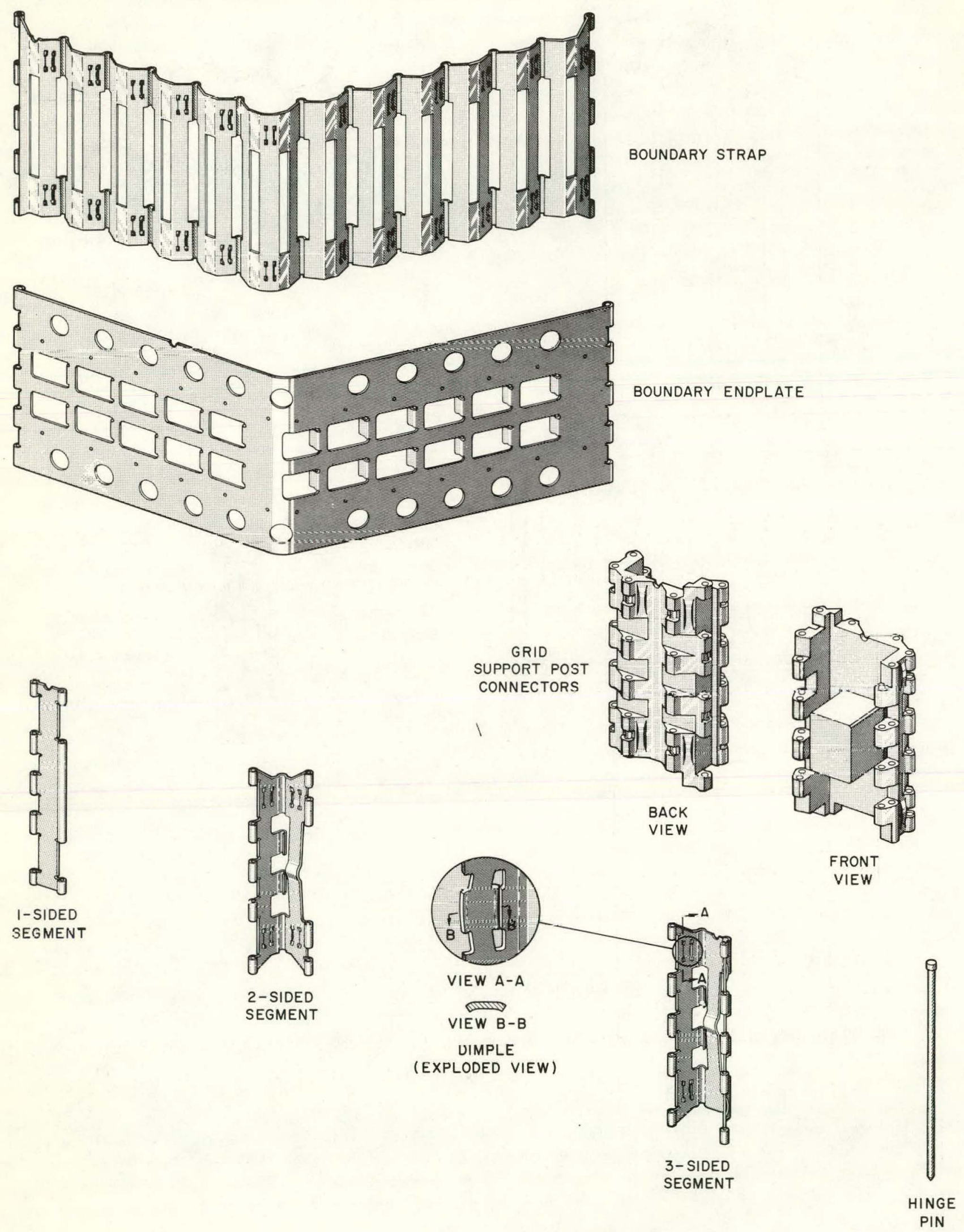

Figure 1l. LWBR Seed Grid Components 

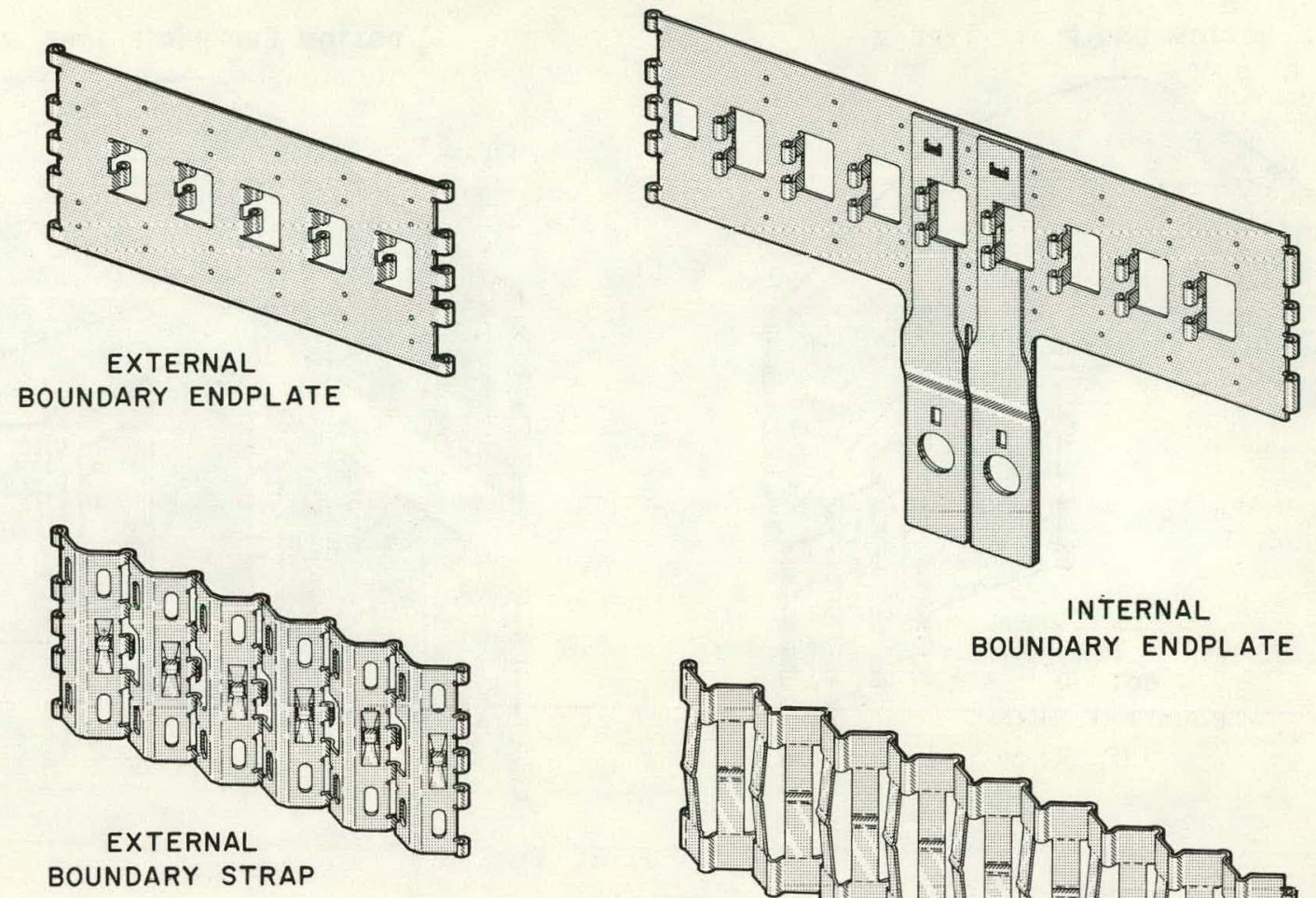

INTERNAL BOUNDARY ENDPLATE
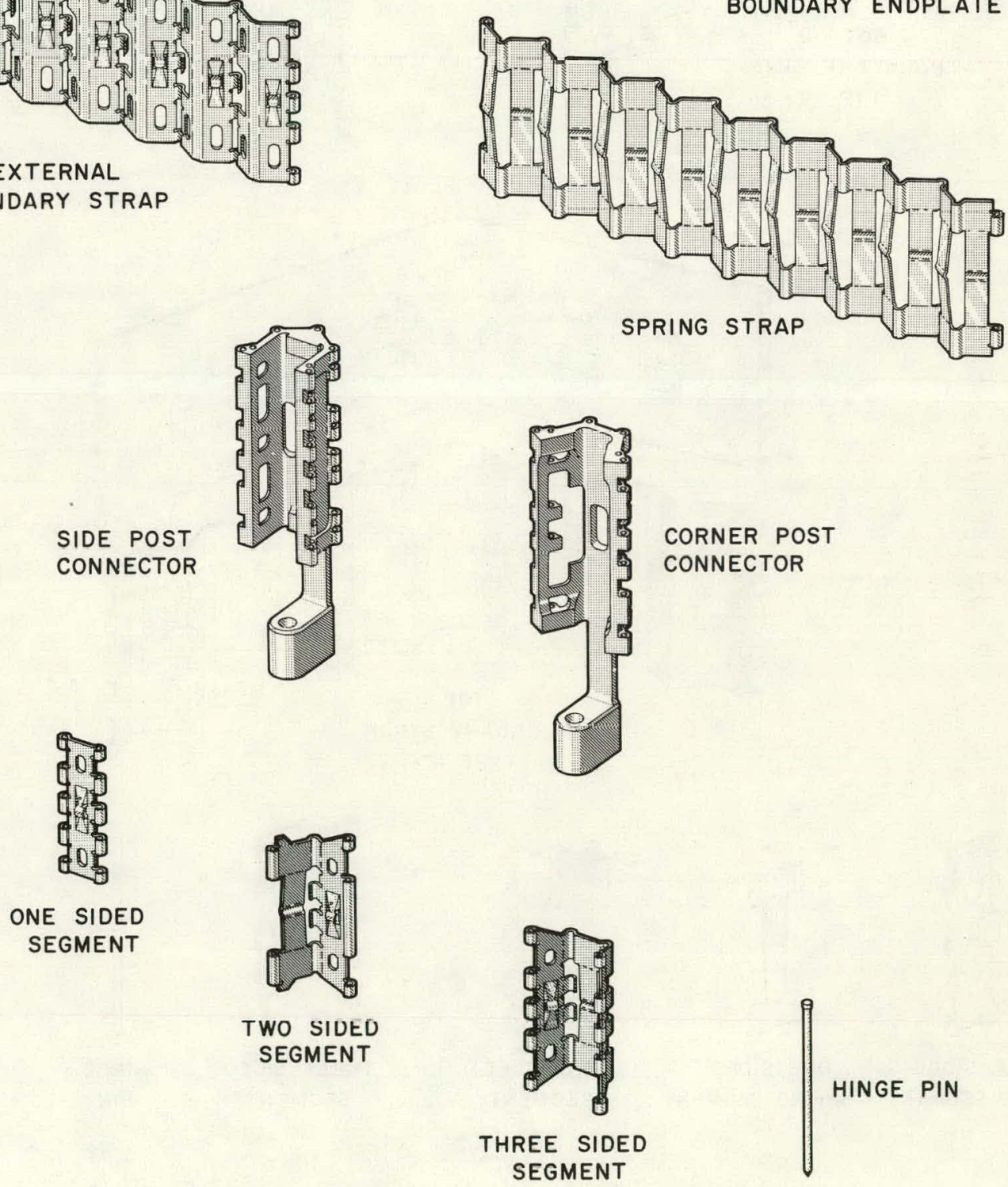

HINGE PIN

Figure 12. LWBR Blanket Grid Components 

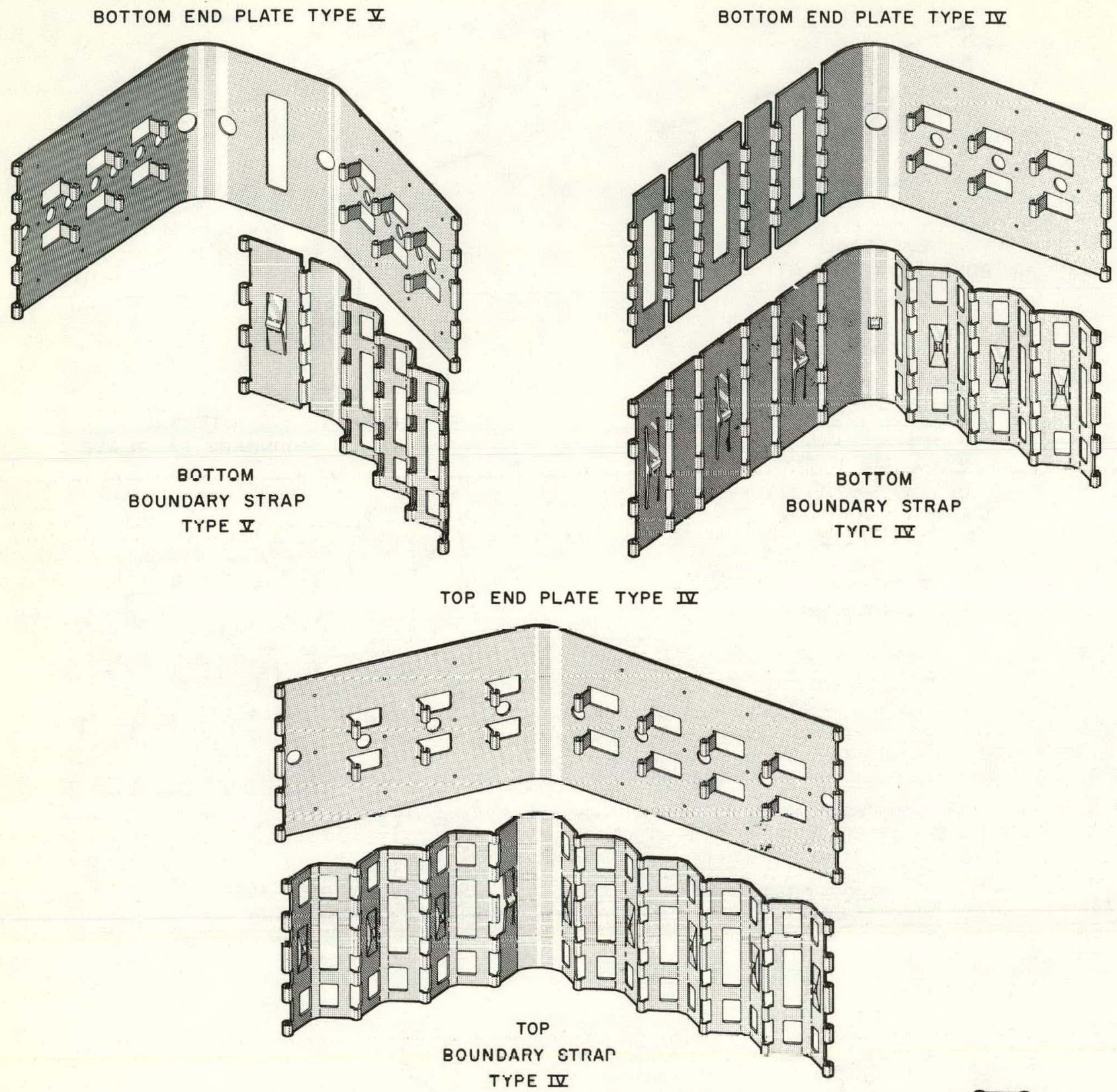

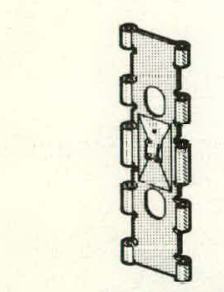

ONE SIDED

IIMPLE SEGMENT

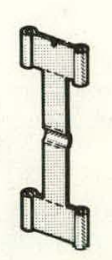

ONE SIDED

SPRING SEGMENT

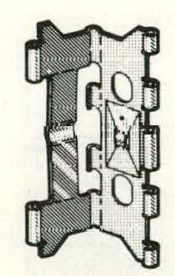

TWO SIDED SEGMENT

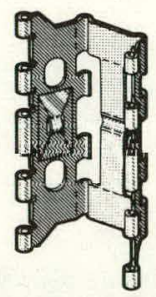

THREE SIDED SEGMENT

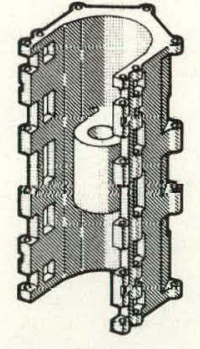

POST CONNECTOR

Figure 13. LWBR Reflector Grid Components, Type IV and Type V 

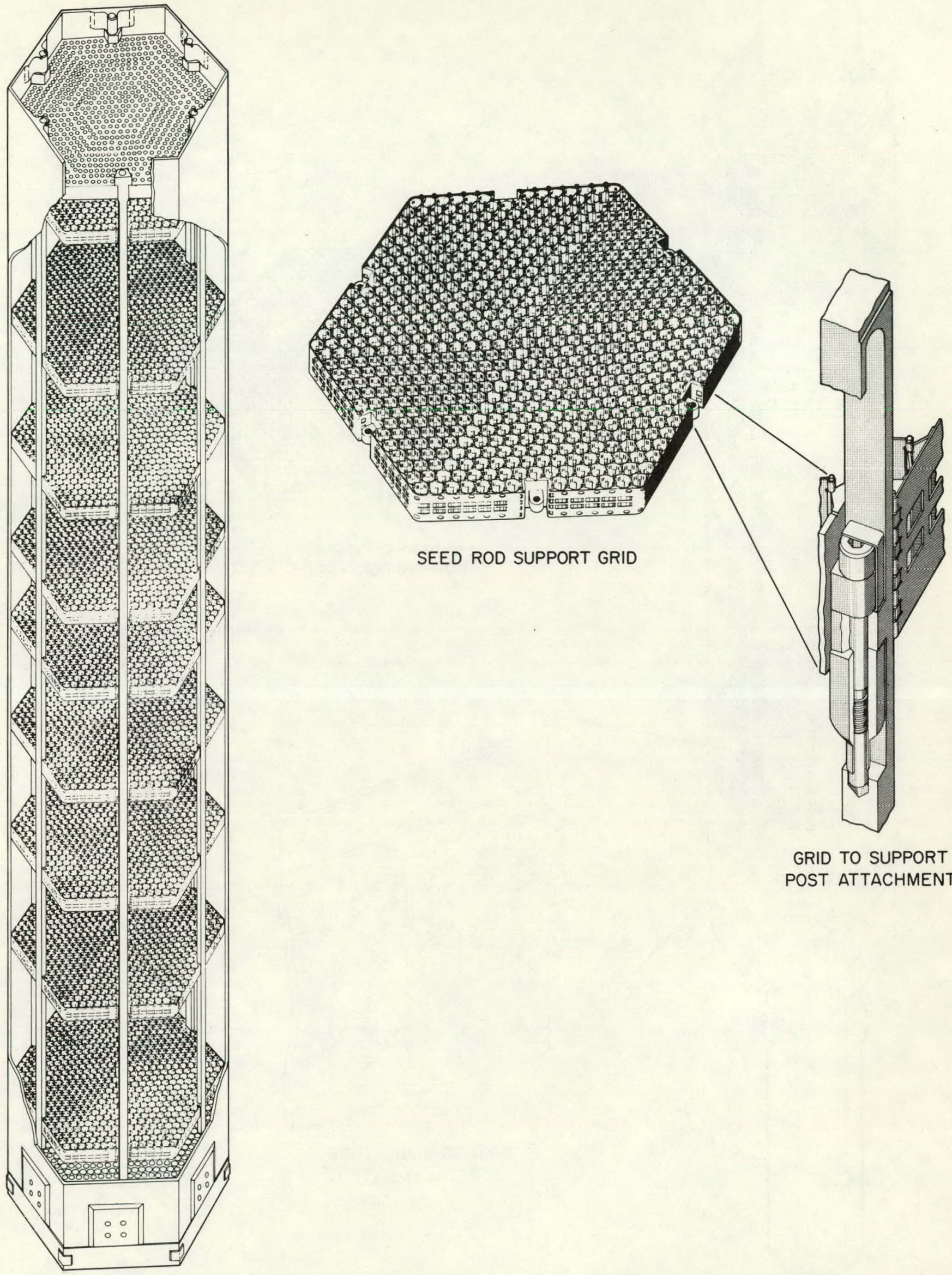

GRID TO SUPPORT

POST ATTACHMENT

Figure 14. LWBR Seed Module Assembly 


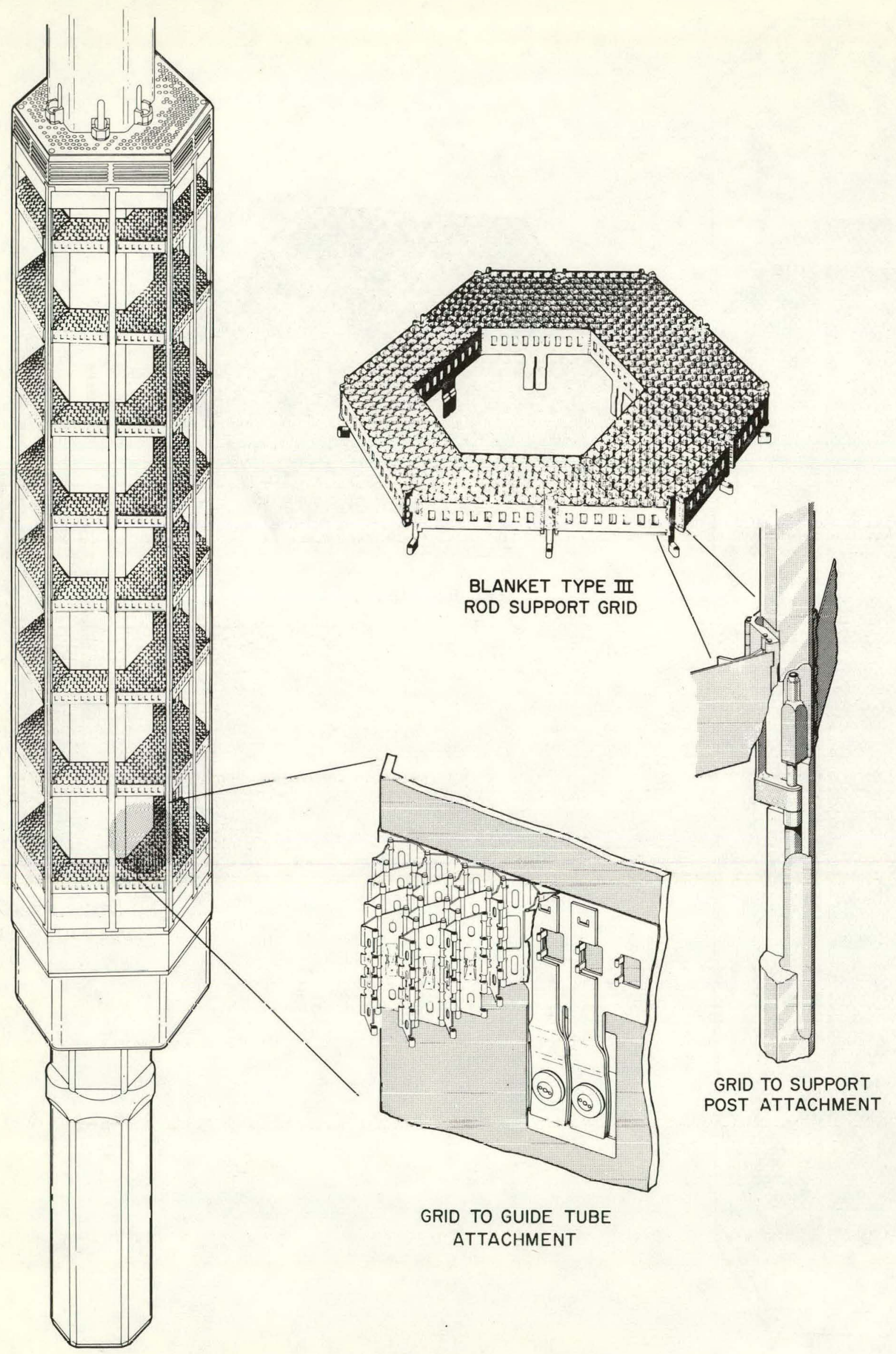

Figure 15. LWBR Blanket Type III Module Assembly 


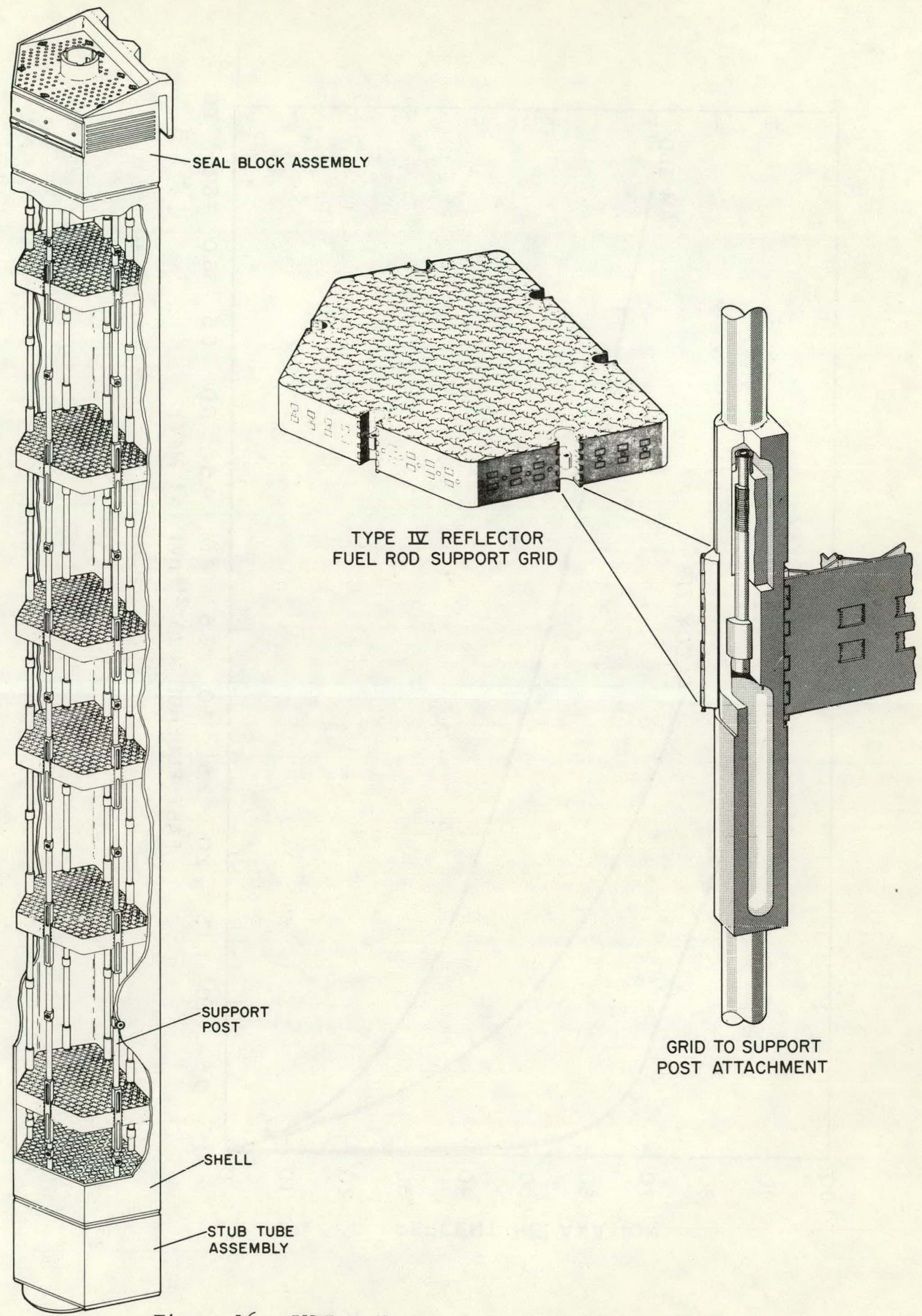

Figure 16. LWBR Reflector type IV Module Assembly 


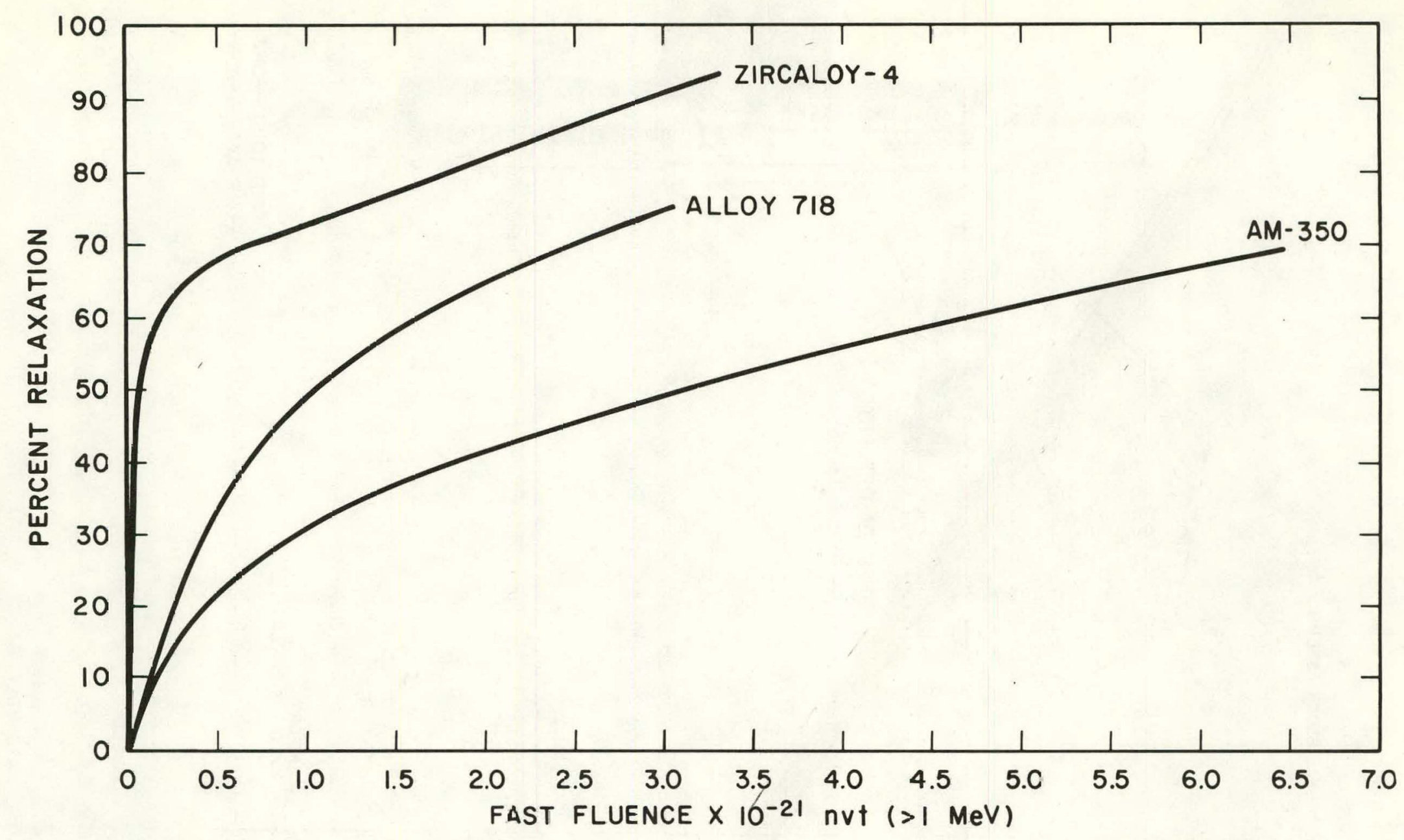

Figure 17. Percent Relaxation Versus Fast Fluence for Three Pctential Grid Materials 


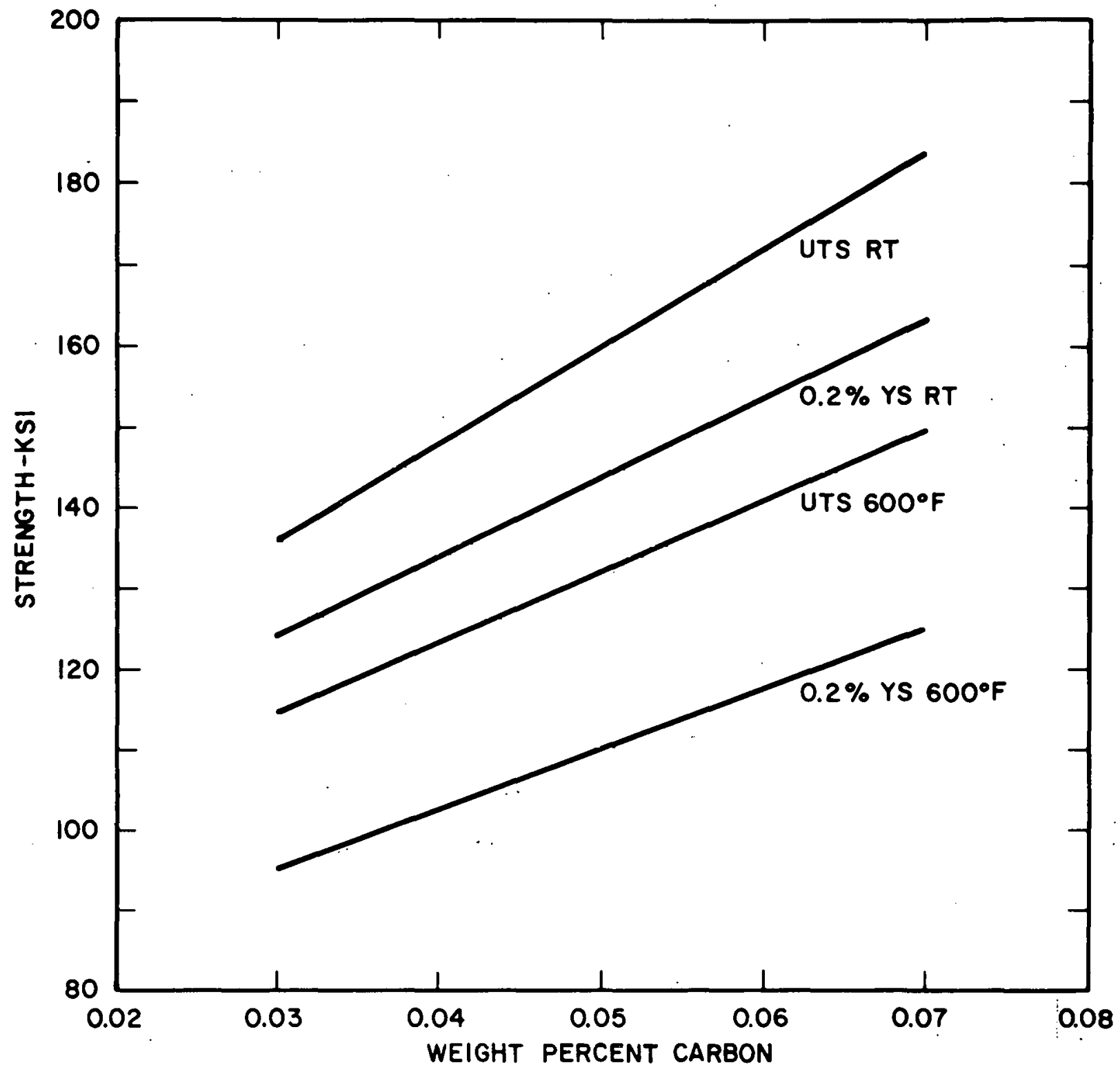

Figure 18. Room Temperature and 600F Tensile Properties of AM-350 Sheet as a Function of Weight Percent Carbon 


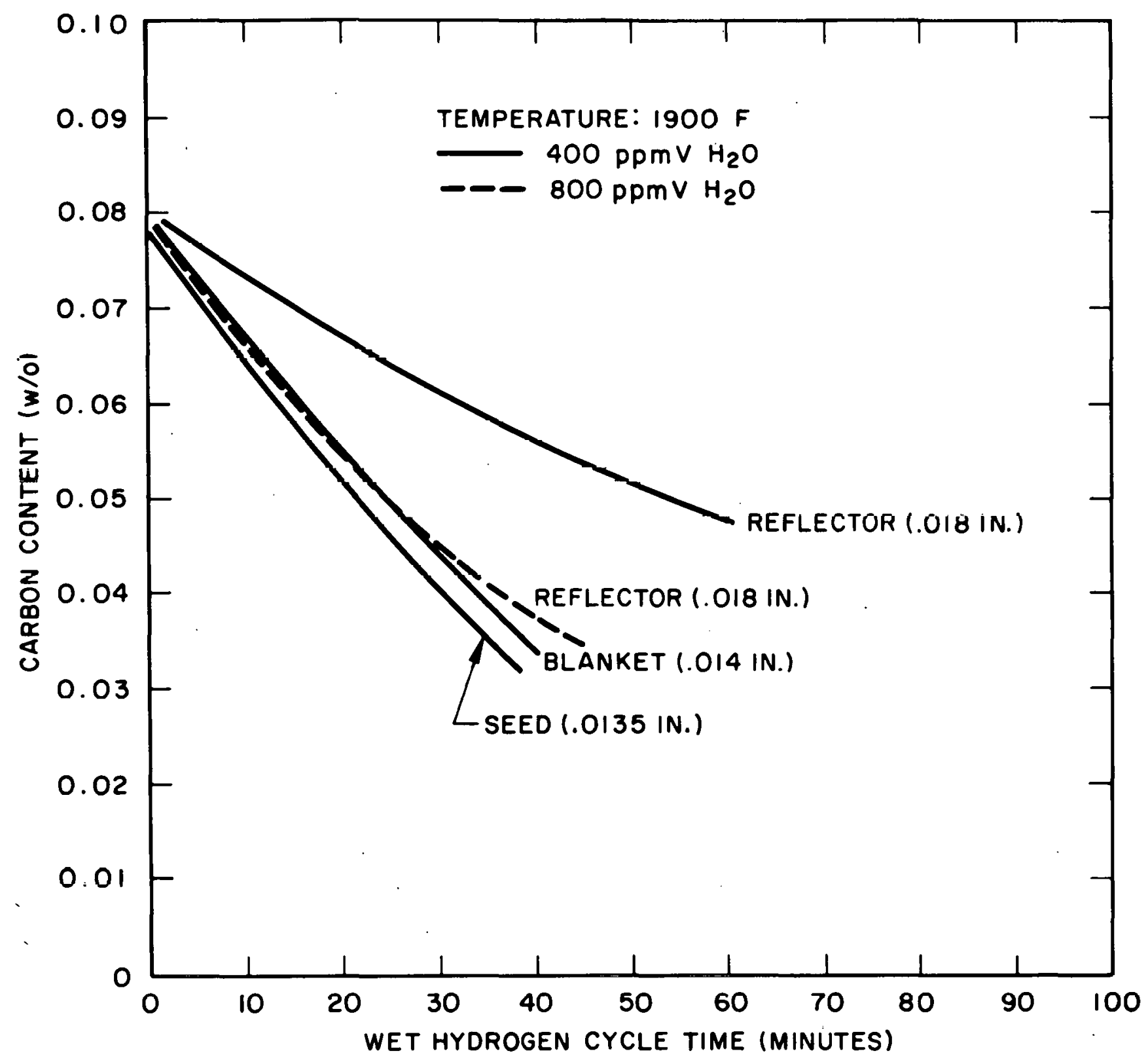

Figure 19. AM-350 Grid Carbon Content as a Function of Sheet Thickness and Wet-Hydrogen Decarburization Cycle Time 


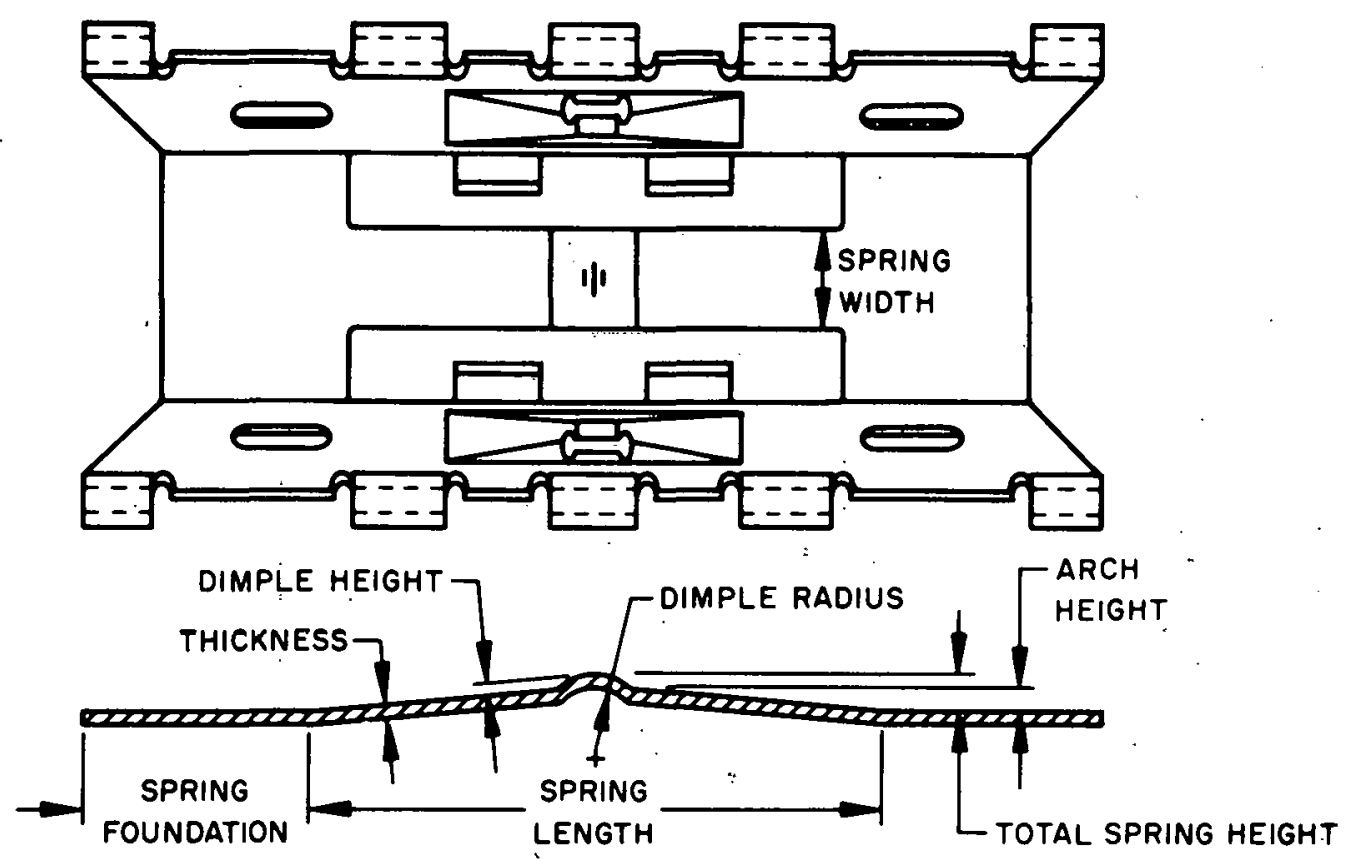

\begin{tabular}{|c|c|c|c|c|c|c|c|c|}
\hline GRID & $\begin{array}{l}\text { NOMINAL } \\
\text { THICKNESS }\end{array}$ & $\begin{array}{l}\text { SPRING } \\
\text { LENGTH }\end{array}$ & $\begin{array}{c}\text { FOUNDATION } \\
\text { LENGTH }\end{array}$ & $\begin{array}{l}\text { SPRING } \\
\text { WIDTH. }\end{array}$ & $\begin{array}{l}\text { TOTAL } \\
\text { HEIGHT }\end{array}$ & $\begin{array}{l}\text { ARCH } \\
\text { HEIGHT }\end{array}$ & $\begin{array}{l}\text { DIMPLE } \\
\text { HEIGHT }\end{array}$ & $\begin{array}{l}\text { DIMPLE } \\
\text { RAOIUS }\end{array}$ \\
\hline SEED & .0135 & .810 & .295 & .090 & .049 & .021 & .028 & .064 \\
\hline BLANKET & .0140 & .800 & .300 & .208 & .050 & .032 & .018 & .065 \\
\hline $\begin{array}{c}\text { REFLECTOR } \\
\text { (BASIC) }\end{array}$ & .0180 & 1.200 & .300 & .220 & .062 & .042 & .020 & .100 \\
\hline $\begin{array}{c}\text { REFLECTOR } \\
\text { (WIDE) }\end{array}$ & .0180 & 1.200 & .300 & .375 & .062 & .042 & .020 & .100 \\
\hline $\begin{array}{c}\text { REFLECTOR } \\
\text { (NARROW) }\end{array}$ & .0150 & .800 & .605 & .150 & .056 & .037 & .020 & .100 \\
\hline
\end{tabular}

Figure 20. Design Dimensions of LWBR Grid Springs 


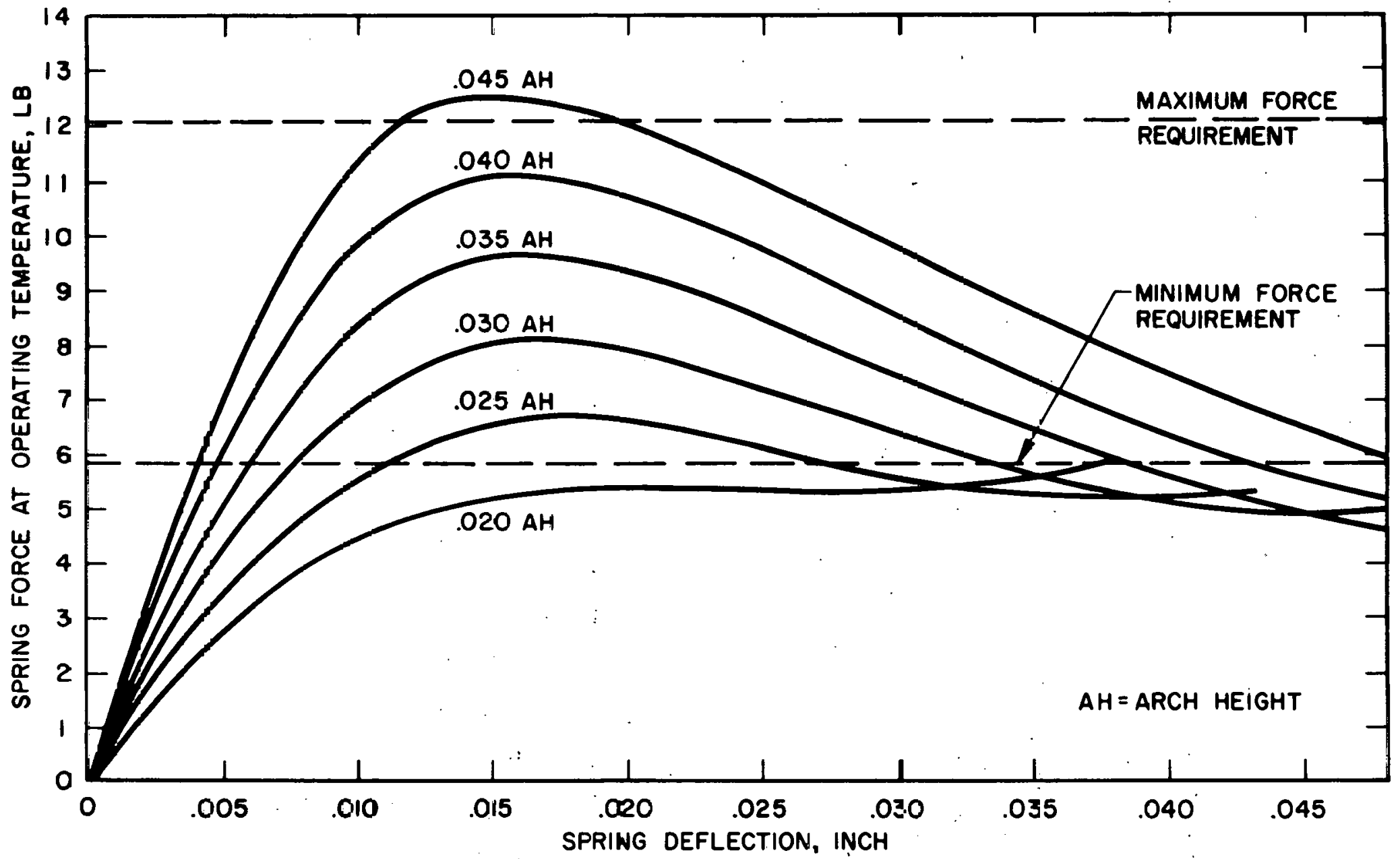

Figure 21. Typical Blanket Grid Spring Force - Deflection Curves for Several Spring Arch Heights 


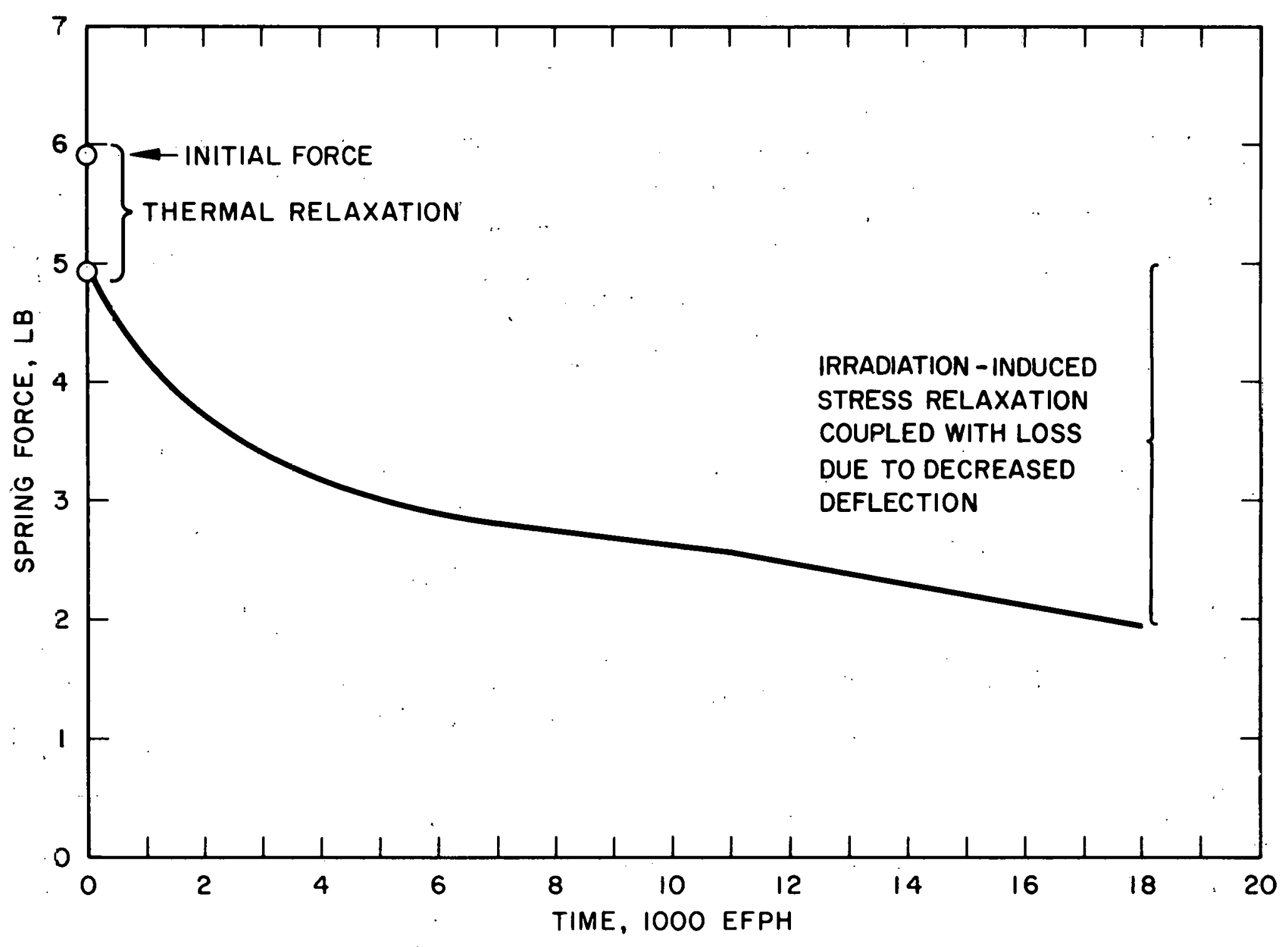

Figure 22. Typical Change in Blanket Spring Force 


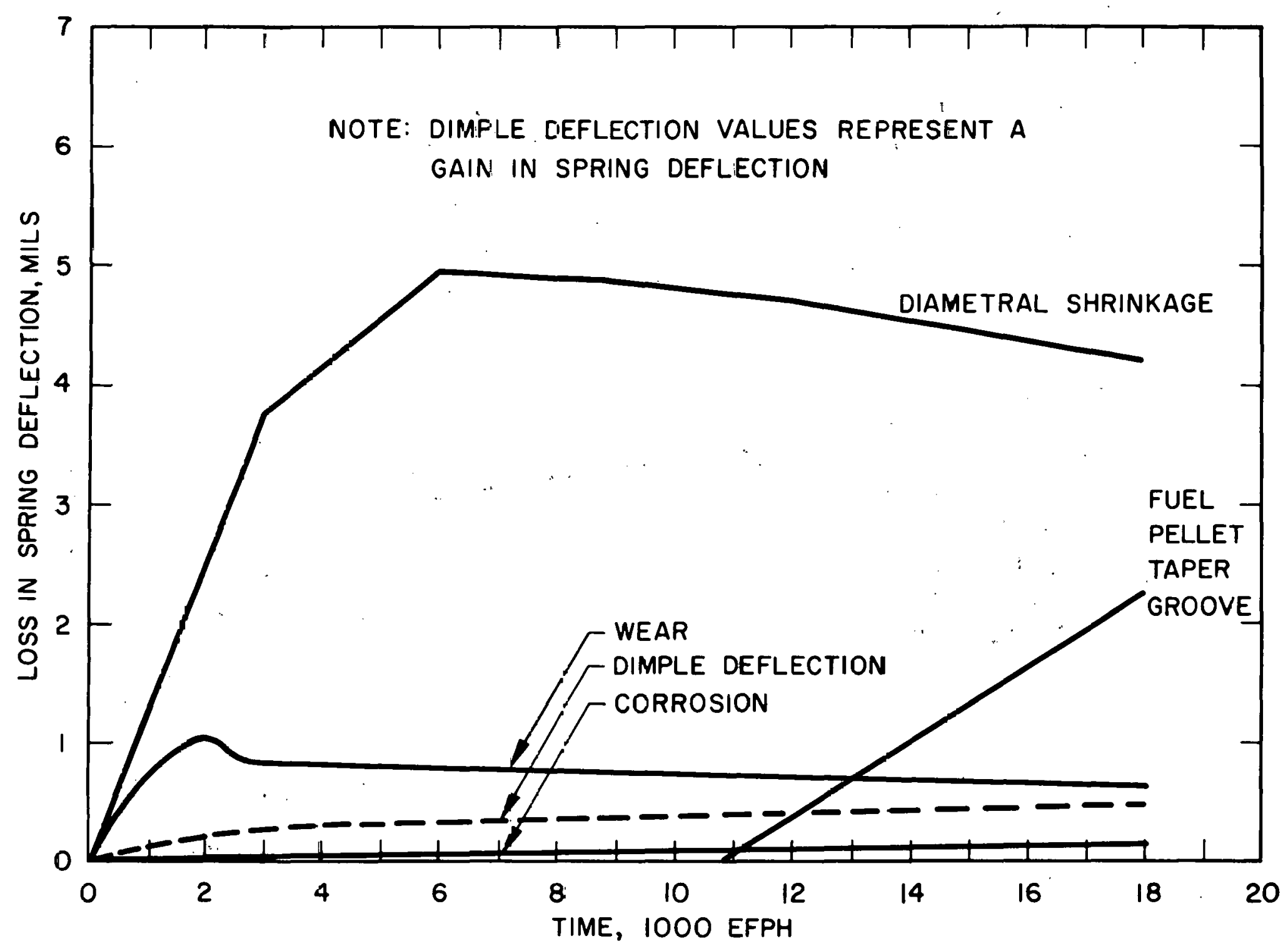

Figdre 23. Typical Contributions to Spring Deflection Loss 


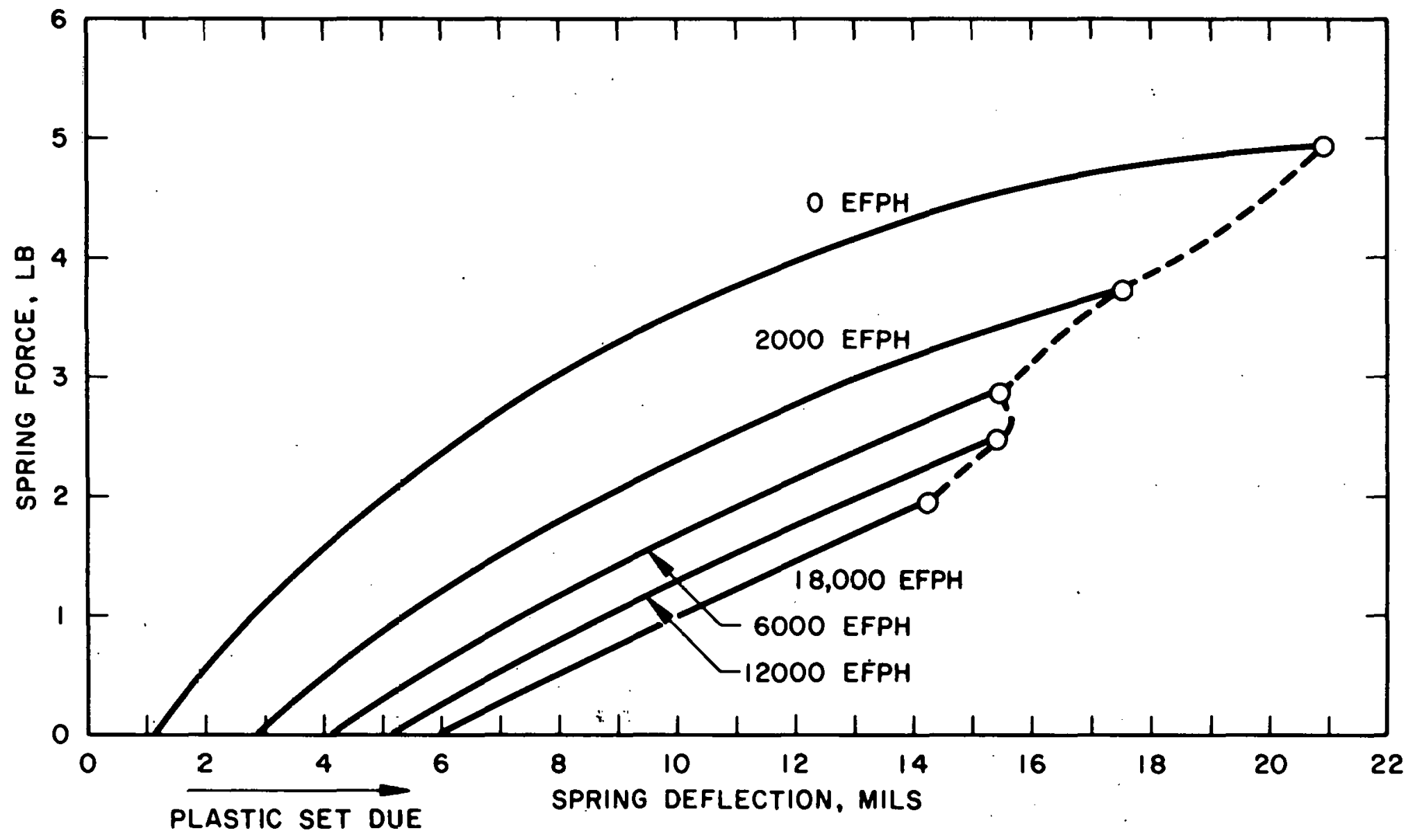

TO STRESS RELAXATION

Figure 2t. Typical Blanket Force - Deflection Curve Changes 


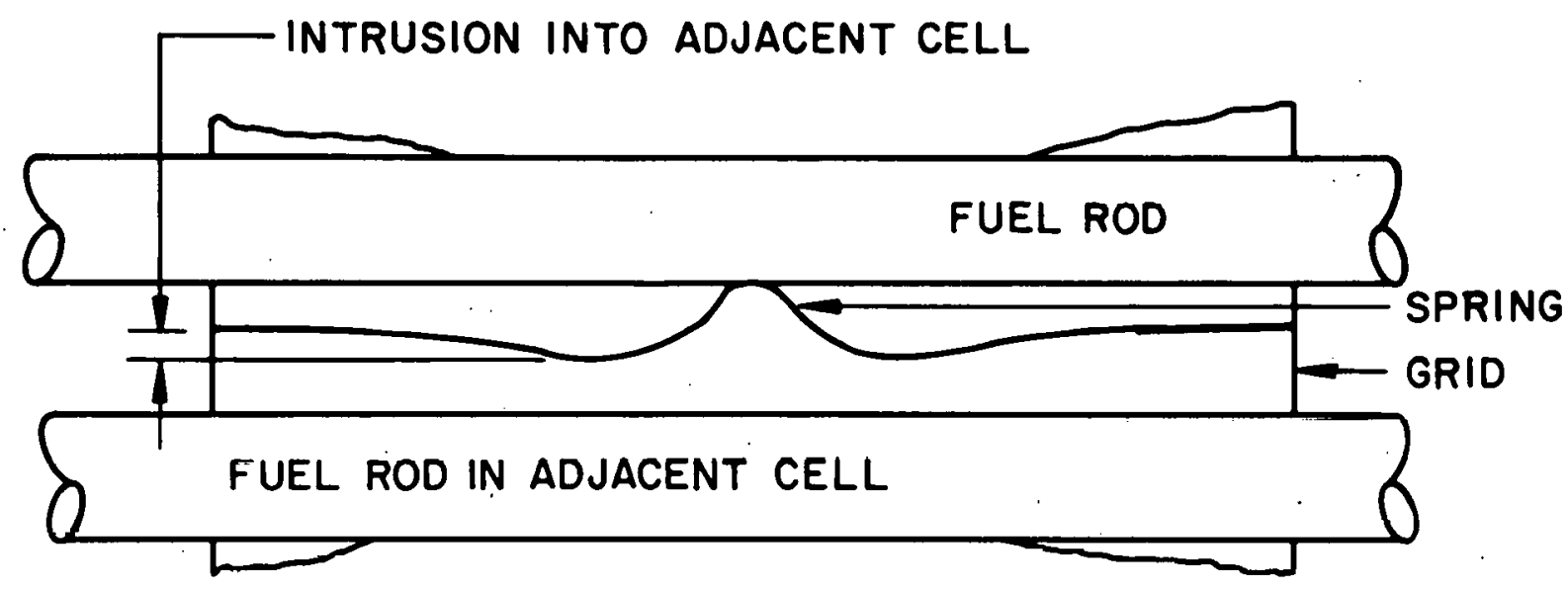

Figure 25. Deflected Spring Profile - Symmetrical Response

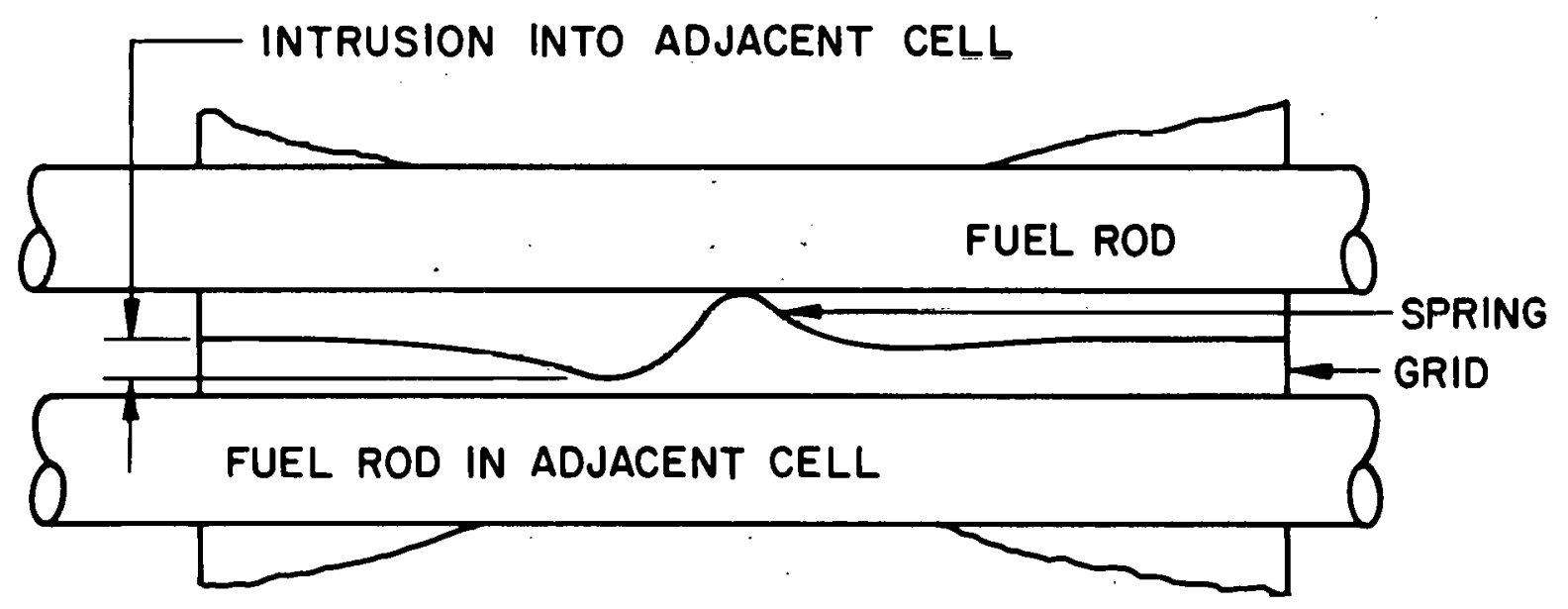

Figure 26. Deflected Spring Profile - Asymmetrical Response 


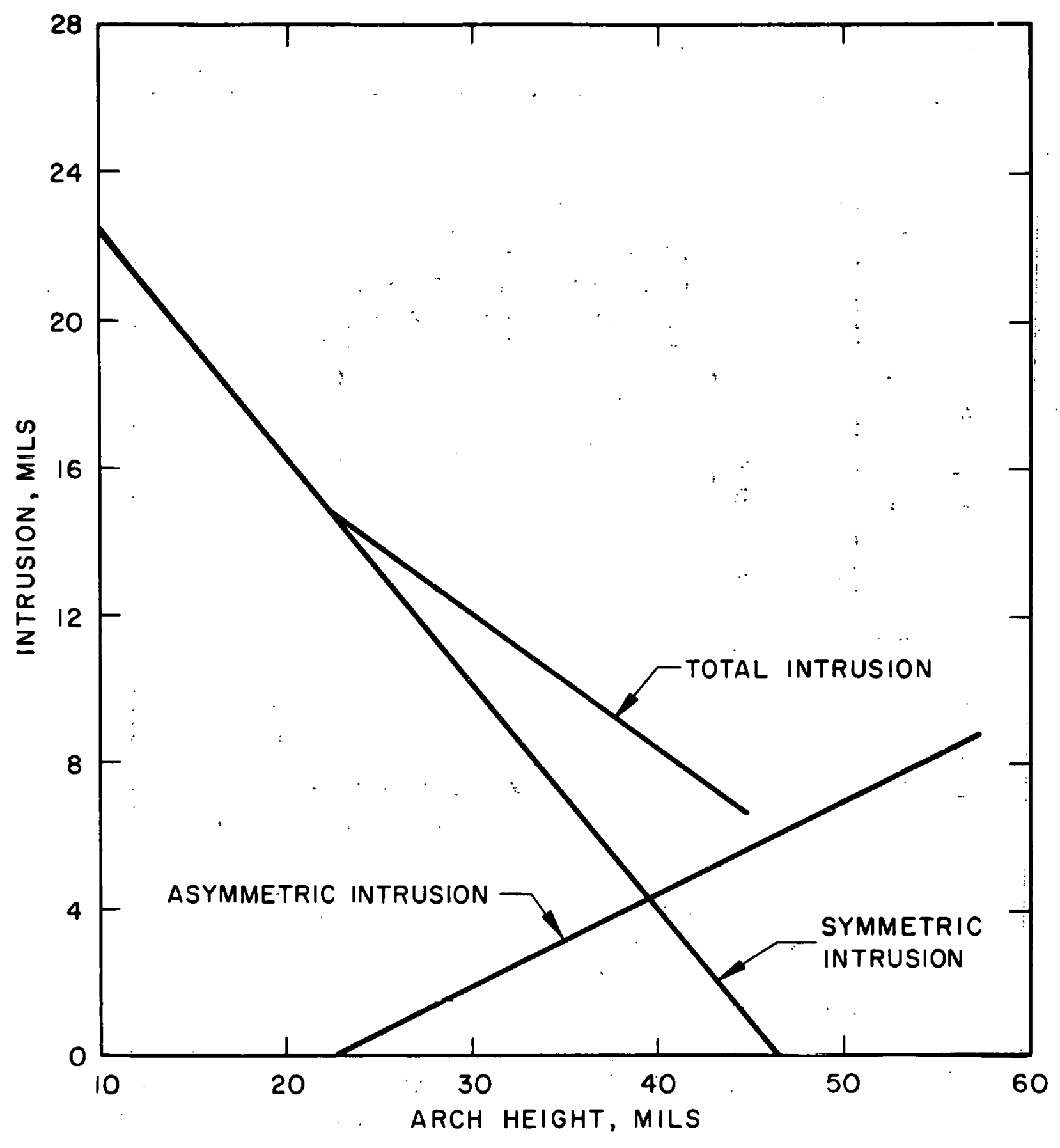

Figure 27. Symmetric, Asymmetric, and Total Intrusion at a Spring Deflection of $35 \mathrm{Mils}$ 


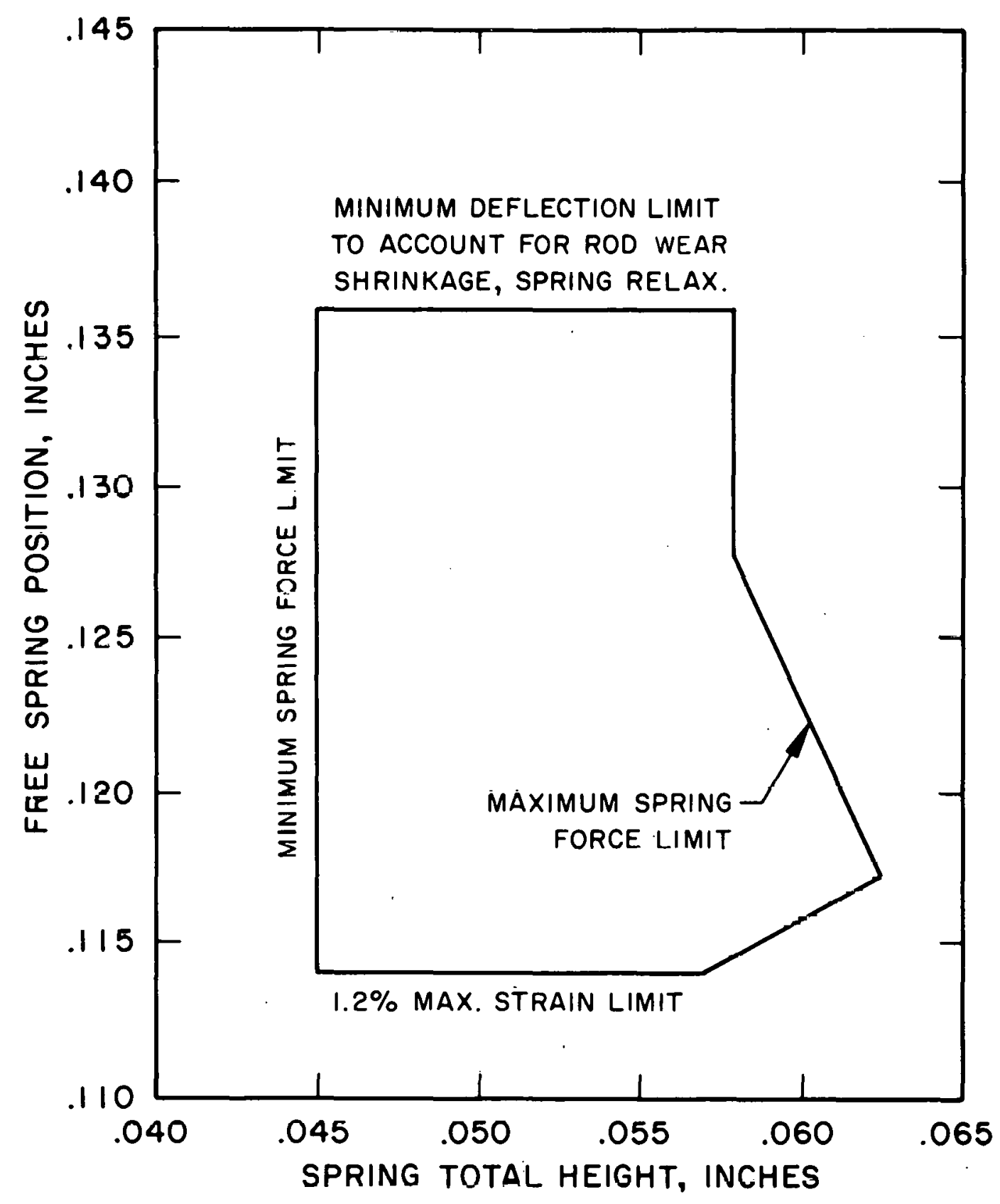

F1gure 28. Spring Parameters Tolerance Envelope for Seed Grid Springs 


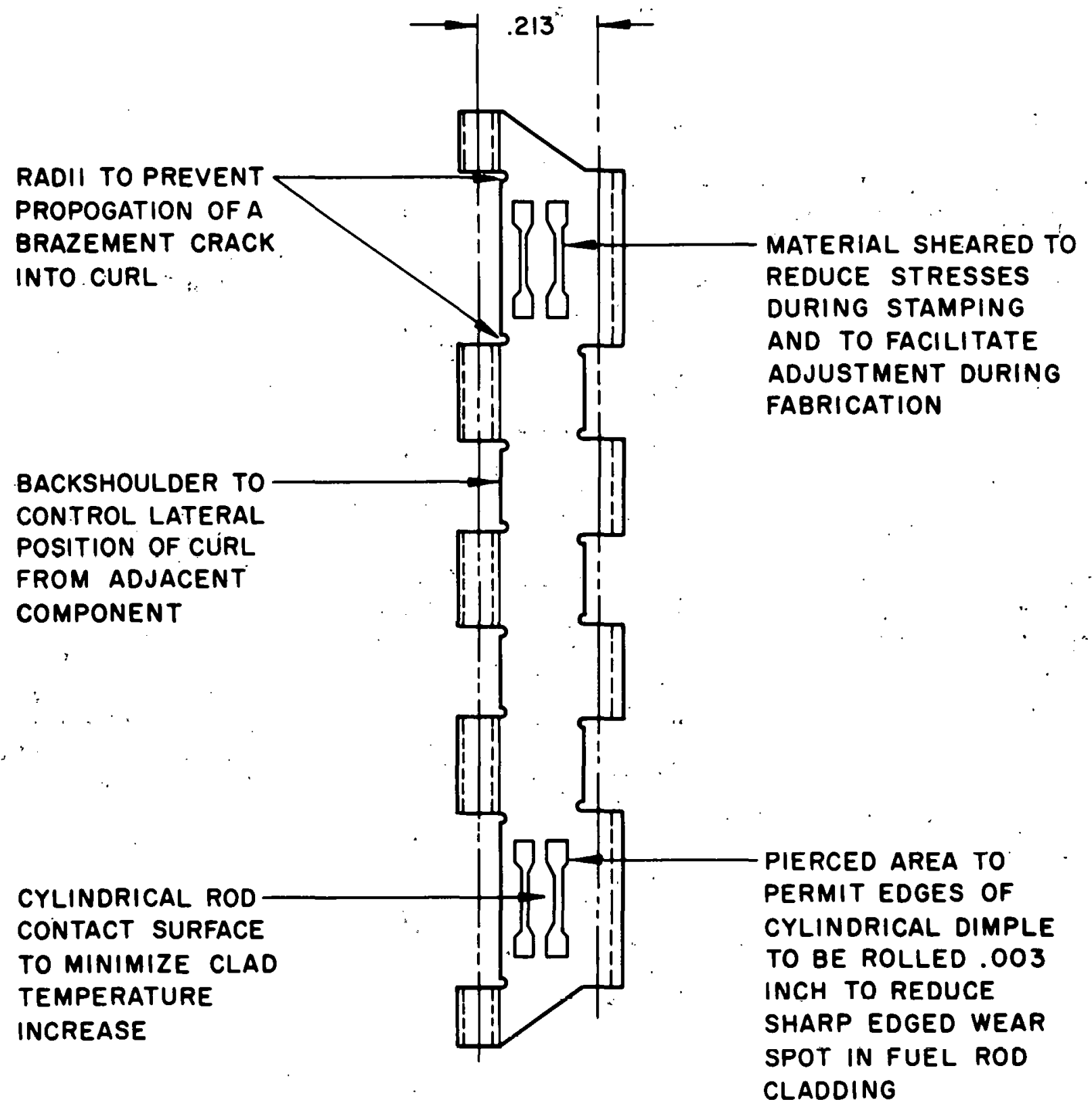

Figure 29. Typical Dimple Panel Section of a Seed. Grid 3-Sided Component 


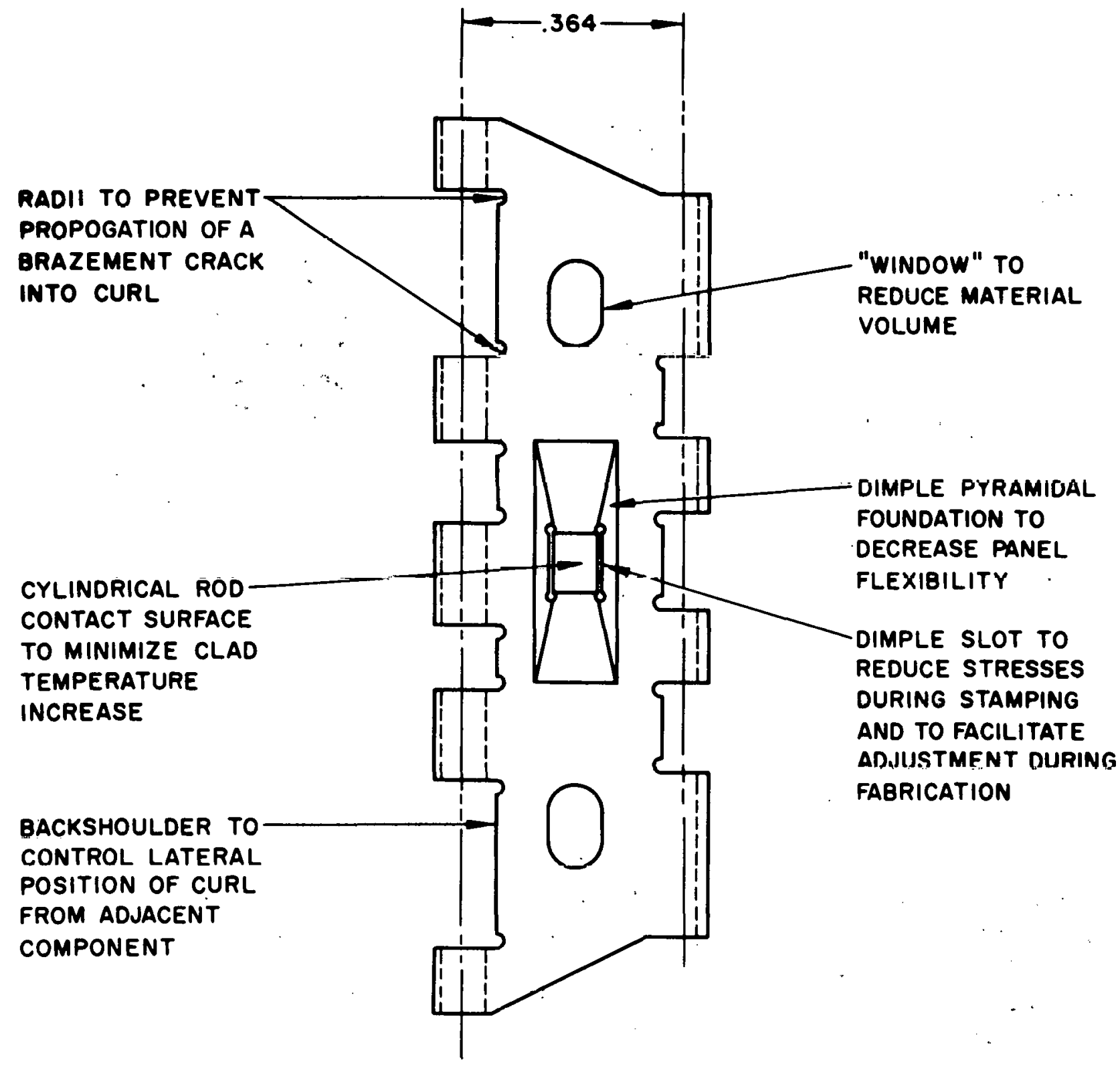

Figure 30. Typical Dimple Panel Section of a Blanket Grid 3-Sided Component 

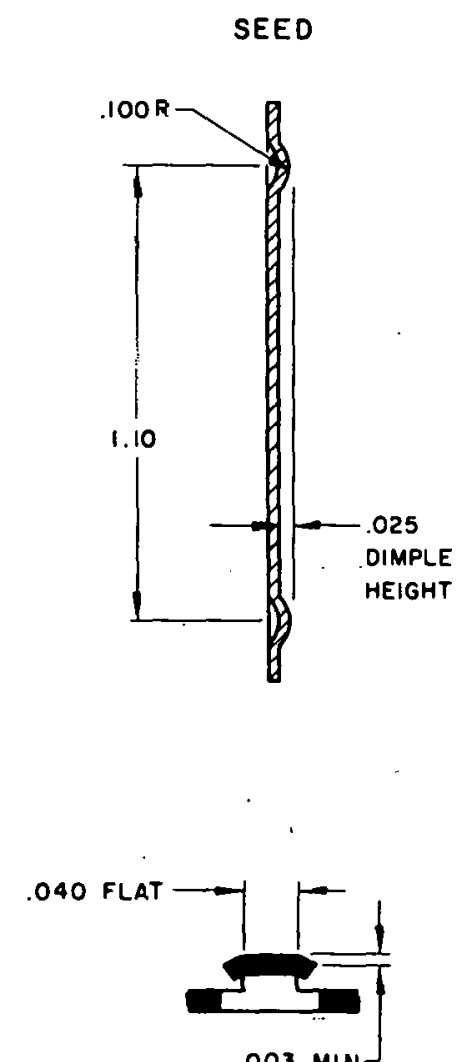

TO ELIMINATE SHARP EDGED WEAF. SPOT IN ZIRCALOY CLAD

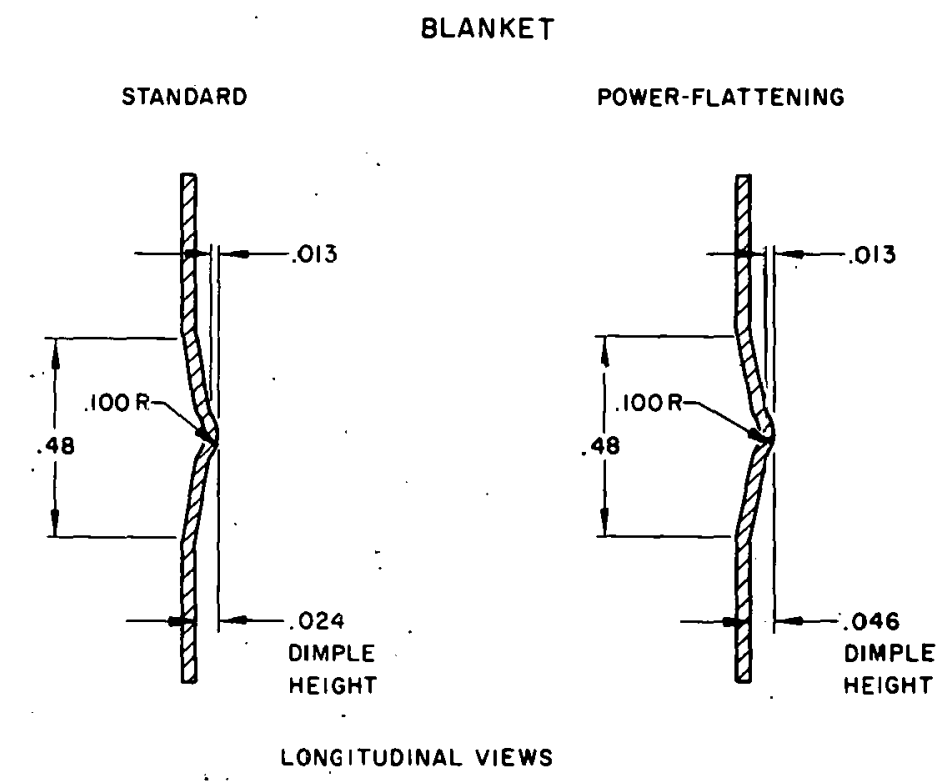

REFLECTOR
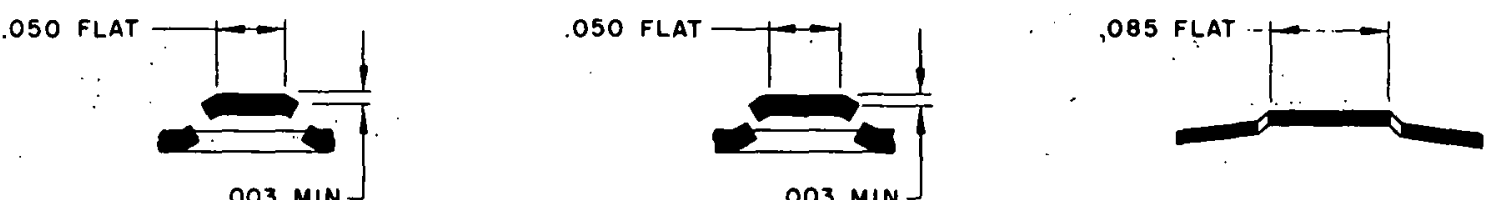

TRANSVERSE VIEWS

Figure 31. Cross-Sectional Views Through Crid Dimples. 


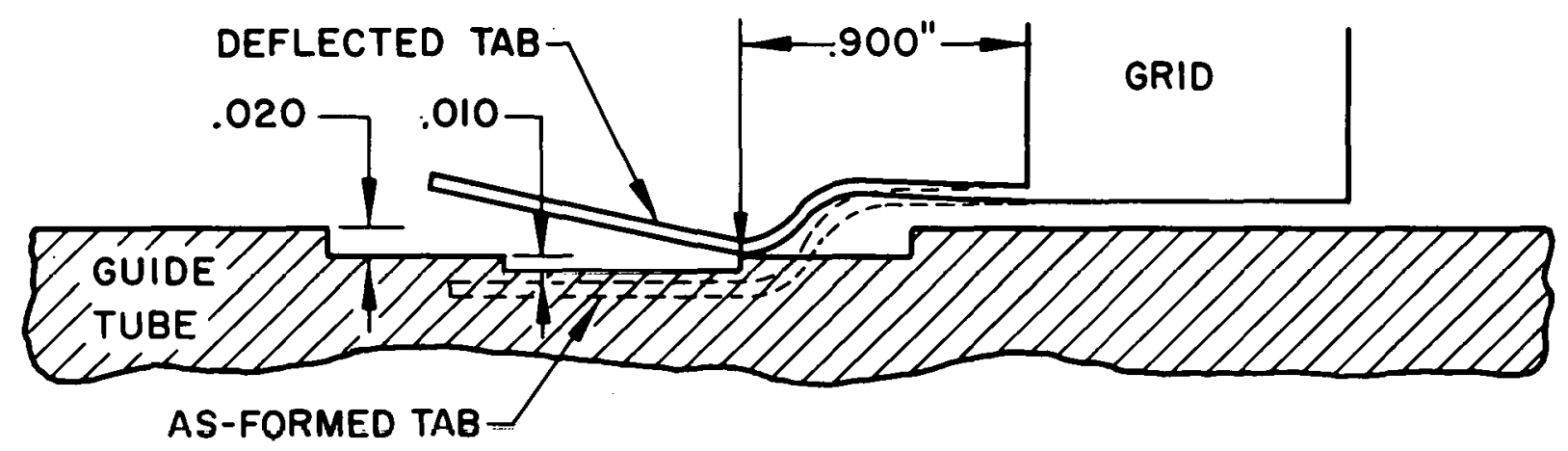

DEFLECTION DURING AXIAL POSITIONING OF GRID ON GUIDE TUBE

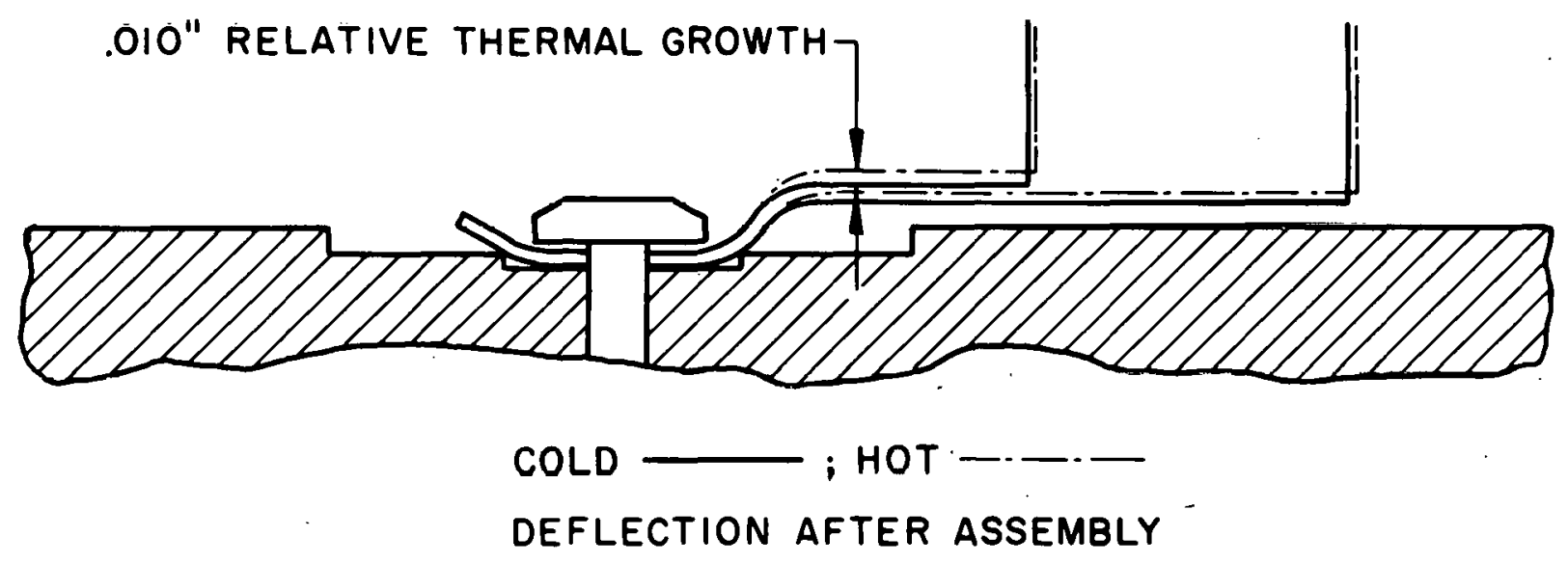

Figure 32. Grid-to-Guide Tube Connection 


\section{APPENDIX A - GENERAL DESIGN CONSIDERATIONS}

Certain physics, thermal-hydraulic, and fuel rod requirements of the LWBR core imposed design requirements on the support grids. A catalogue of these core requirements and the manner in which these requirements were satisfied by the grid design are presented below in Table A-l.

\section{TABLE A-1. GENERAL GRID DESIGN CONSIDERATION'S}

\section{Core Requirement}

\section{Physics}

A. Maximize the breeding potential by placing rods in a tightlyspaced triangular array.

B. Maximize the breeding potential. by reducing parasitic capture of neutrons in the grid structure.
Method of Implementation by Grid Design
A.1. Thin walled $(0.0135$ to 0.018 inch) hexagonal-shaped grid cells fermitted rods to be closely spaced.

2. Brazed grid structure imparted rigidity and dimensional stability.

3. Cell-to-cell pitch dimensions were tightly toleranced ( +0.012 , -0.007 ) to meet minimum rod-torod gap limits of $0.009,0.011$, and 0.013 inch in the seed, blanket, and reflector assemblies, respectively, at any time during core life (Reference 1 ).

B.1. The grid material (AM-350 stainless steel) has a neutron-capture cross section among the lowest of any non-Zircaloy material tested.

2. The use of AM-350 having a high tensile strength permitted thinwalled frids to minimize the volume.

3. "Windows" were stamped into the blanket and reflector dimple panels to reduce material volume. 
Core Requirements

C. Minimize the water volume to prevent local power peaking.

II. Thermal-Hydraulic

1. Minimize contact of grid with fuel rods to prevent cladding hot. spots.

B. Minimize flow-induced fuel sud viuraliun.

A.1. Ruds made contact with grids at fixed dimples and spring only.

2. A cylindrical dimple contact. surface having a 0.100-inch radius was determined to bc thermally desirable.

3. A cylindrical dimple was placed at the midpoint of the spring to minimize contact with the rod.

4. Dimple heights wrro established to place the rod in the center of the cell to provide uniform coolant f:low.

5. Mininum rud-lu-grld wall clearances were specified (see Appendix C).

B.1. Springs were designed to develop and maintain surficient force to keep rods scated on the fixed. dimples at all times.

2. Multiple grid levels were eimployed lic) . I mlt vibration.

3. Nonuniform span lengths between the grid levels were specified to eliminate rod natural frequency of vibration amplification. 
C. Minimize the pressure drop across the grids.

\section{Fuel Rod Characteristics}

A. Accommodate elongation of the cylindrical fuel rods.

NOTE: The fuel rods increase in length during core life and experience expansion and contraction during power transients. The total axial elongation over reactor lifetime may be over 1 inch over the 10-foot long rods (Reference 2).
Method of Implementation by Grid Design

4. The amount of "intrusion" of a spring into the adjacent cell: was limited by minimum clearance requirements to prevent lift off of the adjacent rod from its dimples.

C.l. The grid walls and spring axes were set parallel to coolant flow.

2. The grid wall thickness was set at the minimum possible to maintain structural adequacy.

3. The number of grids in a module was minimized to that which satisfied the rod bowing and vibration limits, to minimize: the tolal pressure drop over the module length.

A.1. The rods are clamped (seed) or pinned (blanket and reflector) against fixed dimples by a flexible spring, permitting the rod to elongate:

2. A maximum spring force limit was specified to limit the axial thrust due to frictional interaction between the growing fuel rods and the grid contact points. High axial thrust loads are undesirable since any initial bow of the rod is amplified.

3. Length changes during a power cycle can cause rod wear at the grid contact points. Again, the spring force maximum was limited to minimize reciprocating motion wear of the cladding, since tests indicated that cladding wear increased with increasing spring f'orce. 
Core Requirements

B. Accommodate fuel rod diametral shrinkage.

NOTE: The magnitude of shrinkage is a function of power level, neutron fluence, cladding heat treatment, fuel pelletto-clad inside diameter gap, and fuel diameter to cladding thickness ratio, and hence varies considerably in the core (Reference 2).

C. Accommodate the additional diametral shrinkage of the binary blanket fuel rods due to the presence of fuel pellet tapcrs.

NOTE: The blanket fuel rods were deniened to ineor porate cladding as thin as possible to enhance breeding (the UD to thickness ratio of these nonf'reestanding blanket rods is about 20.5 versus 13.9 for the freestanding seed rods). The cladding creeps under sysleil pressure to make contact with the fuel pellets and in addition deforms into the grooves caused by the presence of tapers. Pellet tapers were 1ncorporated to prevent "ridges" at the pellet interfaces (to minimize cladding tensile stresses)

(Reference 1 ).
Method of Implementation by Grid Design

B.1. The minimum spring deflection was specified to compensate for this loss in deflection due to diametral shrinkage of the fuel rod. The loss in spring deflection is 1.5 times the diametral shrinkage (Figure A-I).

2. The diametral shrinkage can reduce the clearance between the fuel rod and grid panel 4 by half the amount of diametral reduction (even more if the rod is elliptical). (See Figure A-1.) This shrinkage was considered in the establishment of rod-to-grid elearance (Table $\mathrm{C}-1$ of Appendix C.) .

C.1. Fucl rod cladding grooves result in a spring deflection loss equal to 1.5 times the effective reduction in diameter. The initial amount of spring deflection was established to accommodate this loss in deflection (Figure $\Lambda \cdots$ a).

2. The grooving can also result in a reduction in clearance between the f'uel rod and grid panels 3, 4, and 5. This potential reduction was considered in setting the minimum rodto-grid proximity limits for vlanket grias. 
Core Requirements

D. Control fuel rod bowing to meet the minimum rod-to-rod clearance limits necessary for heat transfer reasons.
Method of Implementation by Grid Design

D.1. The minimum spring force limits were established to minimize the magnitude of bowing and to keep the rods seated on the dimples.

2. The amount of misalignment of: the grid cell centerlines in axially adjacent grid levels was controlled to minimize rod bowing and to prevent loss of contact of the rod with the dimples. For all grids, the cell centerlines were required to be within 0.015 inch of the theoretically true position. (Even tighter limits were established during module assembly.). For' seed grids, since the two levels of dimples can contribute to rod bowing if the dimples are not parallel to the rod axis: (Figure $A-3$ ), each cell axis was required to be perpendicular to the plane of the grid within 0.003 inch p'er inch. 'l'his: was based on méasurement of the top set of fixed dimples relative to the bottom set of dimples.

3. While shorter span lengths between grid levels would reduce rod bowing, the higher reaction forces due to cell misalignment would require higher spring forces to keep the rods seated on the dimples. The axial spacing between grids was therefore optimized to meet the rod bowing limits while minimizing the spring force requirement.

E. Minimize cladding stresses due to excessive clad wear at grid contact points, and accommodate loss in spring deflection and rod-to-grid clearances due to rod wear.
E.1. Cladding wear produces local thinning and stress concentration, which is dependent on the depth and configuration of the wear spots. The grid dimple widths were made as wide 
Core Requirements

NOTE: Fuel rod wear may occur by the following mechanisms:

1. Scratching of the rod surface by grid dimples and spring during assembly

2. Flow-induced vibratory wear

3. Kcciprocating motion wear due to power level changes

Wear depth for the assembly scratches is less than 0.001 inch. Wear depths for the latter two mechanisms are dependent on epring force, grid levcl, amplitude of axial motion, number of power cycles, and the flow conditions. For LWBR, the maximum wear depth was calculated to be about 0.003 inch.
Method of Implementation by Grid. Design

as permitted by the physical limitations of the ccll to maintain a flat transverse profile (Figure A-4). This profile is maintained for wear spot depths less than about 0.002 inch. The dimple edges of the seed and blanket grids were rolled over by 0.003 inch (below the level of the flat portion) to prevent stress concentrations in the cladding from contacting the vertical edges when tile wear. spot depth exceeds 0.002 inch. (See tranverse wear profile at lower right of pigure A-4.) This was not required for the grid springs because of their greater width.

2. Rod eladding wear results in a loss in spring deflection capability (and hence spring force) by the sum of wear depths at the two dimple panels and the spring. Test observations indicated that the maximum wear depth did not occur at each of the contact points at an elevalion. The loss in spring deflection was a. maximum $n t$ ' $?$ is times the caleulnted wear depth for the par ticular grid level under consideration. The initial deflection requirements of the as-manufactured grids were established to accommodatc this Ioss.

3. Cladding wear results in reduction in rod-to-grid panel clearance equal to the wenr depth at the dimple panels (Panel numbers 3 and 5), and twice the wear depth at Panel 4 (Figure A-5). The proximity limits established for the 
Method of Implementation by Grid Design

as-manufactured grids were established to provide a low probability of contact considering, among other factors, this potential clearance loss due to rod wear.

REFERENCES

1. Shippingport Atomic Power Station Safety Analysis Report for the Light Water Breeder Reactor, Volume 4, Chapter 4, 1975.

2. J. F. Giovengo, "In-pile Dimensional Changes to $\mathrm{ThO}_{2}-\mathrm{UO}_{2}$ Fuel Rods with Non-Free Standing Cladding," WAPD-TM-986, November 1970. 


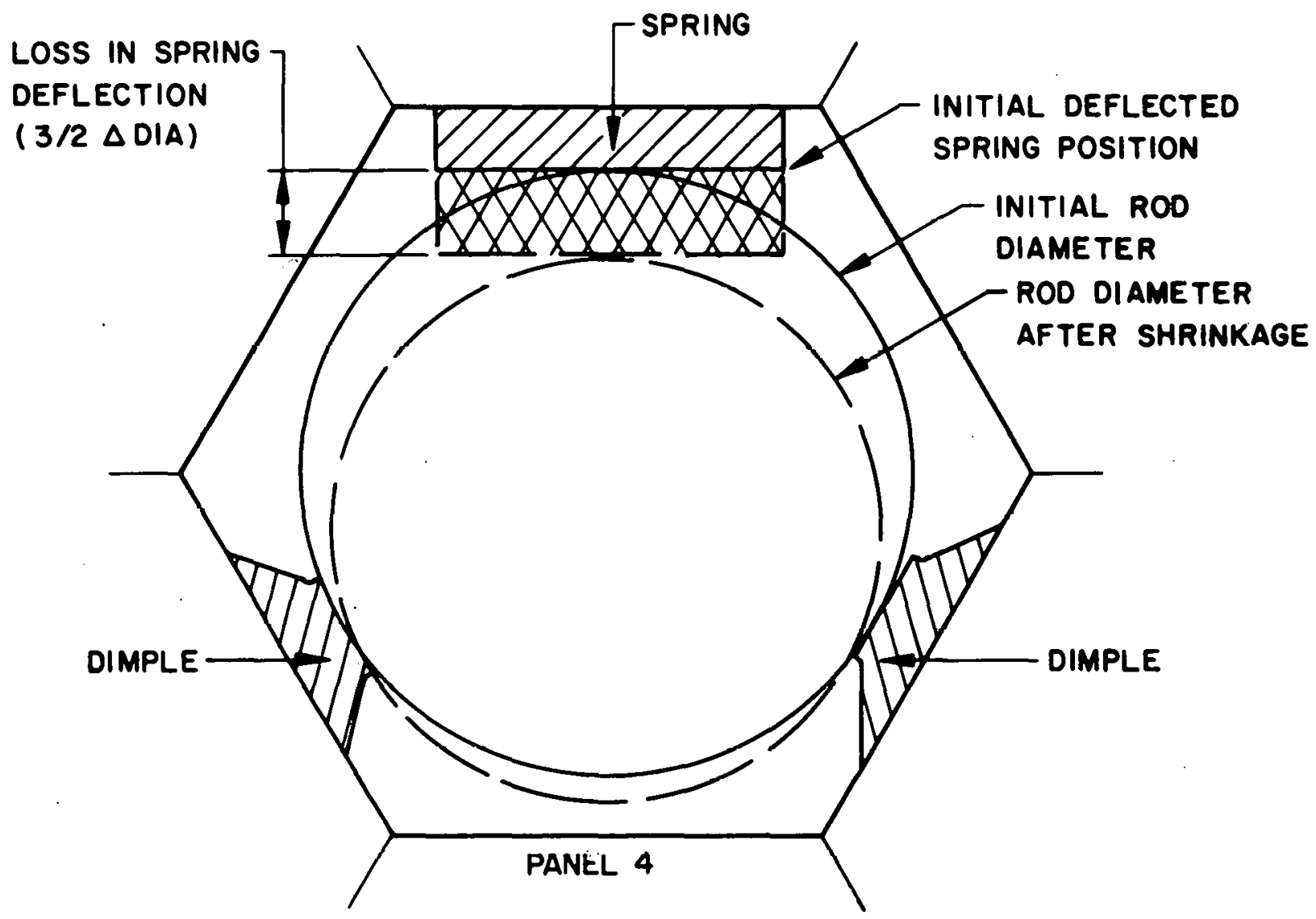

Figure A-I. Loss in Spring Deflection Due Lo Tuel Rod Dilumetrul Ehr"inlsug"c 


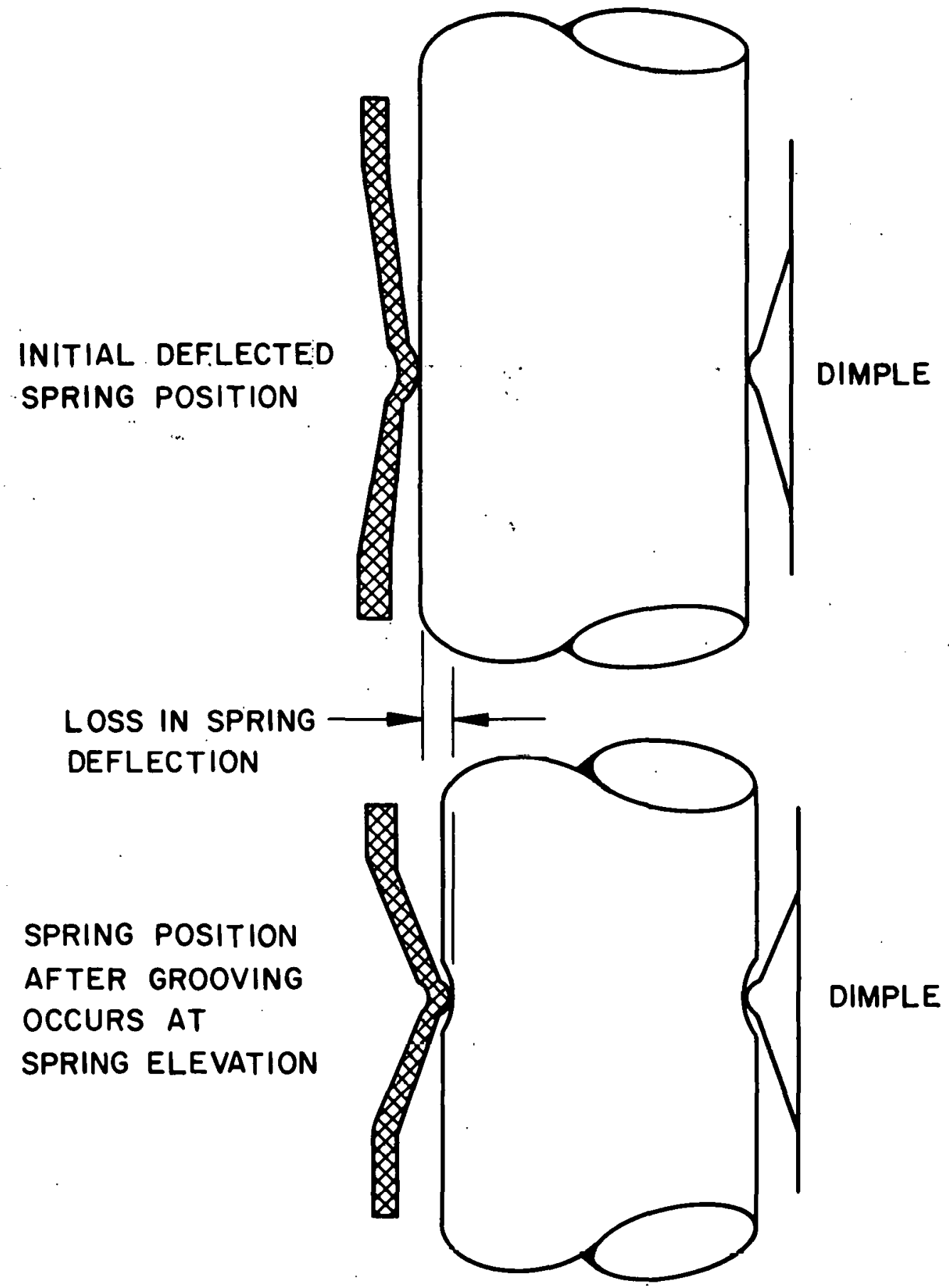

Figure A-2. Loss in Spring Defilection as a Result of Fuel Rod Cladding Grooving 

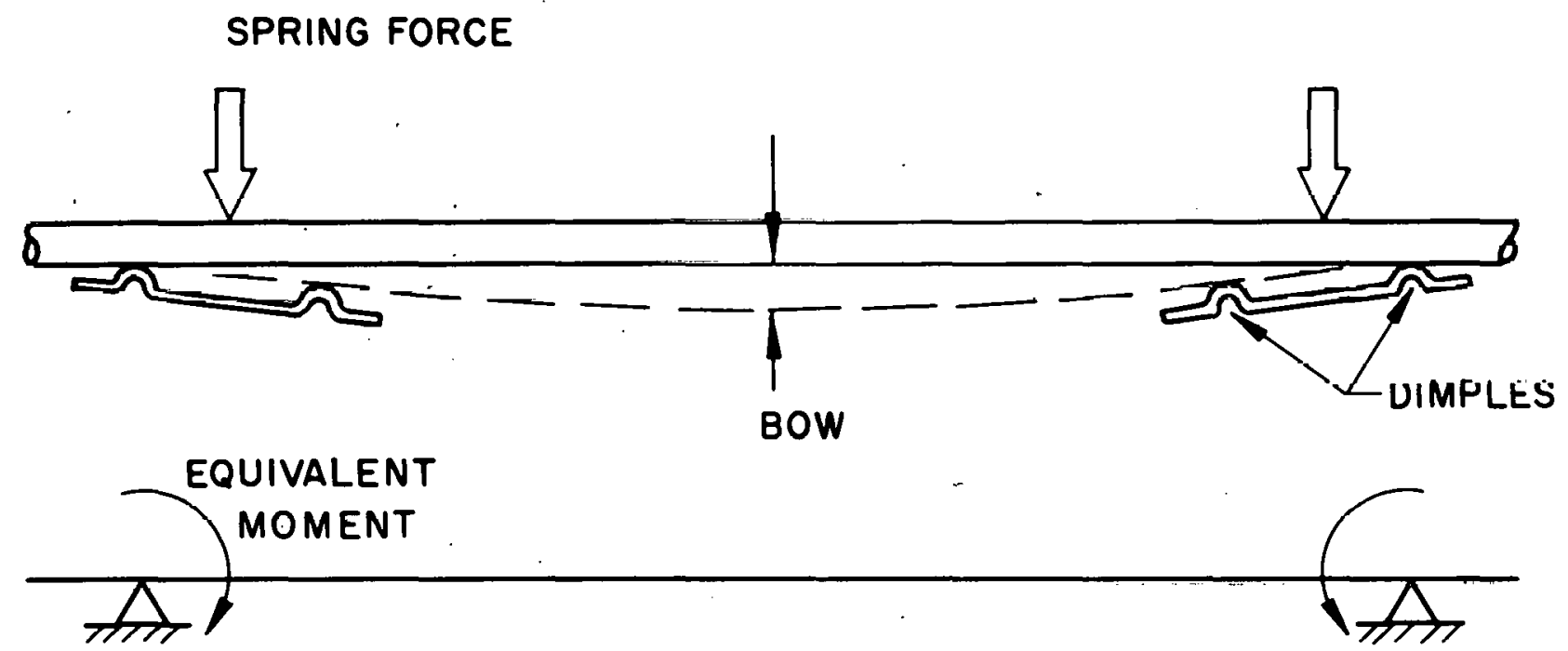

Figure A-3. Bow From Misaligned Dimples in Seed Grids 

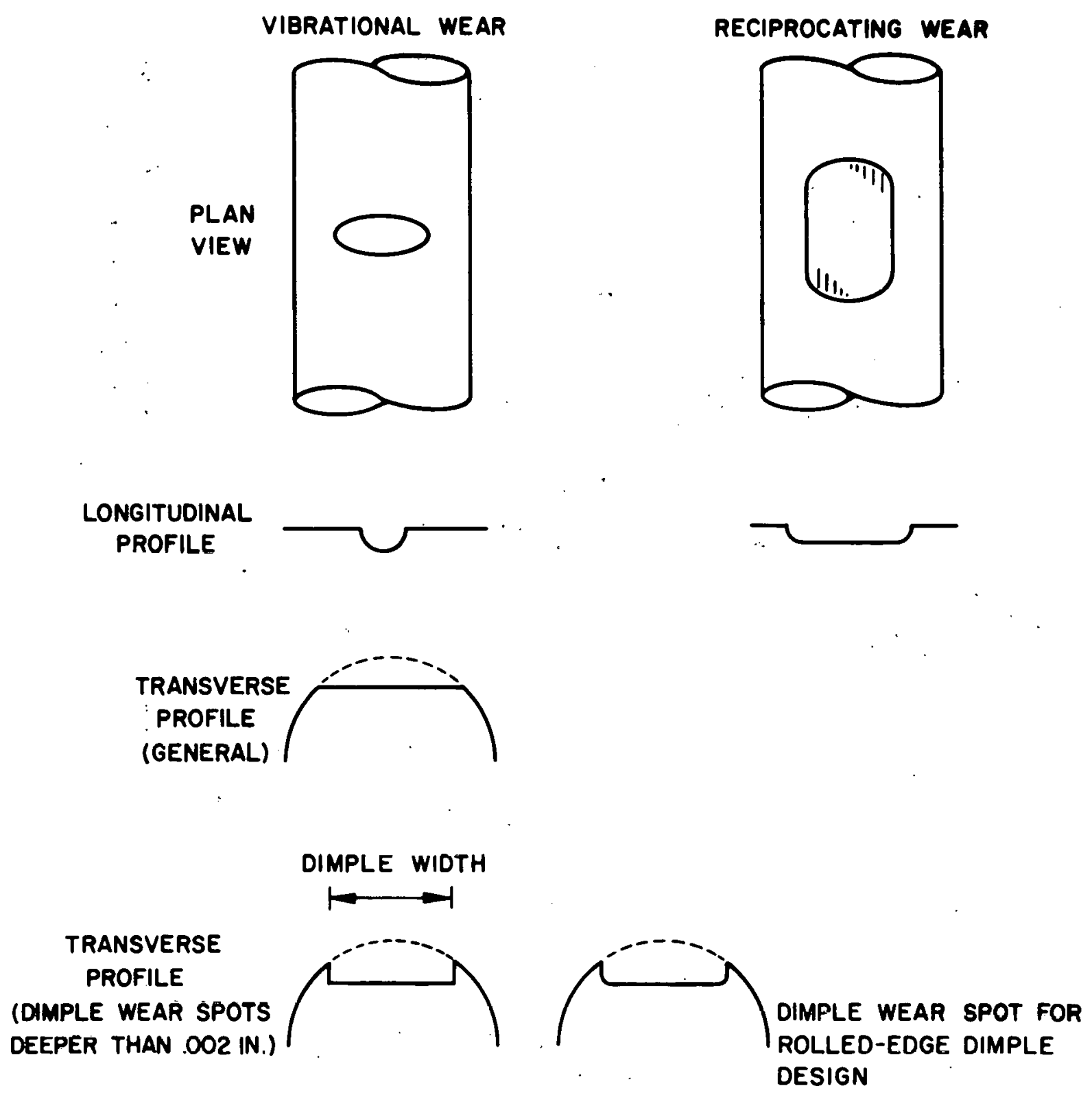

Figure A-4. Fuel Rod Cladding Wear Spot Configurations 


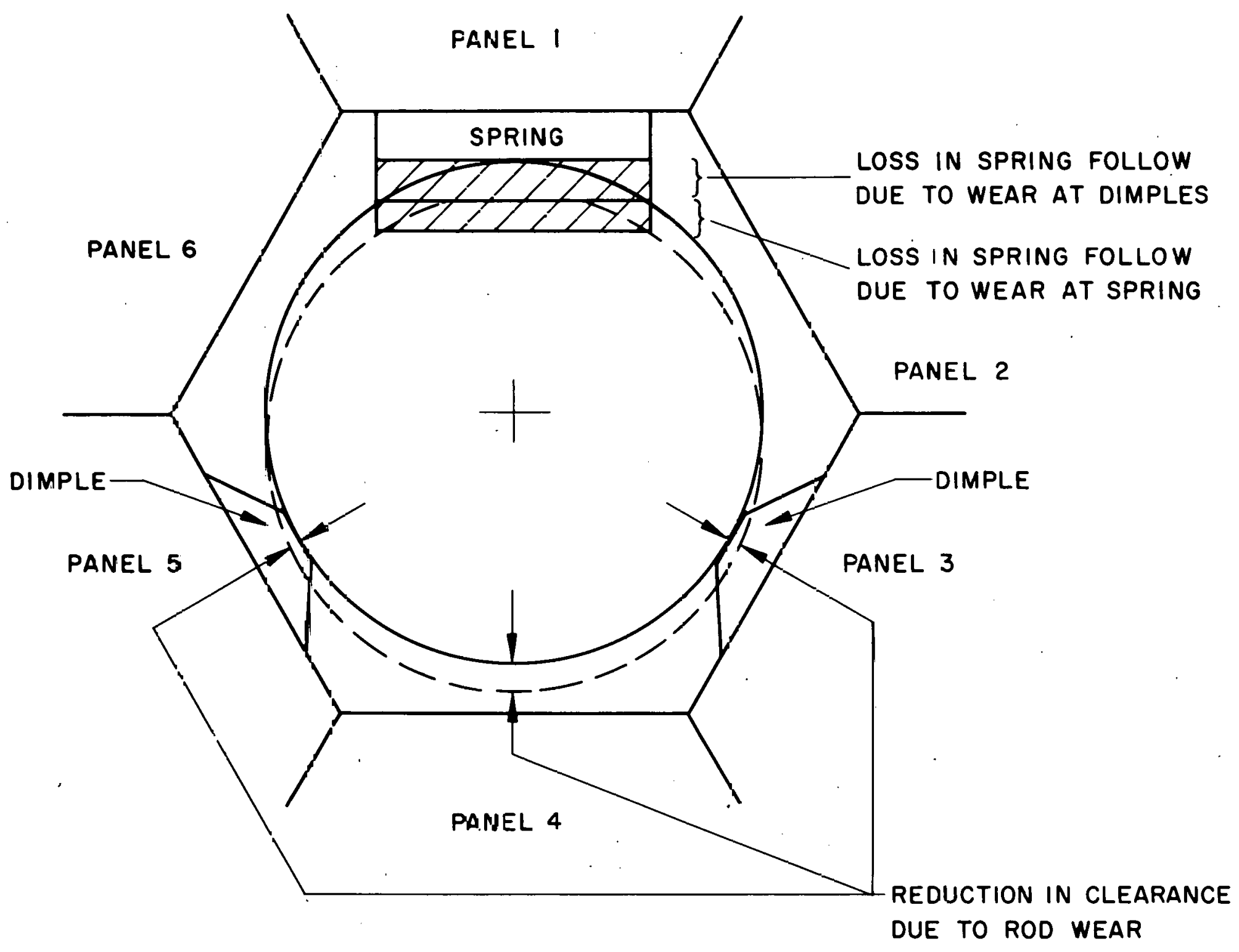

Figure A-5. Reduciton in Rod-to-Grid Clearance and Loss in Spring Follow as a Result of Fuel Rad Wear 
APPENDIX B - STRUCTURAL ANALYSIS METHODS AND GRID LOADING CONDITIONS

Fuel rod support grids must be capable of transmitting loads under all loading conditions without failure. The LWBR grid design had to be adequate in relation to the stresses imposed upon the grid elements under realistic combination of loads, whether static or cyclic. Accordingly, structural analyses of the evolving grid designs were performed to determine whether the stresses in the grid elements were within the criteria established for acceptability. Where a certain grid component did not meet the stress limits, the component design was modified as necessary and additional structural analyses were performed. This iterative process was continued until all components met the design stress criteria under all possible loading conditions. The first section of this appendix describes the analytical methods employed in the structural evaluation of the LWBR grids. The second section describes the major grid loading conditions considered in the structural evaluation.

\section{A. Structural $\Lambda$ nalysis Methnds}

Two computer programs were utilized in performing the detailed stress analyses of the grid elements in each type grid. The first of these was the MDSFP program (Reference 1), originally written at the Denver Division of Martin-Marietta Corporation and modified for use at the Bettis Atomic Power Laboratory. This program solves linear elastic, small deflection, threedimensional structures by the finite element method.. It was used to analyze all loading conditions. For the transient condition's, another structural analysis computer program was employed in conjunction with the MDSFP program. This second program solves the total problem of fuel rod loading and sliding in grids under transient conditions.

In analyzing the structural adequacy of the grids using the MDSFP structural computer program, the grids were assumed to be an assemblage of line (beam) elements intersecting at node points rather than actual panel elements.' Detailed structural variations related to the actual stamped elements could not be simulated with any degree of accuracy within the computer model. The determination of element stresses as determined by MDSFP was therefore not used explicitly; rather, areas and moments of inertia of the individual paneis were specified and related to beam type elements to obtain element stiffnesses. 
The displacements of the grid structure under the various loading conditions were used to calculate forces and moments acting in each element of the grid array, and the stresses produced by these forces and moments. Detailed analyses of each element were then made, accounting for the variations in element geometry including the effects of notches, radii, cutouts, and transitions in cross sections.

Because of computer storage limitations, the entire grid array could not always be modeled in MDSFP. Since the grids were nearly symmetrical about their centerlines, the grids were modeled using the smallest symmetrical section. The seed and Type I blanket grids were modeled using $1 / 12$ segments, while $1 / 2$ segments were modeled for the Type II and Type ITT blanket gride ond Type TV reflector grid. The entire Type $V$ reflector grid was modeled. Since the connectors in the seed and Type III blanket grias were not actually centered on a side, the line of symmetry was offset near the conncctor. Tlie effect it' this offset was found to be small.

The loading on the grids is quite complex. In general,.. the rods lnad the grids through the frictional forces of the rod on the springs and dimples. This frictional force, which is a function of sping force and friction coefficient, may deflect the grid vertically upward or downward, depending on the growth direction of the fuel rod. The force may vary from zero to a maximum, which occurs when the rod slides through the grid contact points, at which time the load would remain cunstant. Since alternate rows of rods were attached to top ur uullom bàse plates, the frictional forces of the rnis, ideally, ncorly cancel out as one row of rods grows vertically downward while the adjacent rows grow vertically upward.

A "pattern loading" scheme was developed whereby fuel rods, both topmounted and bottom-mounted, 1 nrater near the conncctors wire ussumed to be the only rods loading the grids vertically. No benefil was taken tor the fact that the fuel rods may slip through the grid contact points due to different,ial thermal expansion during transient conditions. The grid loads colculat.ed for transient conditions were therefore unrealistically high. To overcome this overly conservative assumption, the second structural analysis computer program was used. This program had the capability of permitting the fuel rods to slide through the grids. Caclulations were made by this program to determine whether 
the rods were sliding due to the frictional interaction forces between the thermally expanding rods and the grid contact points. The resulting total loads on the grids were significantly reduced by this more realistic assumption. The Inats on the individual grid components were then reduced from those calculated by the MDSFP-pattern loading scheme by the ratio of the total grid load calculated by the second computer program to the total grid load calculated solely by the pattern loading scheme. This ratio is of the order of $1 / 3$ to $1 / 2$. Therefore, the transient loads on the individual grid components are significantly reduced from those calculated by the pattern loading method.

Because all loads must be transmitted either into the grid through the connecting members or from the grid into the adjoining structures through the connectors, the largest forces and moments were found to be concentrated in the regions immediately around the connectors. The limiting elements were therefore those directly attached to the connectors, since the number of those elements is small compared to the total number of elements in the grid. Consequently, the loads are concentrated in these few elements. Detailed analyses of these limiting elements were then performed to confirm the structural adequacy of the support grids.

The grids were also analyzed for in-plane buckling loads. A conservative limit of buckling for each grid panel within the elemental array was established. The in-plane compressive loads had to be a factor of 3 below the Euler buckling load for panels with hinged ends.

Loads imposed on the grids from the conditions described in the next section were evaluated, and the resulting stresses were categorized as to whether they were primary (due to following-type loads) or secondary (deflection-limited type loads). Steady-state operating loads associated with hydraulic loads across the grids, and fuel rod growth-induced loads, were considered as primary loads.. Stresses arising from these loads were combined with the stresses from each. accident condition taken separately. They were then compared against the primary stress limits. These limits were based on the AM-350 grid material or braze alloy mechanical strength values, shown in Table 3 of the text:

Secondary stresses arising from deflection-limited conditions were combined with the primary stresses to determine the maximum range of stress the grid elements would experience when subjected to all of the loads described above. 
Contributions to this grid stress intensity during the limiting cyclic loading conditions are shown schematically in Figure B-l. Stresses from the limiting stress cycle, when increased by the appropriate strength reduction factors to account for stress concentration due to geometry effects such as notches, cutouts, and transitions in cross section, defined the peak stress intensity range for use in the fatigue evaluation.

In evaluating the adequacy of the grids with respect to fatigue, the calculated stress intensity range (2Sa) was used in conjunction with the applicable fatigue design curve to determine the allowed number of cycles. Where the grid element being evaluated for fatigue was solely of AM-350, the applicable fatigue curve I-9-1 from Section III of the ASME Boiler and Pressure Vessel Code was employed. Where the grid element being evaluated was a brazed joint, however, the fatigue curve (Figure B-2) devcloned from actual test data of irradiated AM-350 brazed sperimens, was employed. The allewed numiber uf cycles so determined was compared with the required number of cycles specified for core lifetime. The fractional damage attributable to cyclic conditions was determined as the ratio of the number of cycles required to the number of cycles allowed. This ratio, termed the Fatigue Usage Factor, $u$, was calculated for the two cyclic loading conditions encountered during core operation. These two stress cycles are:

1. A pressure-power cycle involving a heatup and cooldown of the corc (from 7OF to 53IF). This necessitates a pressure nhanee (from 200 to $2000 \mathrm{pci}$ to preclude lillle fracture damage to the reactor vessel (30 pressure-power cycles are required).

2. A power cycle involving a power increase and decrease (1065 power cycles in addition to the 30 pressure-power cycles are required.).

The acceptance criterion for assessing the cyclic adequacy of the grids was that the tractional damage attributable to the two cyclic conditions must he kept below 1.0 .

B. Grzd Loading Conditions

The major loading conditions imposed on the grids and included in the structural analyses were:

1. Installation loads occuring during module assembly

2. Steady-state operating loads 
3. Transient loads, including both power transients and pressure-power. transients (plant heatup and cooldown cycle)

4. Accident conditions

5. Module shipping loads.

A discussion of each of these loading conditions is presented.

1. Installation Loads

Three sources of loads imposed on the grids were directly associated with core module assembly. The first of these installation loads was the vertical load on the grid which developed when each fuel rod was inserted through the grid cell. This load was negligibly small as each previously inserted rod acted as a vertical support for the subsequently inserted rods.

A second type of installation load was the internal lateral cell load resulting from rod-to-spring interference and its reaction at the fixed dimples. The reaction load at each dimple sidewall (and spring wall) was equal to the spring force in that cell, by virture of the 120 degree angular spacing of the dimples and spring. The analysis considered that a nominal spring force (about 4.0 pounds in the seed, 8.4 pounds in the blanket, and 8.7 pounds in the reflector) existed in all cells throughout the core life. (Actually, the loads decrease due to stress relaxation of the AM-350 grid material.) Stresses from these loads. were limited by the amount of interference between the spring and fuel rod, and as such, were grouped in the category of primary plus secondary stresses.

This type of load also contributed to the in-plane growth of the grid which was resisted by the attachment to the support posts and shells. An interaction load was thereby imposed on the grid at the connectors, resulting in secondary stresses. The in-plane growth was small, on the order of 1 to 2. mils, as measured from the grid center. These calculated in-plane growth values were confirmed by measurements taken before and after rod installation in a test bundle.

The third type of installation load was the interaction lateral load caused by the attachment of the grid to its support structure. Accommodation of clearances between the two led to deflection-induced loads, resulting in secondary stresses due to the deflection-limited nature of these loads. The interaction 
force was a function of the spring constants of the grid and shell and the maximum radial clearance between the two, as given by

$$
F=\frac{K_{g} \times K_{s}}{K_{g}+K_{s}} \delta i
$$

where

$$
\begin{aligned}
F= & \text { the interaction force on the grid connector, acting perpendicularly to } \\
& \text { the grid boundary in an outboard sense } \\
\mathrm{K}_{\mathrm{g}}= & \text { grid spring constant } \\
\mathrm{K}_{\mathrm{S}}= & \text { shell sprinf constant } \\
\delta_{\mathrm{i}}= & \text { maximum radial clearance between grid and shell. }
\end{aligned}
$$

The maximum interaction load was calculated by this method to be on the ordcr of 40 to 50 pounds at the connectors at room temperature for seed and reflector grids. Blanket grid connectors were not subject to this type of load, since the blanket support posts were not bolted to a shell as in the seed and reflector modules. Clearances were reduced at core nerating temperaturc by virture of the greater coefficient of thermal expansion of the AM-350 grids relative to the Zircaloy-4 post-shell assembly, thus reducing these interaction forces.

\section{Steady-State Operating Loads}

Steady-state operating loads were the result of the flow-induced pressure drop across the grid and the friction interaction load. The friction interdiliun load resulted from the growth of the fuel rods relative to the adjoining Zircaloy support structures to which the grids were attached. Both of these loads were considered as primary loads since they were not self-limiting.

These vertical loads caused vertical deflection of the grid (perpendicular to the plane of the grid). With anproximately half the rodz attached to each base plate, the net vertical load was small. The value of this net verlical load, defined on a statistical basis and combined with the hydraulic load, results in a total primary load given by.

$$
P_{T}=P_{H}+N F u+\sqrt{n}\left[(\Delta F u)^{2}+(F \Delta u)^{2}\right]^{1 / 2}
$$

where

$$
\begin{aligned}
P_{I} & =\text { hydraulic load } \\
N & =\text { difference between number of top- and bottom-mounted rods }
\end{aligned}
$$


$\mathrm{F}=$ average lateral cell load $=3$ times average spring load due to 120 degree circumferential orientation of dimples

$u=$ average coefficient of friction

$\Delta u=$ difference between maximum and average coefficient of friction

$\Delta F=$ difference between maximum and average cell load

$\mathrm{n}=$ total number of cells in grid.

This total load was assumed to be uniformly distributed with an equally imposed transverse load in each cell of the grid. The MDSFP computer program was used to calculate the vertical grid deflections in response to these loads. The resulting stresses in the grid elements were evaluated against the primary stress limits.

3. Transient Loads

a. Power Transient Loads

Axial power distributions were not uniform along the length of the fuel rods. During a core power excursion, grid loads were developed from the power-induced nonuniform temperature distribution along the length of the rods. This resulted in relative axial motion between the rods and the grids. This motion was resịted by the frictional component of the grid spring force, causing vertical deflection of lie grias.

A structural analysis computer program in use at Bettis was employed to define grid loads and axial deflections. Because of the unusual post connector and internal tab connection, this program was used especially for the blanket grias. For these blanket grids, the maximum grid loads at operating temperature were calculated to be less than 2000 pounds, the maximum grid deflection was only ก. 0017 inch, and the maximum loadings on each connector and tab were calculated to be on the order of 183 pounds and 80 pounds, respectively. Mechanical tests with tab, connector, and total grid loads well in excess of these maximum calculated loads (discussed in Appendix $E$ ) have verified the structural integrity of the grids.

\section{b. Pressure-Power Transient Loads}

During major plant heatup and cooldown transients, the grids were subjected to temperature excursions from $70 \mathrm{~F}$ to $531 \mathrm{~F}$ in combination with a pressure change from 200 psi to $2000 \mathrm{psi}$ and a power level change. Every grid experienced a load caused primarily by differences in relative stiffnesses and coefficients of expansion between the AM-350 grid and the adjacent support structures, namely, 
the Zircaloy shells in the seed and reflector modules and the NiCrFe Alloy 600 base plates near the terminal grids. These interaction loads, which were lateral in direction and were imposed on the grid at the connector attachment locations, were calculated by the same analysis method used for the installation clearance loads.

The reflector grids were subject to another type of loading during these pressure-power cyclic loading conditions. The reflector shell does not have pressure equalization holes as does the seed shell. Hence, a differential pressure across the shell wall during a pressure transient would cause lateral shell deformations which, in turn, would cause interaction lateral loads on the grid connectors. These stresses on the grids were included in the calculation of the primary plus secondary stresses. The calculated stresses met the 3 sm stress intensity limits (see Table 3 of the text) for cyclic loading in all grid elements, except for the bottom reflector grids. For these grids the reflector shell deformations due to the pressure differential were calculated to result in a 0.014 inch maximum interference with the grid. Stresses in the limiting opring element in this grid exceeded the $3 \mathrm{Sm}$ limit by approximately 35 percent. Selective placement of smaller grids (based on as-built boundary dimensions) was specified to reduce the maximum interference to below 0.009 inch. The primary plus secondary stress intensity associated with this interference was calculated to be below the $3 \mathrm{Sm}$ limit, and, therefore, was an acceptable structural condition.

\section{Arrident Lodds}

Accident conditions of two main classificalions were considercd in the structural design of the LWBR grid.

a. Increased coolant flow rate and consequently increased hydraulic loads. A loss of coolant accident (LOCA) and a stuck check valve slam accident (SCVSA) were considered in this ca.tegory.

b. Load-induced stresses due to upset conditions, namely reactor scram and seismic shock.

In relation to the first condition above, the maximum increase in the hydraulic loads was considered to occur during a hot-leg LoCA. At this time the friction pressure drop was calculated to be three times the normal pressure drop for seed and blanket grids, and seven times the normal pressure drop for reflector grids. 
In relation to the second condition, the dynamic response of the fuel rods to module deceleration during a reactor scram causes grid deflections. This results in increased loads on the seed. and blanket grids. Based on both calculated and tested values of grid flexibility, the grid deflections were translated into uniformly distributed loads of about 230 pounds on both the seed and blanket grids. Reflector grids are not subject to loads caused by a reactor scram.

With respect to seismic shock, the loads (per grid) from this condition were calculated from the rod weight and the seismic shock factors as given below

$$
P=\frac{N_{R} W_{R}}{N_{G}+0.5} N
$$

where

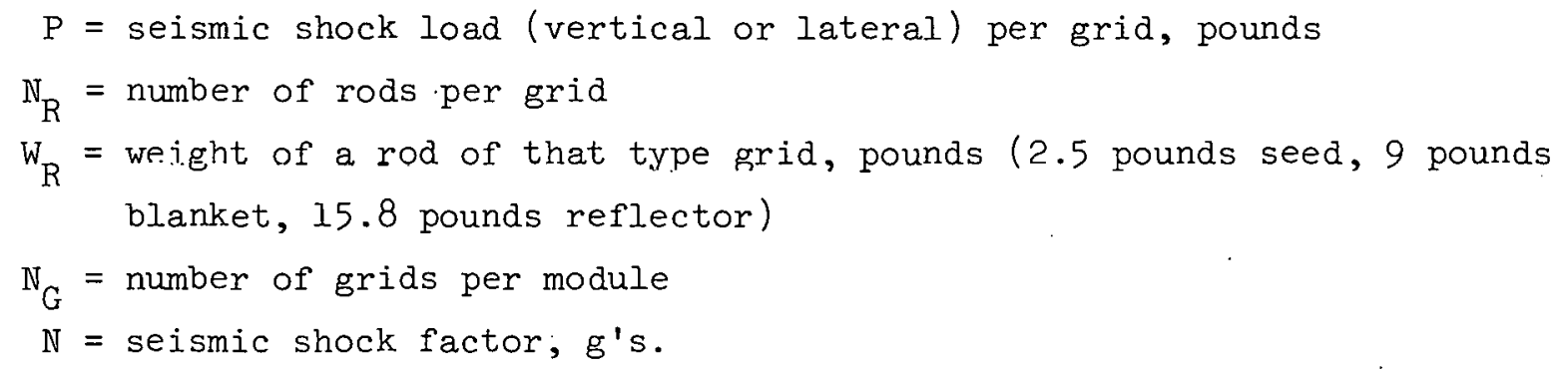

The 0.5. factor in the divisor accounts for the fact that the rods are attached to only one base plate. The seismic shock factors and resulting vertical and lateral loads are listed in Table B-l for each grid type. These loads were considered to be uniformly distributed in each cell in the appropriate direction to determine the seismic shock stresses.

The stresses derived from these accident and upset loading conditions were individually added to the primary stresses and compared against the primary stress limits. The stresses associated with the cyclic scram and seismic shock conditions were determined to be sufficiently low, such that consideration of these cyclic stresses resulted in negligible fatigue usage.

\section{Shipping Loads}

Grid components were subjected to both static loads due to fuel rod weight and dynamic acceleration loads due to transport shock during shipinent of the modules. Stresses imposed on the grid components from the maximum static load 
condition were calculated. The margin available for dynamic loads was then determined by subtracting these stresses from the room temperature yield strength of the AM-350 grid material (125,000 psi). These limits thereby assured that the grid components did not experience local yielding during shipping.

Two important findings were obtained from the shipping analysis. First, the internal boundary components of the blanket grid were found to be overstressed (beyond the yield strength limit) during shipping. These components were redesigned to eliminate this condition. Two curls near the internal corners, which limited grid deflection and thereby raised the stress levels in these components, were eliminated. The second finding was that shipping the reflector grids in a horizontal position resulted in statis l, na.ds which nearly exceeded the room temperature yield strength limit of the AM-350 grid material. 'l'heref'ore, the ref'lector modules, having relatively heavy fuel rods and few grid supports, were shipped in a vertical position.

\section{REFERENCE}

1. R. M. Clark, "MDSFP - A Computer Program for Elastic Solution of ThreeDimensional Structures by the Finite Element Method," WAPD-TM-1187, February 1979. 
TABLE B-1. SEISMIC SHOCK LOADS PER GRID

\begin{tabular}{|c|c|c|c|c|c|c|c|}
\hline \multirow{2}{*}{$\begin{array}{l}\text { Grid } \\
\text { Type }\end{array}$} & \multirow{2}{*}{$\begin{array}{l}\text { Number } \\
\text { Rods per } \\
\text { Grid }\end{array}$} & \multirow{2}{*}{$\begin{array}{c}\text { Rod } \\
\text { Weight } \\
\text { Ib }\end{array}$} & \multirow{2}{*}{$\begin{array}{l}\text { Number } \\
\text { Grids } \\
\text { per } \\
\text { Module }\end{array}$} & \multicolumn{2}{|c|}{$\begin{array}{l}\text { Seismic Shock } \\
\text { Factor, g's }\end{array}$} & \multicolumn{2}{|c|}{$\begin{array}{l}\text { Seismic Shock } \\
\text { Loads per Grid, It }\end{array}$} \\
\hline & & & & Vertical & Lateral & Vertical & Lateral \\
\hline Seed & 619 & 2.5 & 9 & 0.33 & 0.37 & 54 & 60 \\
\hline \multicolumn{8}{|l|}{ Blanket } \\
\hline I & 444 & 9.0 & 8. & 0.10 & 0.37 & 47 & 174 \\
\hline II & 564 & 9.0 & 8 & 0.10 & 0.37 & 60 & 221 \\
\hline III & 633 & 9.0 & 8 & 0.10 & 0.37 & 67 & 248 \\
\hline \multicolumn{8}{|c|}{ Reflector } \\
\hline IV & 228 & 15.8 & 6 & 0.05 & 0.28 & 28 & 155 \\
\hline V & 166 & 15.8 & 6 & 0.05 & 0.28 & 20 & 113 \\
\hline
\end{tabular}




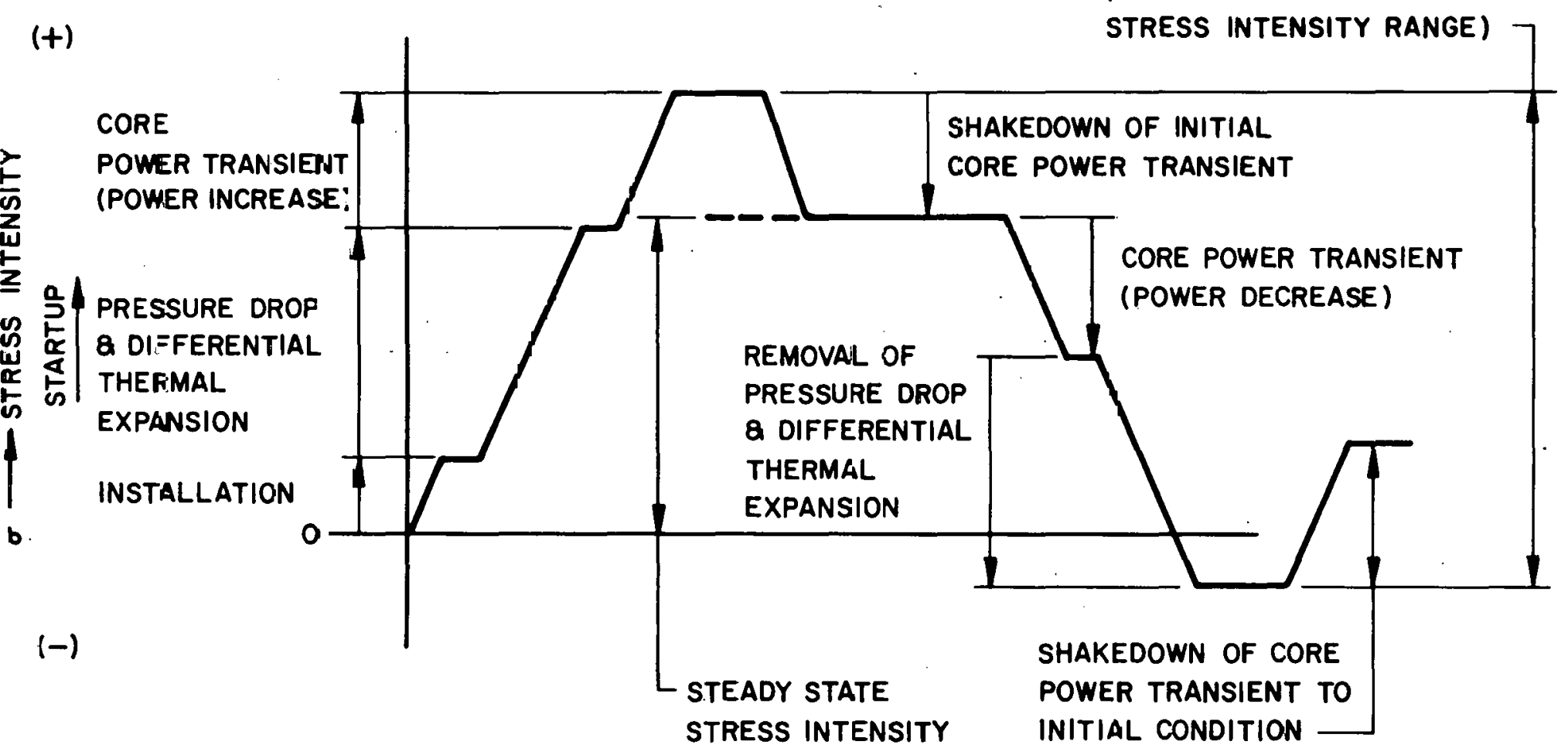

Figure B-I. Contributions to Grid Siress Cycle 


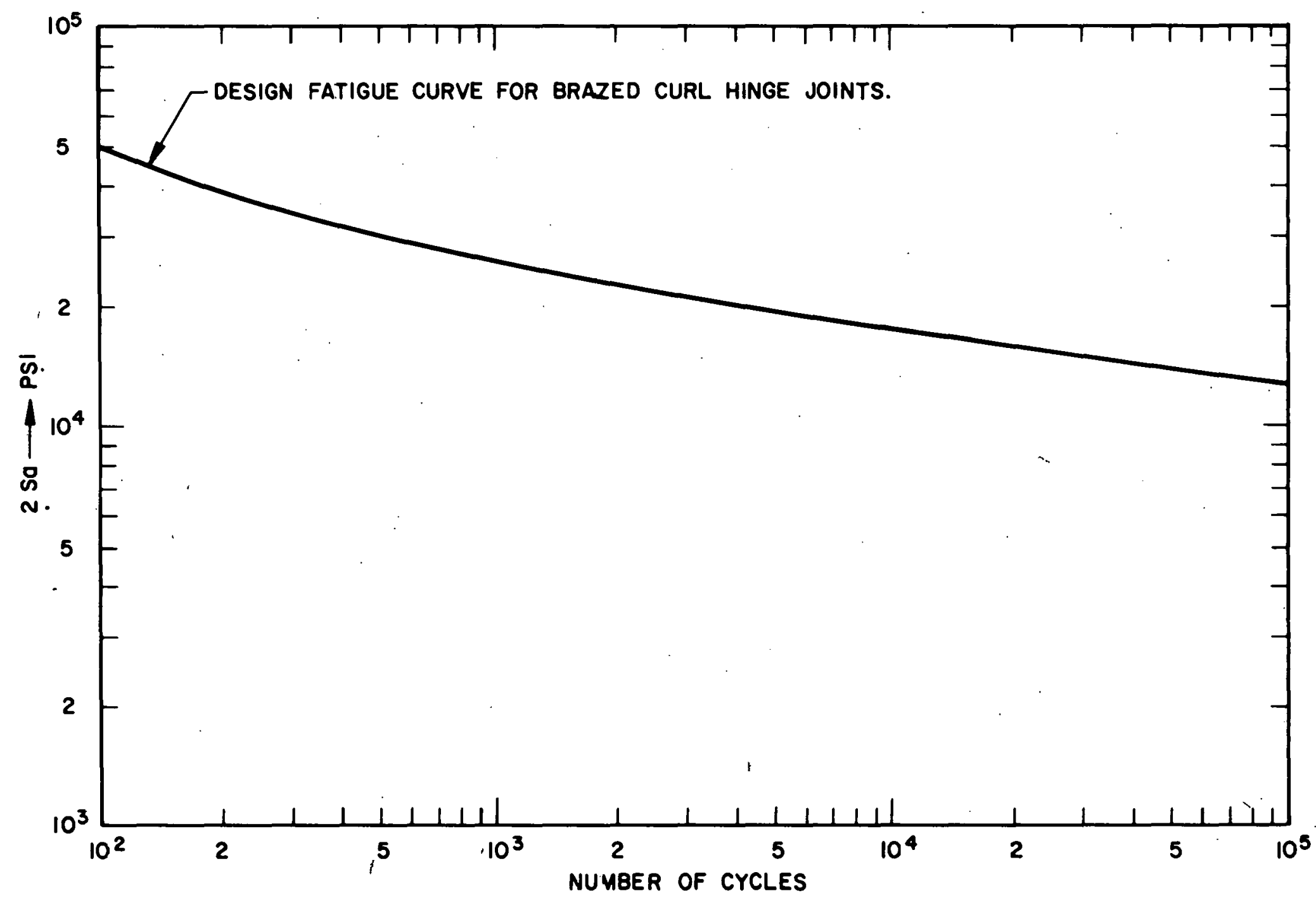


The rod lattice of the LWBR core can be characterized as "tight," that is, rod-to-rod clearances are very small to enhance breeding properties. The standardblanket region, one of high breeding gain, is especially tight. The nominal rod-to-rod clearance in this region is only 0.058 inch, compared to about 0.122 inch for typical commercial reactors. At the grid levels, the nominal radial clearance between a standard blanket fuel rod and the grid panels is only 0.022 inch. Clearances between fuel rods and grid panels in other regions of the core are similarly tight, being 0.025 inch in the seed and reflector regions and 0.044 inch in the power-flattening blanket region.

Rod-to-grid contact is undesirable for several reasons:

1. Rod cladding temperatures are increased in the contact area. While thermal-hydraulic studies have shown that maximum cladding temperatures resulting from rod-to-grid panel contact do not lead to excessive corrosion, the cladding temperatures are increased over non-contact conditions and approach the thermal limits imposed to prevent cladding degradation.

2. Fuel rod cladding wear may be induced at the rod-panel contact point, with the wear depth increasing in a manner similar to rod contact at grid dimples and springs, but in a less controlled configuration.

3. Rod contact at assembly may cause the rod to jam in that cell during rod pulling, causing an increased number and depth of scratches and possible grid damage.

Further, the thicker sections of the machined connectors, particularly in the blanket grids, were recognized as areas where rod-to-grid contact was even more undesirable. Therefore, clearances had to be controlled to a greater extent. The thicker connector panels that are attached to support posts do not provide the same cooling capability as sheet metal components. In these cases, the rod, if in contact with the panel, may receive some cooling by conduction of heat through the panel to the coolant in the adjacent cell. The length of fuel rod in close proximity (less than 0.005 inch clearance) to a blanket grid connector, therefore, was limited to 0.5 inch or less. This requirement was applied to the connector stem and lug, as well as to the connector panel at the grid level. 
Rod-to-grid contact must be controlled independently of rod-to-rod clearance requirements. The latter requirements alone do not prevent the rods from coming into close proximity to one or more of the grid panels which form the walls of the grid cells. The minimum rod-to-rod clearance requirements imposed by thermal-hydraulic considerations are reflected in grid cell-to-cell pitch tolerances and grid cell centerline positional tolerances with respect to their "true position." These requirements, however, do not limit the rod-to-grid panel proximity, since for example, a row of rods may be uniformly translated. toward one panel (for example, the spring panel). For the case of uniform translation, the cell-to-cell pitch dimensional requirement could be satisfied. If the translation is less than 0.015 inch, the "true position" requirement will also be acceptable. The clearance to the spring panel, however, is reduced by the amount of the translation, and possibly more by any panel distortion in this spring panel. Other factors may also cause reduction in the rod-to-grid panel clearances, such as fuel rod bow, cladding ovality, cladding wear, diametral shrinkage, grid assembly tilt, and grid corrosion. If these clearance reductions are sufficient.ly 7.arge, the fuel rod may contact the grid jallel uver some portion of. the panel's length.

It is desirable, therefore, to keep the fuel rods centered in the cell. Minimum initial rod-to-grid panel clearance requirements were specified for each panel in each cell. The requirement.s varied for eash panel nf a grid type because of the different contributions to reduction in clearance. As an example of the nature and magnitude of these clearance reductions in LiWRR grids, Table C-1 presents values of the clearance reduction parameters which are considered to occur under the worst case conditions in the blanket grids. Note that the worst time in life is at Beginning-of-Life (BOL) for panels 1, 2, and 6, but is at End-of-Life (EOL) for panels 3, 4, and 5 (see Figure C-1 for identification of grid panels). This is the result of fuel rod cladding shrinkage and wear, which causes the rod to move away from panels 1,2 , and 6 and toward panels 3,4 , and 5 by the action of the spring force. It is also ncted that at BOL the externally pressurized rod may become oval as the cladding deforms onto the fuel pellet. While rod ovality does not affect the clearance 
to panels 1,3 , and 5 because of the 120 degree dimple orientation, the clearance to panels 2, 4, and 6 is reduced. At EOL the cladding has deformed completely onto the fuel pellet such that the rod is no longer oval, but is a smaller diameter round rod: A clearance reduction allowance for rod ovality is therefore included for panels 2 and 6 , as the worst time in life occurs at BOL; it is not included for panel 4 with a worst case condition at EOL.

With a nominal diameter fuel rod located in the center of a standard blanket cell, a 0.022-inch clearance exists between the rod and the grid panels. From the worst case clearance reductions listed in Table C-2, it is observed that panels.2, 3, 4, 5, and 6 of standard blanket cells do not have sufficient clearance to meet these worst case conditions. In fact, Panel 1 has only $0.0045-i n c h$ clearance to allow for manufacturing process variations in cell centerlines and panel straightness. Design requirements for rod-to-grid clearances were therefore established at values less than the worst case reduction to allow for manufacturing tolerances, but which also provided an acceptably small statistical probability of rod-to-grid contact. These design proximity clearance requirements for the as-manufactured grids are shown in Table C-3.

The number of rod-to-grid contacts expected to occur during core lifetime is included in Table $\mathrm{C}-3$. These numbers were based on a combination of measured initial rod-to-grid clearances (measured after fabrication of the grids) and the statistical probability of contact for these clearances, considering the rodto-grid clearance reductions for each panel (such as those listed in Table C-l for blanket grids). Only one contact in three cores was predicted for seed grids because of the relatively small reductions in rod-to-grid panel clearances during core lifetime. Approximately four contacts per core were predicted to occur in the blanket grids, all in the larger diameter ( 0.572 inch) standard blanket rod region. The smaller diameter ( 0.527 inch) power-flattening rods have greater clearances and are approximately one thousand times less likely to make contact with a grid panel. Of these four contacts, some are predicted to occur at beginning of core life and some at end of life. Some will also occur in the rod regions containing only thoria, for which the rod cladding temperatures are lower than for regions containing the binary fue 1 . 
In the event that a rod does touch a panel, a fuel rod cladding temperature assessment for rods touching or in close proximity to (less than about 0.001 inch) grid panels indicated that the cladding temperatures would be acceptable and that the cladding would not be degraded due to excessive corrosion. There are 26 predicted rod-to-grid contacts in the reflector grids. Since the reflector rods operate in low power (low heat flux) regions, however, the cladding surface temperature resulting from contact is much less than these thermal limits. 
Cause of Clearance Reduction

A. Fuel Rod Considerations

1. Clad Eccentricity

2. Fuel Rod Diameter

a. Minimum Diameter

b. Maximum Diameter

c. BOL rod pressurization

and thermal expansion

3. Shrinkage, Diametral
a. Body
b. Groove
c. Ovality
d. Void shrinkage

4. Fuel Pellet Chipping

5. Cladding Wear

Total Fuel Rod

B. Grid-Rod Alignment

1. Fuel rod bow

2. Grid-to-grid offset

3. Grid tab slippage

4. Grid assembly tilt

5. Thermal bow

Total Alignment

C. Other Considerations

1. Panel deflection

2. Cell expansion

3. Grid corrosion

4. Dimple deflection correction

5. Support post standoti

6. Inspection probe correction

for smaller diameter

Total Other: Considerations

Tota'l Clearance Reduction $(A+B+C)$
Panel 1

(Spring Panel)

Worst Case: BOL

Sta.

PFB
Panel 2 \& 6

Worst Case: BOI. Std. PFB
0.0
0.0
0.5
0.5

0.0

0.0

0.0

0.0

2.3

3.8

1.5

2.5

0.6

0.6

0.0

0.0

0.0

0.0

0.0

0.0

0.0

0.0

2.9

0.9

1.2

1.0

5.9

0.2

9.2

0.0

$-0.8$

0.0

2.0

2.4

.. .8

5.4

17.5
0.0

0.0

0.0

0.0

0.0

$\frac{0.0}{4.4}$

1. 3

1. 3

1. 0

5.9

0.2

9.7

0.0

$-0.8$

0.0

2.0

2. 4

1.8

5.4

19.5
0.0

0.0

5.0

0.0

0.0

$\frac{0.0}{7.0}$

7.0

0.9

1.2

5.5

5.9

0.4

13.9

1.0

$-0.8$

0.0

1.0

2.11

1. 8

5.4

26.3
0.0

0.0

5.0

0.0

0.0

0.0

8.0

1. 3

1.3

5.5

5.9

0.4

14.4

1.0

$-0.8$

0.0

1.0

2.4

1.8

5.4

27.8

All clearances are given in mi.s ( 0.001 inch)

EOL = End-of-Life

BOL $=$ Beginning $\rightarrow$ f - Li, fe

Std $=$ Standard Blanket $\mathrm{Cell}$

$\mathrm{PFB}=$ Power-rlattening Blanket $\mathrm{Cell}$ 
Panel $3 \& 5$ (Dimple Panels) Worst Case: EOL Std. $\mathrm{PFB}$
Panel 4

Worst Case: EOL Std. PFB
0.0
0.0
0.5
0.5

2. Fuel Rod Diameter

a. Minimum diameter

b. Maximum diameter

c. BOL rod pressurization and thermal expansion

$\begin{array}{rrrr}0.0 & 0.0 & 0.8 & 0.8 \\ 0.0 & 0.0 & 0.0 & 0.0 \\ 0.0 & 0.0 & -0.2 & -0.2\end{array}$

3. Shrinkage, Diametral.
a. Borly
b. Groove
c. Ovality
d. Void shrinkage

0.0

1.5

0.0

0.0

3.0

0.5

0.0

0.5

0.5

0.5

2.8

2.8

Total Fuel Rod

5.3

6.8

3.2

3.2

3.0

6.0

0.0

0.0

0.5

0.5

4. Fuel Fellet ('nupping

0.5

0.5

5. Cladding Wear

B. Grid-Rod Alignment

1. Fuel rod bow

1.8

3.2

2.5

2. Grid-to-grid offset

3. Grid tab slippage

5.5

3.8

5.5

5.9

5.9

0.4

$-0.4$

7.6 .1

18.8

4.6

4.6

12.9

.15 .9

5. Thermal bow

Total Alignment

C. Other Considerations

1. Pancl deflection

2. Cell expansion

n.

0.0

ก.

0.0

0.5

0.5

1.9

1.5

2.4

2.4

1.8

3.2

2.5

3.8

1.0

1.0

5.9

5.9

0.2

0.4

11.4

14.3

4. Dimple deflection correction

5. Support post standoff

6. Correction for smaller diameter inspection probe

Total Other

0.0

0.0

2.0

2.0

ก. 8

$-0.8$

1.0

1.0

1.0

0.4

2.4

2.4

]. 8

1.8

4.8

4.4

7.4

6.8

26.2

30.0

31.7

37.0

A.ll clearances are given in mils ( 0.001 inch)

EOL $=$ End-of-Life

BOL = Beginning-of-Life

Std $=$ Standard Blanket Cell

$\mathrm{PFB}=$ Puwer-flattening BLanket Cell 
TABLE C-2. COMPARISON OF NOMINAL AVAILABLE CLEARANCES AND REDUCTIONS UNDER WORST CASE CONDITIONS

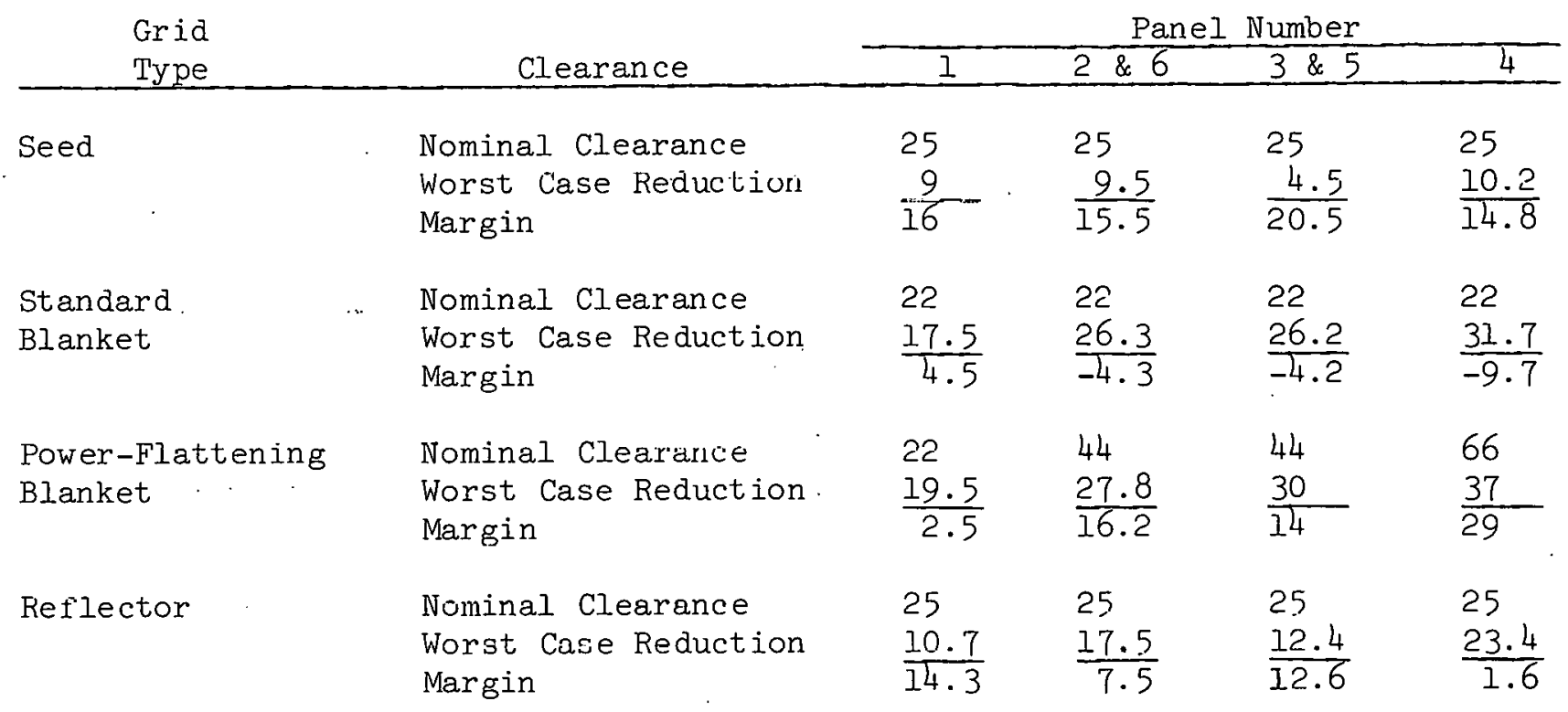

All clearances are given in mils ( 0.001 inch). 
TABLE C-3. COMPARISON OF DESIGN PROXIMITY REQUIREMENTS AND WORST CASE CLEARANCE REDUCTIONS

\begin{tabular}{|c|c|c|c|c|c|c|}
\hline $\begin{array}{l}\text { Grid } \\
\text { Type }\end{array}$ & Clearance & $\begin{array}{c}\text { Panel } \\
1 \\
\end{array}$ & $\begin{array}{l}\text { Panel } \\
2 \& 6 \\
\end{array}$ & $\begin{array}{l}\text { Panel } \\
3 \& 5 \\
\end{array}$ & $\begin{array}{c}\text { Panel } \\
4\end{array}$ & $\begin{array}{l}\text { Statis. } \\
\text { Number } \\
\text { Contacts } \\
\text { Per Core } \\
\end{array}$ \\
\hline Seed & $\begin{array}{l}\text { Design Proximity } \\
\text { Worst Case Reduction } \\
\text { Margin }\end{array}$ & $\begin{array}{r}14 \\
9 \\
5.1\end{array}$ & $\begin{array}{r}10.5 \\
9.5 \\
1.0\end{array}$ & $\begin{array}{r}10.5 \\
4.5 \\
6.0\end{array}$ & $\begin{array}{l}13 \\
\frac{10.2}{2.8}\end{array}$ & 0.33 \\
\hline $\begin{array}{l}\text { Standard } \\
\text { Blanket }\end{array}$ & $\begin{array}{l}\text { Design Proximity } \\
\text { Worst Case Reduction } \\
\text { Margin }\end{array}$ & $\begin{array}{r}9.3 \\
17.5 \\
-8.2\end{array}$ & $\frac{11}{26 \cdot 3}$ & $\begin{array}{l}11 \\
\frac{26.2}{-15.2}\end{array}$ & $\begin{array}{l}17 \\
31 \cdot 7 \\
-14 \cdot 7\end{array}$ & 4.1 .6 \\
\hline $\begin{array}{l}\text { Power -Flattening } \\
\text { Blanket }\end{array}$ & $\begin{array}{l}\text { Design Proximity } \\
\text { Worst Case Reduction } \\
\text { Margin }\end{array}$ & $\begin{array}{l}13.6 \\
\frac{19}{-5.5}\end{array}$ & $\begin{array}{l}25 \\
27.8 \\
-2.8\end{array}$ & $\begin{array}{l}25 \\
30 \\
-5\end{array}$ & $\begin{array}{l}45 \\
37 \\
8\end{array}$ & 0 \\
\hline Reflector & $\begin{array}{l}\text { Design Proximity } \\
\text { Worst Case Reduction } \\
\text { Margin }\end{array}$ & $\begin{array}{l}11 \\
\frac{10.7}{0.3}\end{array}$ & $\begin{array}{l}12 \\
\frac{17.5}{-5.5}\end{array}$ & $\begin{array}{l}12 \\
\frac{12.4}{-0.4}\end{array}$ & $\begin{array}{l}19 \\
\frac{23.4}{-4.4}\end{array}$ & 26 \\
\hline
\end{tabular}

All clearances are given in mils ( 0.001 inch). 


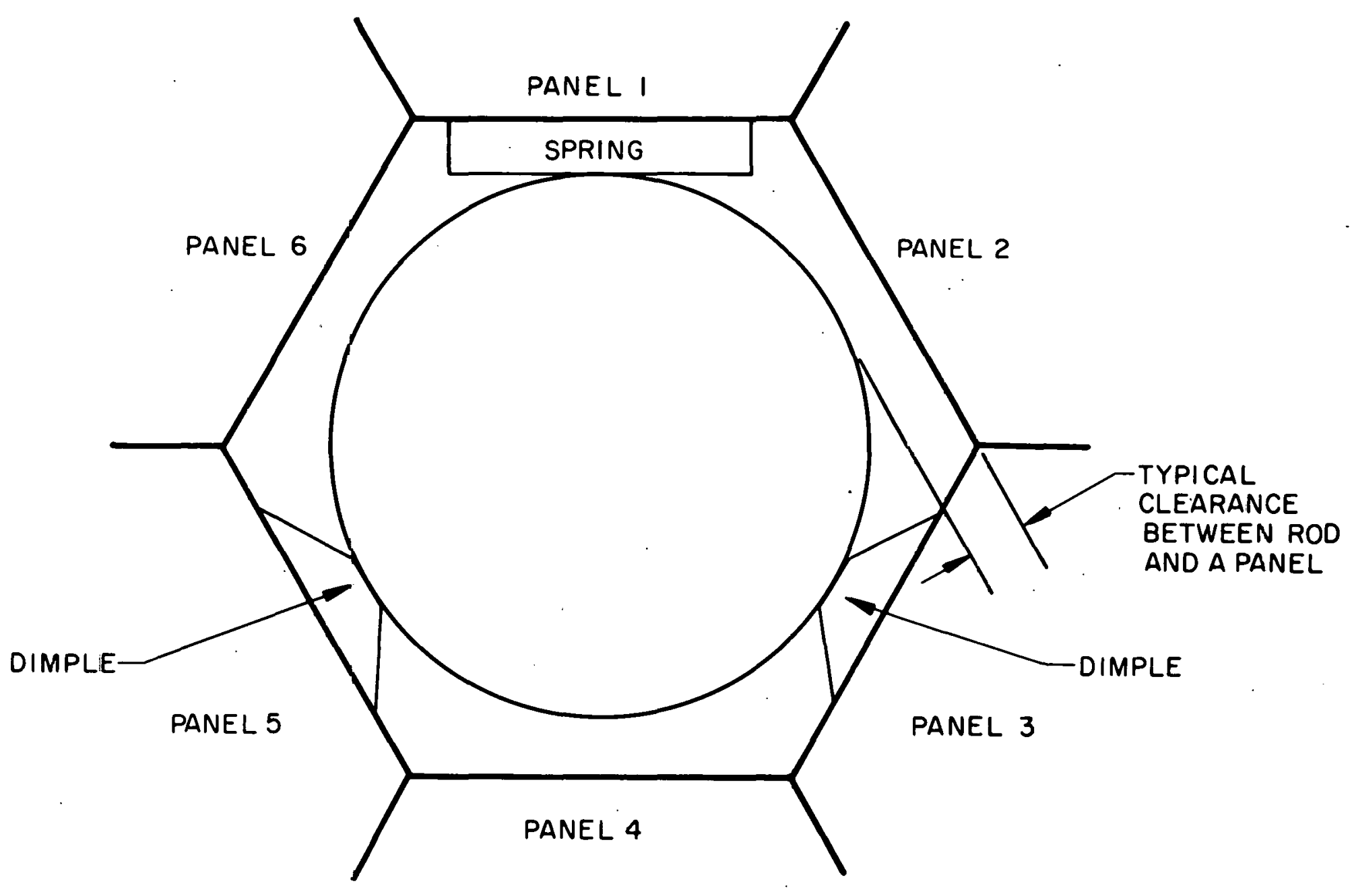

Figure C-I. Identification of Grid Panel Numberirg Scheme 


\section{A. Mechanical Properties}

Very thin grid material (approximately 0.014 to 0.018 inch thick) was needed to minimize neutron parasitic loss. This thin material had to have a tensile strength at design operating temperatures on the order of 100,000 psi to carry the grid loads, and a yield strength sufficiently high to preclude. plastic strain under the grid loads. Also, since cyclic loading conditions were imposed during transient core operation, the material had to demonstrate adequate fatigue life under the stress levels and number of cycles encountered. A summary of the mechanical properties of the AM-350 grid material is presented in Figures D-1 through $\mathrm{D}-7$.

Tensile properties of AM-350 sheet, wire, and bar material are shown in Figures D-1, D-2, and D-3, respectively. The yield and ultimate strengths of the AM-350 sheet and the shear strength of the AM-350 wire are shown as functions of carbon content. The carbon level was reduced from that of the material received from the supplier through a decarburization thermal treatment (Reference 1) to enhance the corrosion resistance. AM-350 bar material was obtained with lower initial carbon content because the thicker sections were not readily reduced in carbon content during the decarburization operation.

The stress versus strain relationships for AM-350 sheet material having two different carbon and nitrogen contents, representing the approximate lower and nominal levels encountered in the LWBR grids, are illustrated in Figures D-4 and D-5. During irradiation, the tensile strengths increase (Figures D- 6 and $\mathrm{D}-7$ ), but satisfactory ductility is retained. Tests also confirmed that the brazed joint grid design possessed adequate fatigue life (see Appendix E).

AM-350 sheet, bar, and wire were capable of consistently meeting the mechanical property limits specificd for design purposes as listed in Table D-I. B. Corrosion Resistance

The material selected for use in the LWBR core as the fuel rod support structure had to meet the following criteria with respect to corrosion resistance:

1. The material must not be susceptible to intergranular or intragranular corrosion. 
2. The material must not be susceptible to stress corrosion cracking, since it is under varying degrees of stress.

3. The material must exhibit a low general corrosion rate in order to carry the loads throughout core life of at least 30,000 hours.

4. The material must be capable of standing in static water for extended periods of time without pitting.

Corrosion resistance of AM-350 was determined to be a function of material chemistry, thermal treatment, reactor coolant chemistry, and the time at temperature and neutron fluence. The general steady-state corrosion rate for AM-350 of the reference chemistry and heat treatment and in the reference coolant chemistry was found to be very low. The depth of oxide penetration in an irradiated environment was determined to average only ahnut. $\cap .13$ mil ovor 30,000 hours at elevated temperatures ( $572 \mathrm{~F}$ ), as illustrated in Figure $n-8$. This materidl is highly resistant to both intergranular and intragranular corrosion, in contrast to AM-350 of non-reference chemistry (higher carbon levels) and non-reference likermal, treatment. The latter alderlal was susceptible, in varying degrees, to these two types of corrosion processes as well as lo pitting corrosion in crevice regions.

Tests also confirmed that the solubility limit of hydrogen in AM-350 having

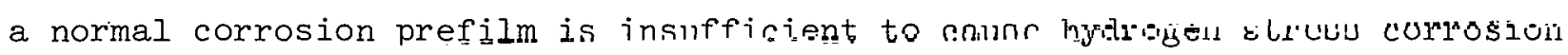
cracking in the operating temperature environment. Further, no evidence of stress corrosion cracking was observed on highly strained AM-350 specimens under room temperature conditions. AM-350 was also resistant to crucking in a potusslum tetraborate solution (PTB), which was being considered as a potential emergency poison solution.

Ir examining irradiation test assemblies containing AM-350 gride, the grid surfaces and edges were observed to be bright and clean in fast neutron flux locations. No crud buildup was reported. In out-of-flux locations the external grid surfaces (boundary surfaces) were observed to have 1 to 2 mils of crud, whlle much less than $i$ mil crud buildup was reported for internal grid component surfaces. 


\section{Stress Relaxation}

The spring force of the LWBR grids was developed by elastically straining the spring. However, certain conditions such as high temperature and neutron flux, change a portion of the elastic strain to plastic strain with consequent reduction in spring force; that is, the spring "relaxes." The spring force must be set high enough initially to account for this loss in spring force. This ensures that the spring retains sufficient elastic strain to meet the spring force requirements at end-of-life.

Stress relaxation was determined to be a function of two basic phienomena which are operative during core life, namely, thermally-induced stress relaxation and radiation-inducer stress relaxation. The first of these, thermally-induced stress relaxation, occurs during the period of hot (530F) core operation prior to initial criticality. In the LWBR core the grids experienced approximately 800 hours under these conditions. Best estimate and upper bounding value correlations for the thermal stress relaxation behavior of AM-350 as a function of time at temperature are shown in Figure D-9. The grids are conservatively assumed to be at $530 \mathrm{~F}$ for the entire period. The stress relaxation was force normalized since the magnitude of the thermal stress relaxation increases with increasing initial spring force. The thermal component of stress relaxation included any thermal instability which may have occurred during this period. Thermal instability is defined as "a non-recoverable cell dimensional change associated with heating to operating temperature and then cooling to room temperature". Investigations of such thermal instability in AM-350, however, revealed no significant non-recoverable changes following a heatup-cooldown cycle.

The radiation-enhanced stress relaxation behavior of AM-350 is shown in Figure D-10. This relationship was obtained from an empirical correlation based on a viscoelastic phenomenological model represented by the following equation:

$$
\frac{R_{i}}{R}=C_{1} e^{-m_{1} \phi t}+\left(1-C_{1}\right) e^{-m_{2} \phi t}
$$

where

$R=$ the radius of curvature of the simple bent beam specimen at some exposure 
$R_{i}=$ the initial radius of curvature

$\phi t=$ fast neutron (greater than $1 \mathrm{Mev}$ ) fluence in units of $10^{20}$ neutrons/ square centimeter

The coefficients $\left(c_{1}, m_{1}, m_{2}\right)$ were determined to be linear functions of carbon and nitrogen content, namely:

$$
\begin{aligned}
& c_{1}=1.01114-3.23124 \mathrm{C}-2.10849 \mathrm{~N} \\
& m_{1}=0.00423+0.065218 \mathrm{C}+0.039212 \mathrm{~N} \\
& m_{2}=0.208876
\end{aligned}
$$

with $\mathrm{C}$ (carbon content) and $\mathrm{N}$ (nitrogen content) in weight percent. It is evident from Figure D-10 that grids having lower carbon and nitrogen contents are desirable, particularly in the higher fluence regions. One of the criteria for placement of the grids at the various grid levels, therefore, was that the grids located in the central, high fluence, grid levels should have an average carbon and nitrogen content as low as permissible; but still consistent with strength requirements.

\section{Effect on Breeding Performance}

AM-350 exhibited a neutron capture cross section among the lowest of any of the non-zirconium materials investigated. For example, calculations were made of the effect of the use of two other materials with the reference grid design on the f'rssile Inventory Katio (the ratio of the f'issile loading at any time to the initial fissile loading). Alloy 718 would have reduced the FIR by 0.0010 , and Hasteloy-N would have reduced the FIR by 0.0014 . If manufactured from either of these two materials, it would be necessary to reduce the grid material thickness to maintain the same FIR as that of AM-350. This would have been incompatible with the tensile strengths of these two materials, however, since both are lower in strength than AM-3.50.

\section{E. Dimensional Stability}

A number of tests have confirmed the dimensional stability of the AM-350 grid material ás well as of the brazed grid design. For example, cell-to-celi pitch measurements of test grids performed before and after irradiation (22,000 hours and $98.9 \times 10^{20} \mathrm{n} / \mathrm{cm}^{2}$ neutron fluence) indicated no significant change (beyond measurement accuracy. of about 0.0034 inch) of the pitch values

D-4 
from their original values. Further, overall grid cell distortion was not observed. The AM-350 test grids exhibited no unstable behavior and did not undergo any dimensional changes which would have required modifications to the components or analysis procedures for predicting grid spring relaxation and follow capability.

\section{F. Wear}

Another criterion for the grid material was the absence of wear to prevent degradation of the structural integrity of the grids and to minimize loss in spring deflection. Since the Zircaloy-4 cladding of the fuel rods was softer than most grid materials being considered, fuel rod wear would normally occur rather than wear of the harder grid material. The hardness of AM-350 in the fully heat-treated condition is $R_{c} 30$ to 42 , as compared with approximately $R_{c}$ 20 for Zircaloy-4 tubing (70 percent cold worked plus stress relief annealed). Hence, wear of the AM-350 grid material was not considered to be a problem.

Examination of grids and test grid sections at rod contact points in numerous tests consistently failed to disclose any measurable wear of the AM-350 grid material. A wide variety of loads, flow conditions, assembly cycles, and reciprocating motion cycles were investigated. The maximum indications of wear: were slight roughening of the spring surface in a few highly loaded blanket grid cells. (Note, however, that improper preparation of the Zircaloy cladding, that is, flash pickling instead of normal pickling of 2 to 3 mils reduction per surface, could cause wear of the grid contact points during rod installation.) These tests revealed that wear of the AM-350 grid material would be negligible and therefore of no concern.

REFERENCES

1. B. R. Gourley, "Decarburization of AM-350 Stainless Steel LWBR Fuel Rod Support Grids:(LWBR Development Program)," WAPD-TM-1131, February 1977. 
TABLE D-1. MECHANICAL PROPERTY DESIGN LIMITS FOR AM-350 MATERIAL USED IN THE LWBR GRIDS

\begin{tabular}{|c|c|c|c|c|c|c|}
\hline Material & Temperature & $\begin{array}{l}\text { Ultimate } \\
\text { Strength } \\
\text { (ksi) } \\
\end{array}$ & $\begin{array}{l}\text { Yield Strength } \\
\text { at } 0.2 \% \text { Offset } \\
(\mathrm{ksi}) \\
\end{array}$ & $\begin{array}{c}\text { Total } \\
\text { Elongation } \\
\text { In '2 Inches } \\
(\%) \\
\end{array}$ & $\begin{array}{l}\text { Shear } \\
\text { Strength } \\
\text { (ksi) }\end{array}$ & $\begin{array}{l}\text { Hardness } \\
\mathrm{R}_{\mathrm{C}}\end{array}$ \\
\hline Sheet & $\begin{array}{l}\text { Room Temp. } \\
600 F\end{array}$ & $\begin{array}{l}135-195 \\
115-165\end{array}$ & $\begin{array}{r}125-170 \\
95-140\end{array}$ & $\begin{array}{l}6-14 \\
3-8\end{array}$ & - & $30-42$ \\
\hline Wire & $\begin{array}{l}\text { Room Temp. } \\
\text { 600F }\end{array}$ & $\begin{array}{l}135-195 \\
115-165\end{array}$ & $\begin{array}{r}125-170 \\
95-140\end{array}$ & $\begin{array}{l}8 \text { min. } \\
4 \text { min. }\end{array}$ & $\begin{array}{r}105-185 \\
80-160\end{array}$ & $30-42$ \\
\hline Bar & $\begin{array}{l}\text { Room Temp. } \\
600 F\end{array}$ & $\begin{array}{l}135-195 \\
115-165\end{array}$ & $\begin{array}{r}100-150 \\
85-140\end{array}$ & $\begin{array}{l}15 \min .(\mathrm{a}) \\
10 \min .\end{array}$ & - & $30-42$ \\
\hline
\end{tabular}

(a) Total elongation is given as the percent in $1 / 2$ inch. 


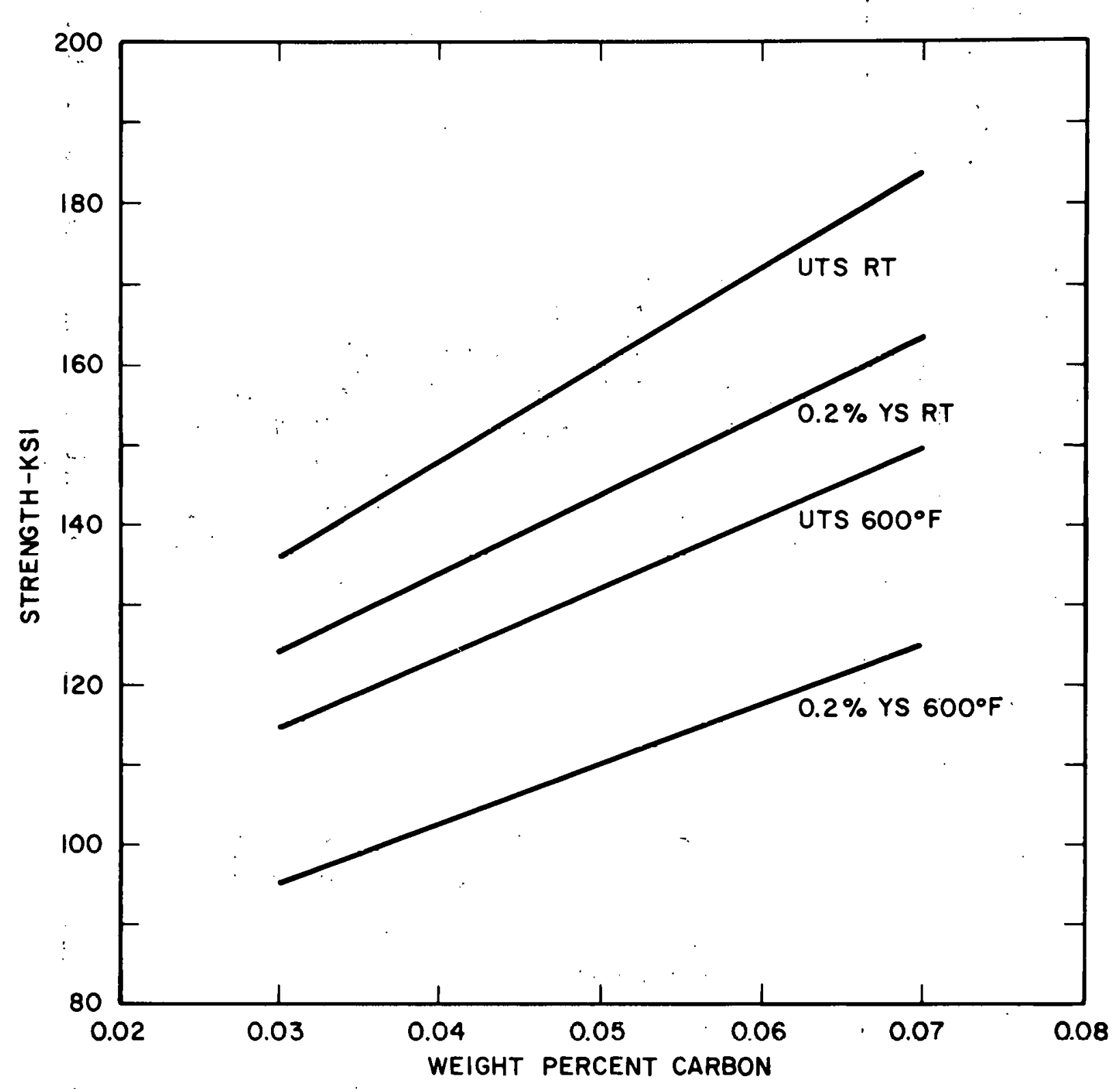

Figure D-1. Room Temperature and 600F Tensile Properties of AM-350 Sheet as a Function of Weight Percent Carbon 


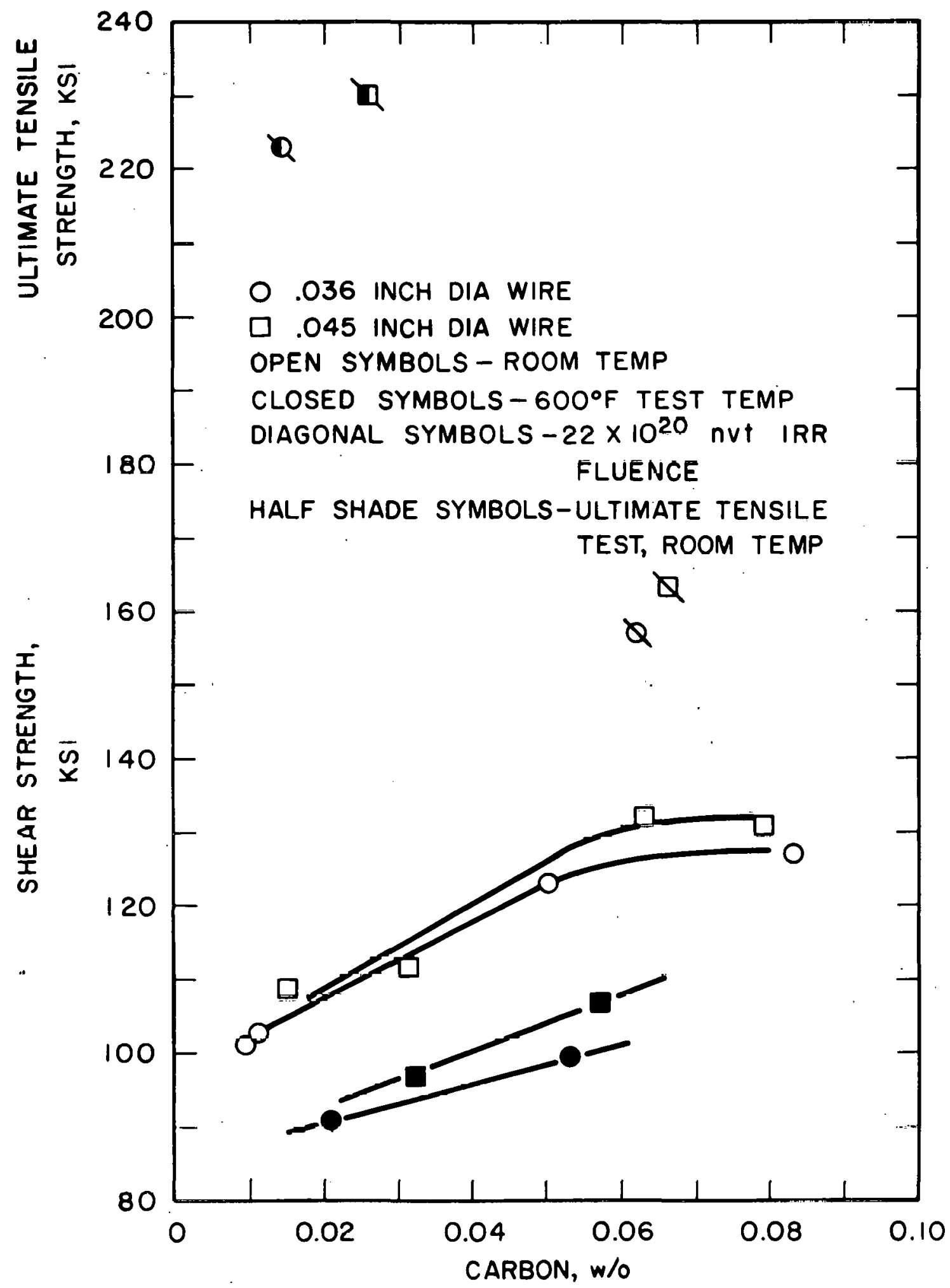

Figure D-2. Irradiated and Nonirradiated Shear Strength of AM-350 Wire 

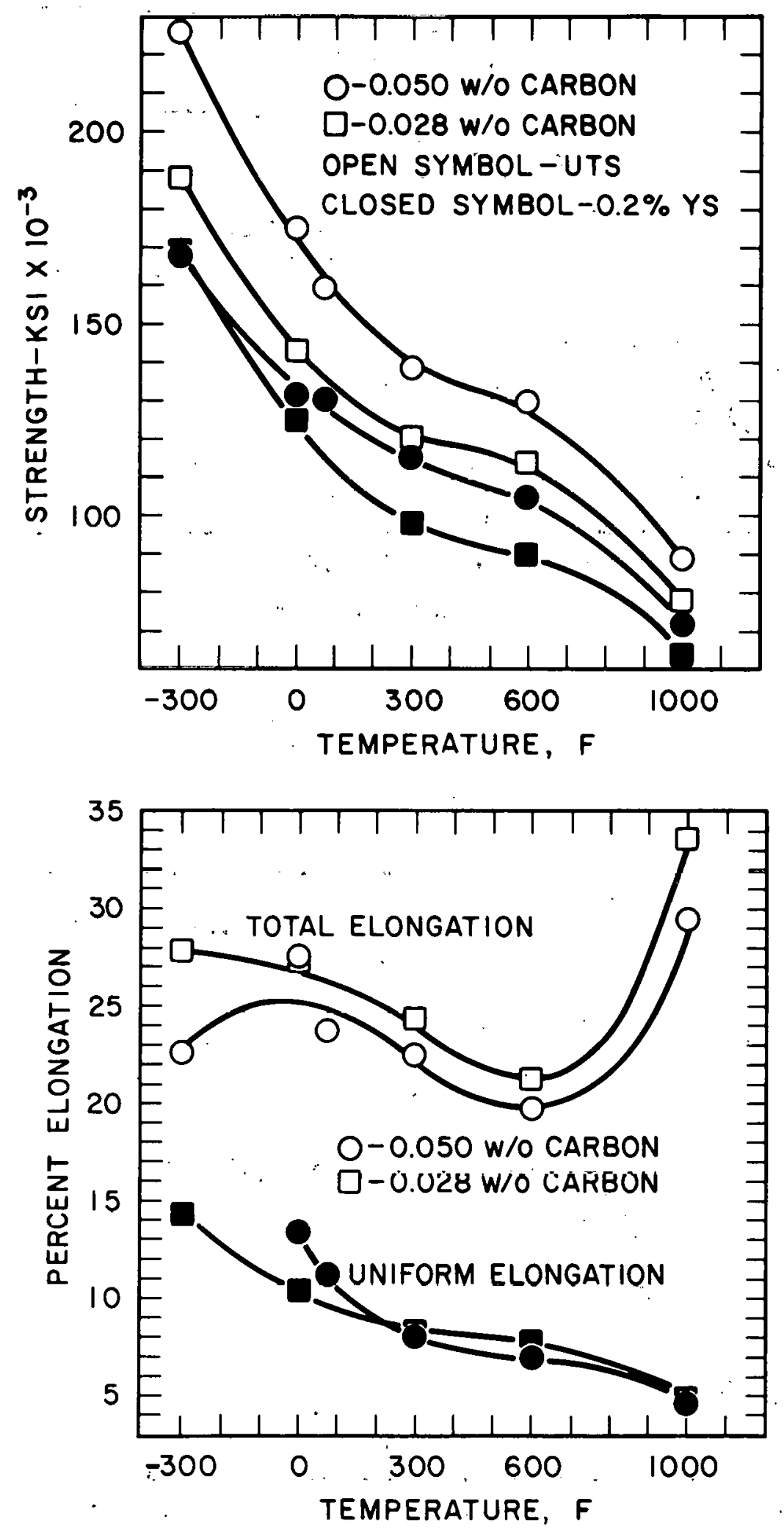

Figure D-3. Tensile and Elongation Properties of Two AM-350 Bar Heats 


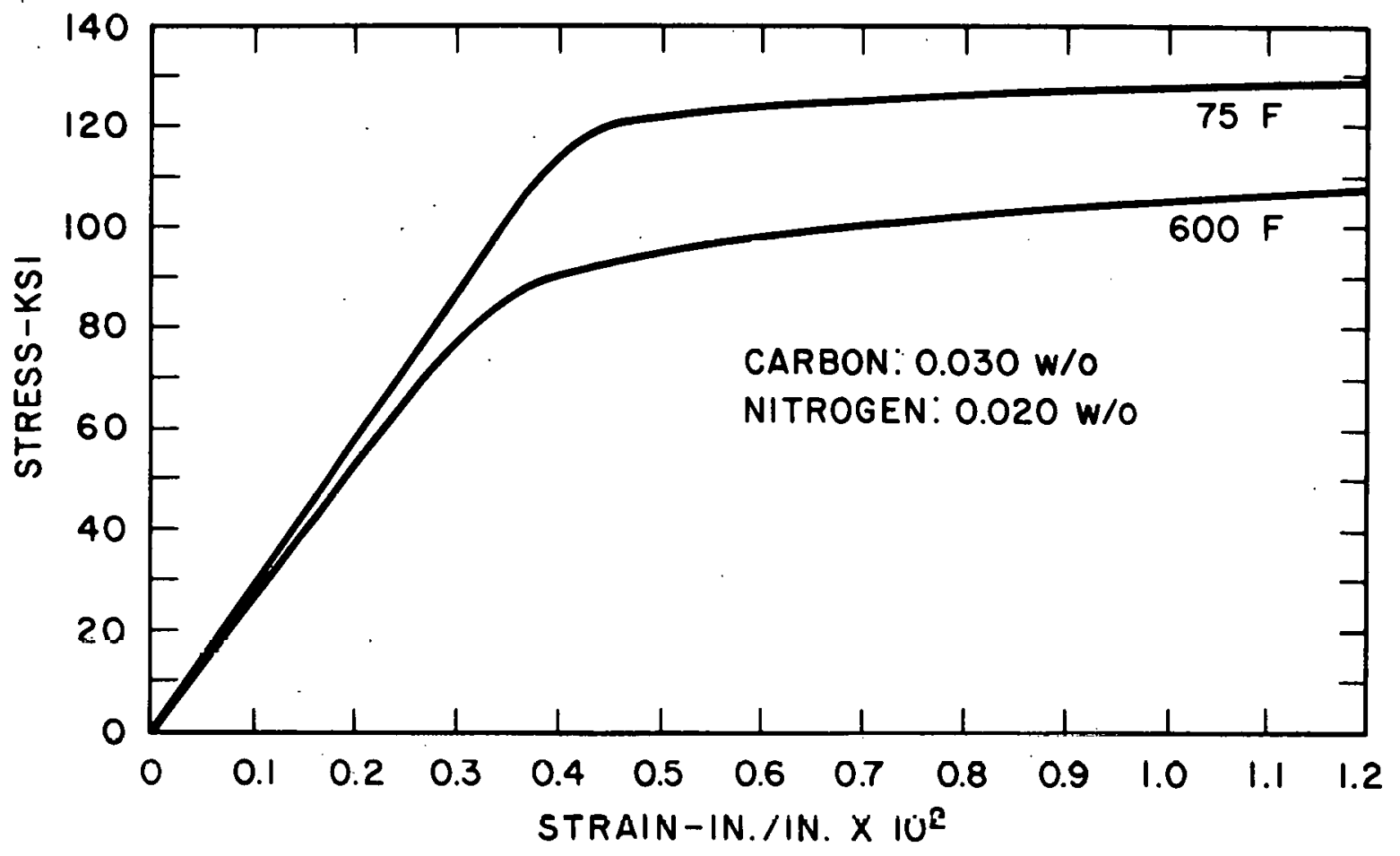

Figure D-4. AM-350 Nonirradiated Sheet Stress Versus Strain, Lower Chemistry

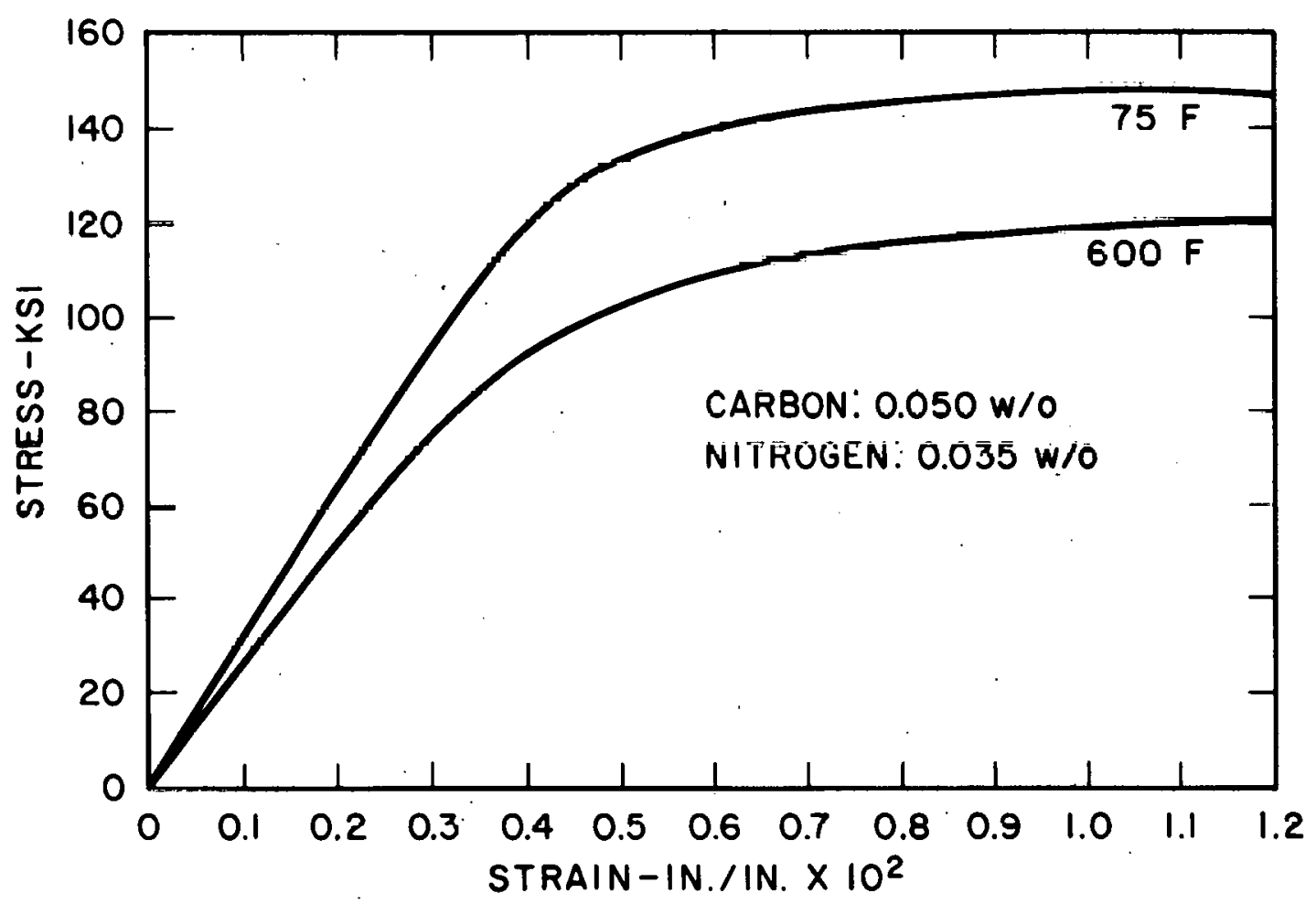

Figure D-5. AM-350 Nonirradiated Sheet Stress Versus Strain, Nominal Chemistry 


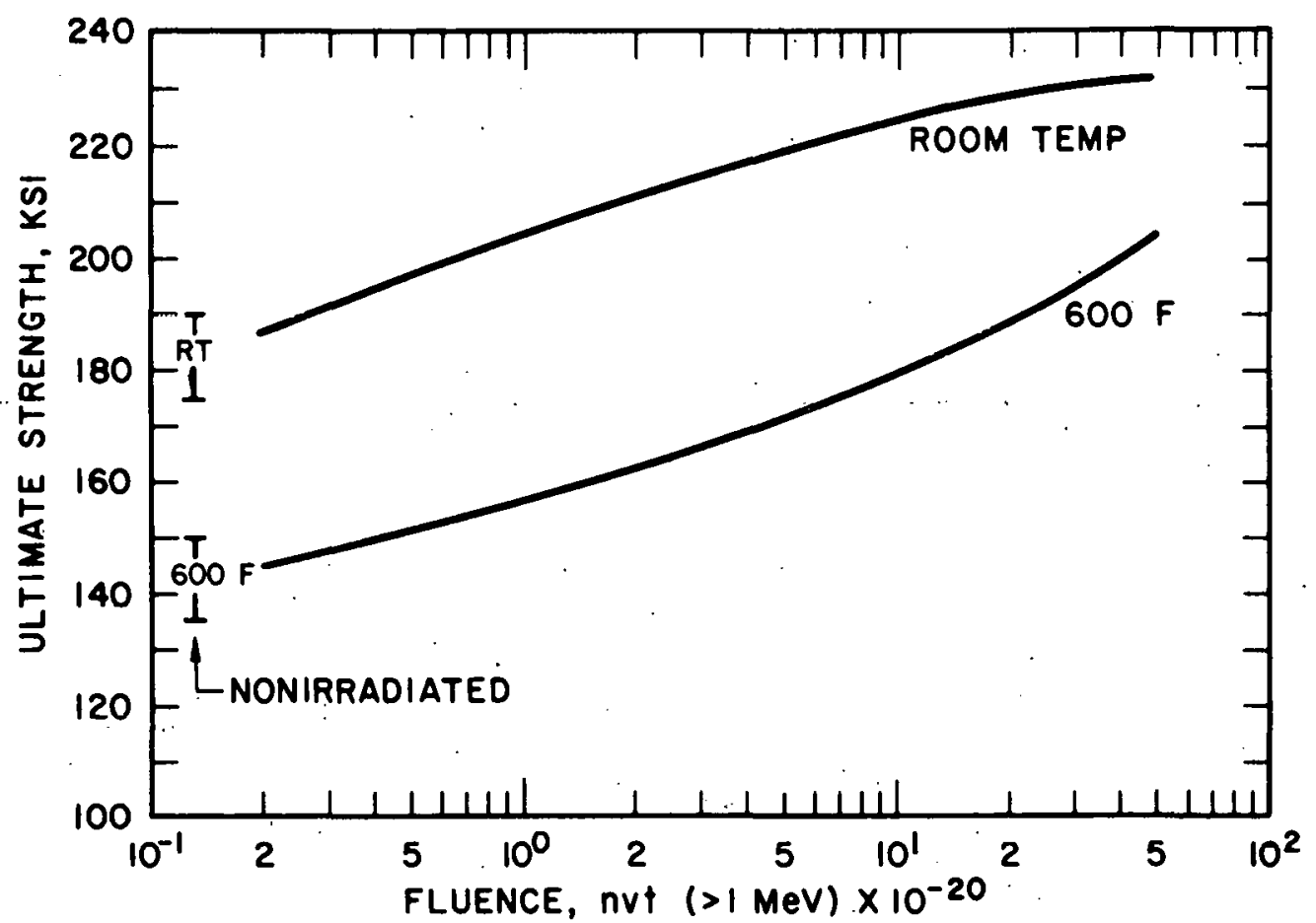

Figure D-6. Ultimate Tensile Strength of AM-350 Sheet as a Function of Neutron Radiation

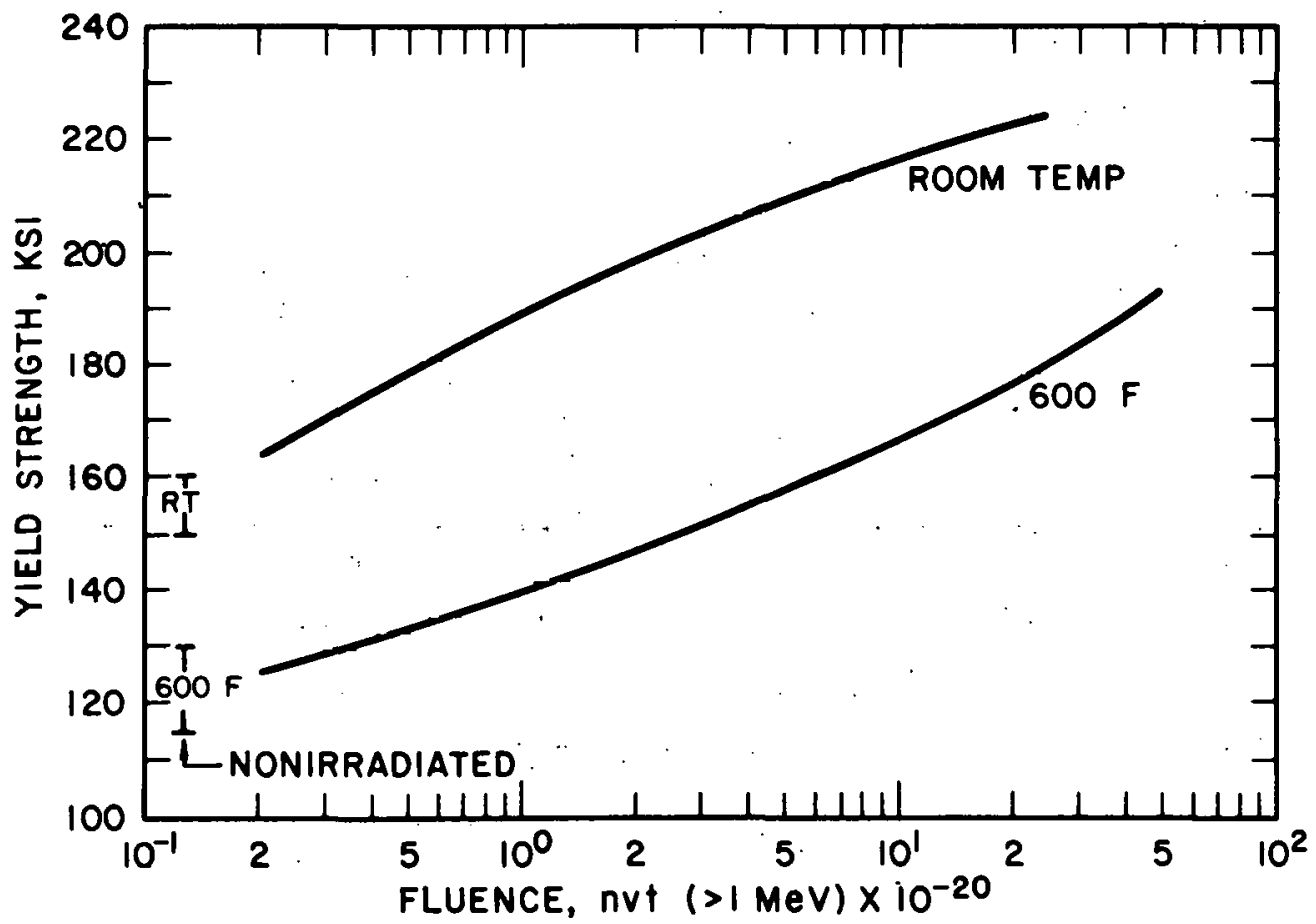

Figure D-7. 0.2 Percent Yield Strength of AM-350 Sheet as a Function of Neutron Radiation 


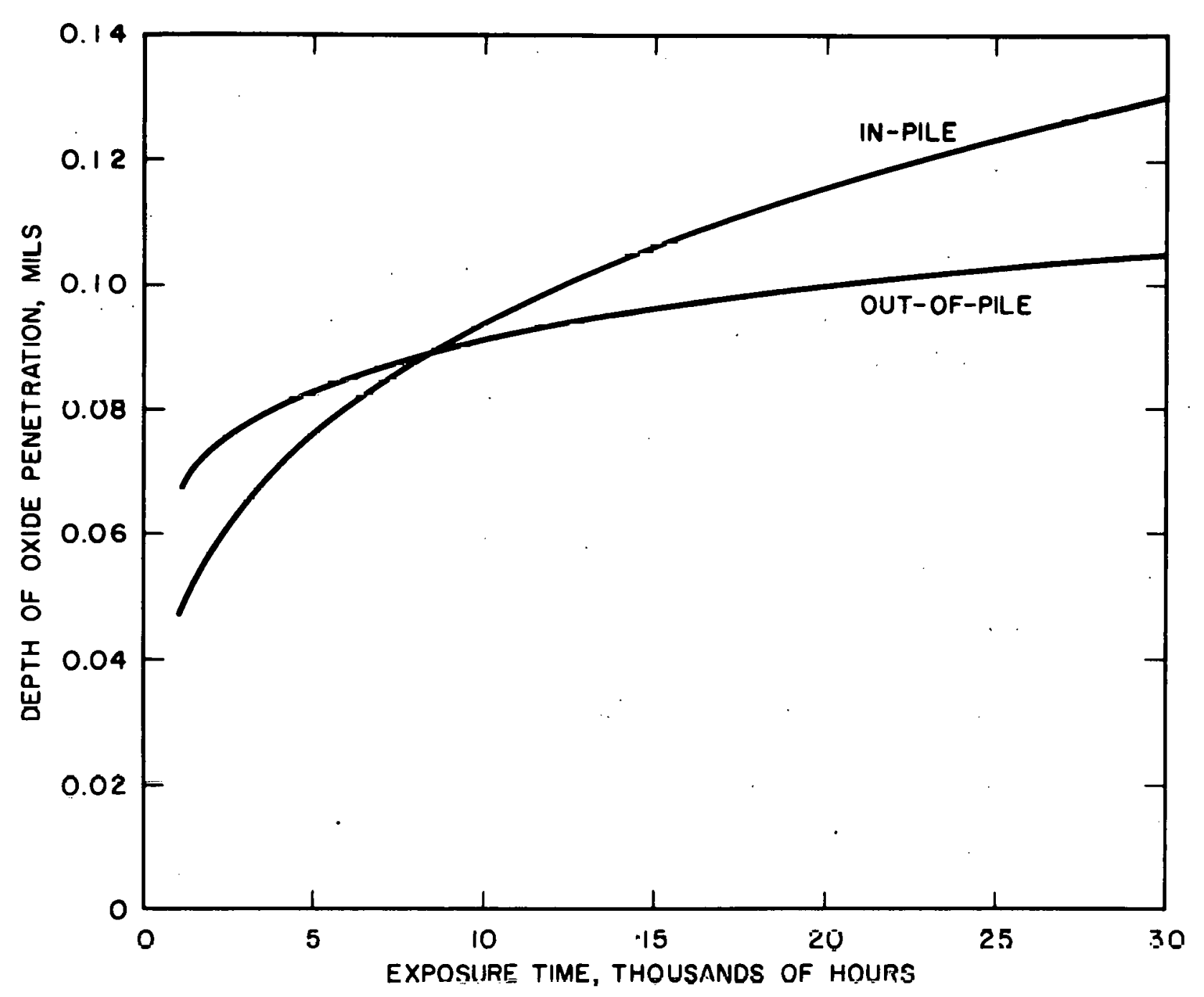

Figure D-8. Corrosion Rates for AM-350 Sheet Material of Reference Heat Treatment and Chemistry 


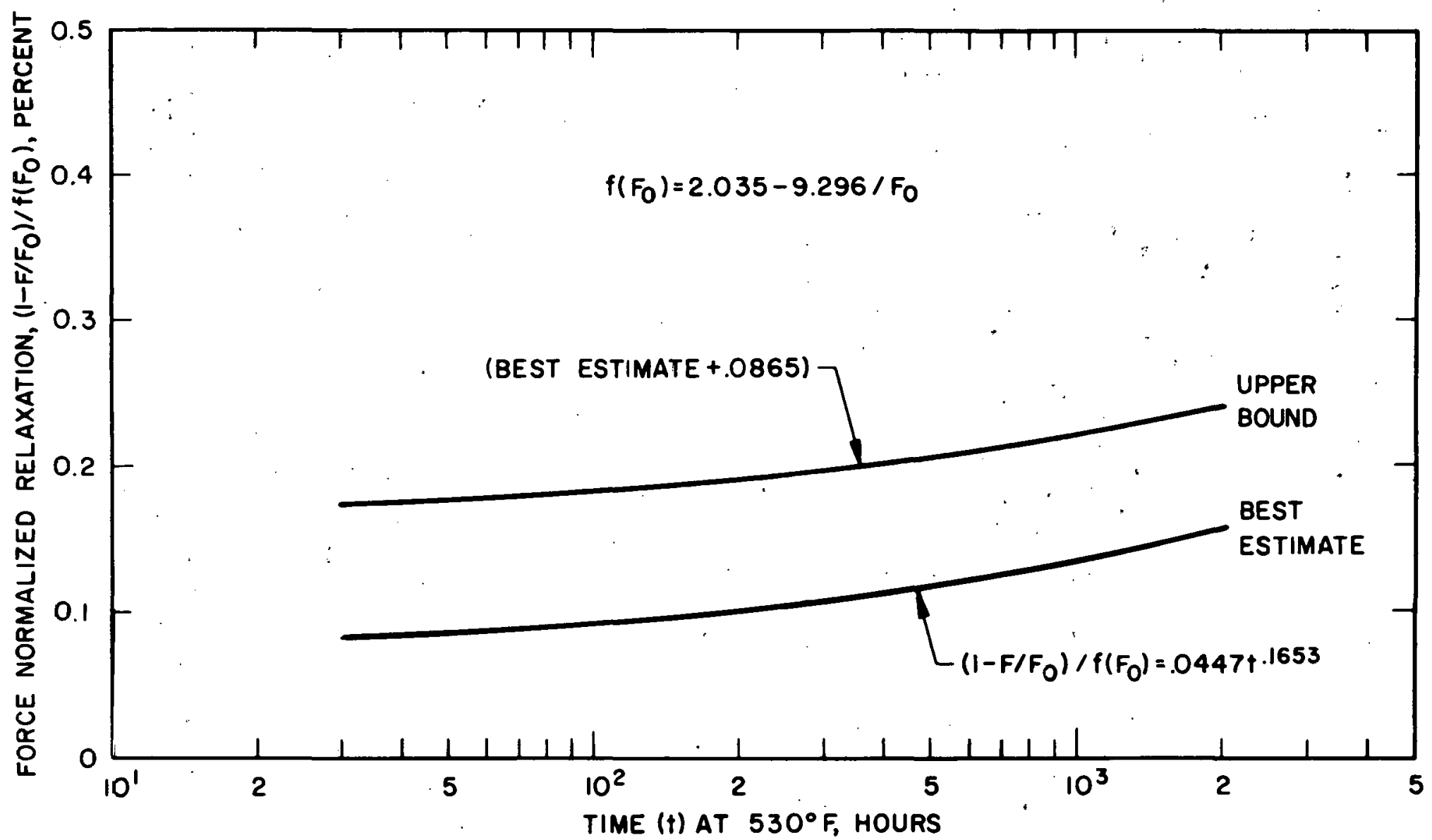

Figure D-9. Thermally-Induced Stress Relaxation of AM-350 


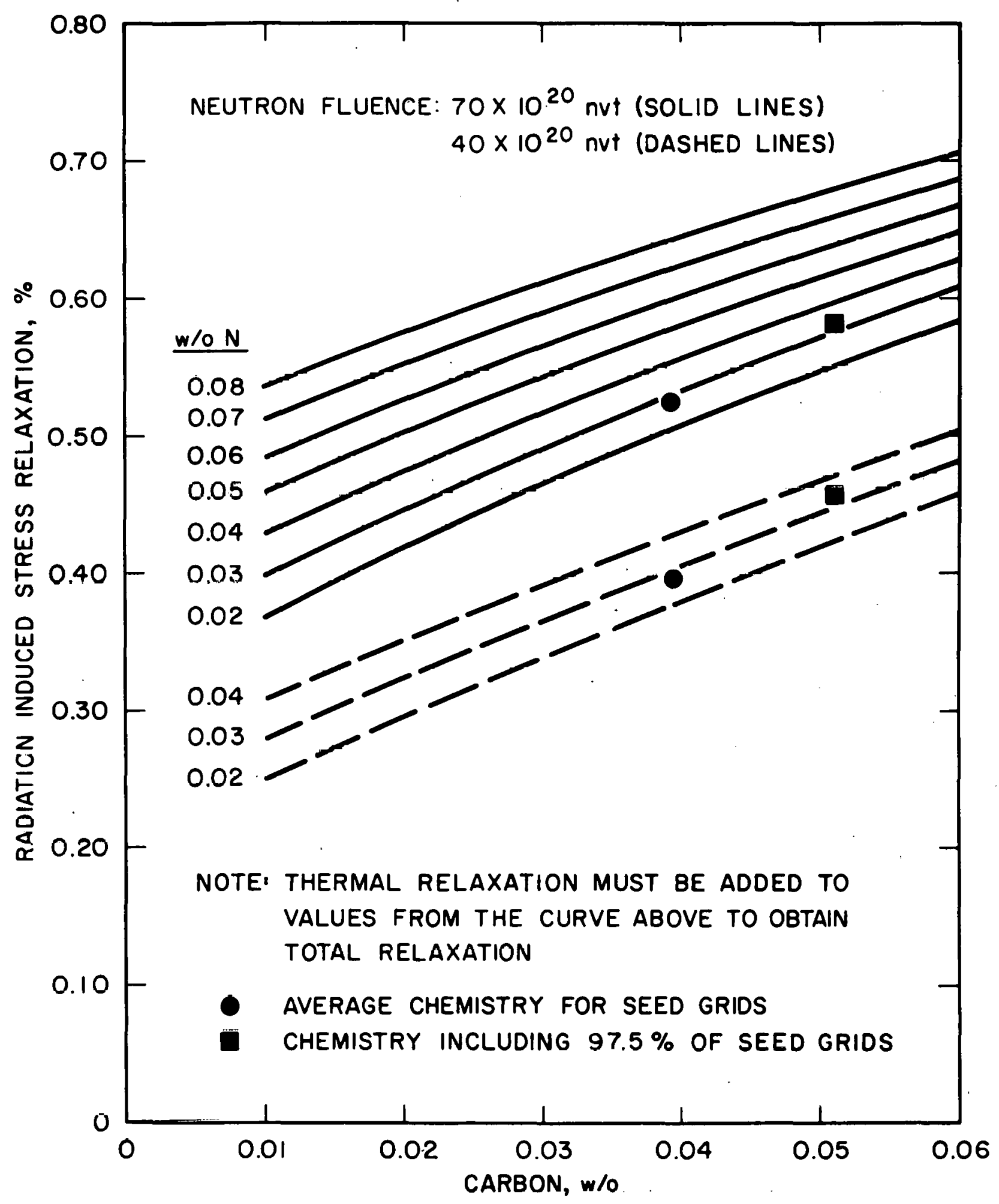

Figure D-10. Dependence of Radiation-Irduced Stress Relaxation on Carbon and Nitrogen Content of AM-350 
A series of structural tests evaluated the ability of the LWBR grid system to support the design loads without failure or degradation of functional capability. Fatigue, ultimate load, and simulated core flow tests were performed on actual grids as well as on selected grid components. A summary description of these tests and their pertinent findings are presented in Table.E.l.

The results of these tests clearly demonstrate the adequacy of the LWBR fuel rod support system (grids) to satisfy the functional requirements under both steady-state and cyclic loading conditions and under core flow conditions. The adequacy of the design of the blanket grid attachment members (connectors and tabs) was similarly verified. As described in Section II.E, it was necessary to locate these attachment members below the grid level. These structural tests also confirmed that the spot welds and brazed joints performed well for loads, deflections, and number of fatigue cycles beyond the LWBR design requirements. 
Test
Desigration

REM-215

Səed

Tэpe $\mathrm{V}$

REflector

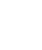

Fatigue tes to failure at grid loads 'tensile) which produced grid deflections wice the design ralues* (since grid was lcaded unidirectionally).

REM-216

Thpe III Blanket

Fatigue test to failure at grid loads (tensiie) which produced grid deflections twice the design ralues* isince grid was laaded unidirectionally).

REM-219

Seed

Fatigue test to determine effect of tensile load cycling on functional capability of seeć grids.
Data Table

Initial failure occurred at 29 times the design requirement; complete failure occurred at 64 times the design requirement.

No failure occurred in 91 times the mumber of Eesign cycles. The grid loads were doubled for an additional 42 times the rumber of design cycles without failure. Thus the margir. on cycles was at least 133 times the design requirement.

Initial failure occurred at 58 times the desi $\Xi n$ requirement; complete failure occurred at 179 times the cesign requirement.

a. No major structural failure in 36 times design cyclic requirement at a peak load of 1.8 times the maximum design load.

b. No major effect on the spring load-deflection characteristics.

REM = Reactor Engineering Mechanical

*Twice the design values at time of test. Later analysis reduced the expected design values. 


$\begin{array}{lll}\begin{array}{c}\text { Test } \\ \text { Designation }\end{array} & \begin{array}{c}\text { Grid } \\ \text { Type }\end{array} & \text { Test Objective } \\ \begin{array}{l}\text { REM-219 } \\ \text { Cont! }\end{array} & \\ & & \\ \text { REM-2خ̃ } & \text { Type III } & \begin{array}{l}\text { Fatigue test to determine } \\ \text { effect of tensile load } \\ \text { cycling on functional } \\ \text { capability of blanket grids. }\end{array}\end{array}$

c. No significant increase

in grid deflections with the number of cycles.

d. Number of cracks or other defects in the brazed

joints was not dependent on number of load cycles.

a. No structural failure in 36 times design cyclic requirements at a peak load of 1.8 to 2.0 times the maximum design load.

b. No deperdence of spring loaddeflection characteristics on load cyciing.

c. Grid deflecticns did not vary significantly with load cycling.

a. External connectors - stems between grid and lug were reduced in cross section (by about 28 percent. No effect on fatigue life and no connector damage after 10 times the number of design cycles at 2 times the-design loads (tensile), or after an additional 10 times number of design cycles at 2.5 times the design loads. 
Test
esignation

\section{REM-220A}

(Cont)

\section{Compression Type III Fatigue Blanket}

Test

\section{Single Connector Fatigue}

Gr:d Type

Blanket Test Objective

Təst Findings

Data Table

b. Interaal tab connectors (with 1 of the 12 guide tube screws remove - from a tab). Tab aljacent to tab witr. the missing screw failed after 15 times the rumber o= ciesign cycles at 3.1 times the design load (tensile..

No connector or tab damage after 10 times the number of design

Fatigue test $=0$ determine buckling resistance of internal tab comections and external ost connectors $c:$ blanket grids.

Fatigue test of single conrectors under cyalic tensile and compressive loads to c.termine buckling alequacy of blanket external =onnəctor design (with offset lugs ). cycles at peak compressive soads of 1.35 times the design

requirement.

Conservetisms in zests:

a. Sten connecting lug with grid was reduced zjout 28 percent in cross section.

b. Lug offset from vertical by 0.026 inch (more susceptible to backling).

One connectcr craaked after 9 times the numjer of design cycles at 2. 7 times the maximum design load. Another sonnector did not fail or crack af 20 times the number of design zycles at 2.3 times the maximum desïgn load, even with an D.053-iszh offset. of the lug stem from vertical. 
TABLE E-I (Cont)

\begin{tabular}{lll}
$\begin{array}{l}\text { Test } \\
\text { Designation }\end{array}$ & $\begin{array}{c}\text { Grid } \\
\text { Type }\end{array}$ & \multicolumn{1}{c}{ Test Objective } \\
\hline Tab & Blanket & $\begin{array}{l}\text { Ultimate compressive load } \\
\text { test to failure to determine } \\
\text { Ultimate }\end{array}$ \\
Load & & $\begin{array}{l}\text { adequacy of blanket tab } \\
\text { design. }\end{array}$
\end{tabular}

$\begin{array}{ll}\text { Grid } & \text { Type III } \\ \text { Ultimate } & \text { Blanket } \\ \text { Load } & \end{array}$

Ultimate load test to failure to determine adequecy of grids during maximurm loading conditions.

REM-3
9 seed Grids, 8 Type III Blanket

Grids, 6

Type $\mathrm{V}$

Reflector

Grids
Flow test to determine grid performance under similated core flow conditions.
Data Test Findings

E. 4

a. Tabs with design offsets failed by buckling at a load of 2.8 times the design load.

b. Tabs with offsets about double the design value failed by buckiing at loads of 2.2 to 2.5 times the design load.

a. One grid experienced end plate buckling at a load of 3.6 times the maximum design load, and tab tensile failure at a load of 10.9 times the maximum design load.

b. A second grid experienced end plate buckling at a load of about 3.1 times the maximum design load:

c. A third grid experienced tab buckling at a load of approximately 3.1 times the maximum design load.

Testing included a total of 1500 hours cold (less than 500F) flow testing and 2400 hours hot (greater than 500F) flow testing. No grid structural or dimensional problems were observed. Grids remained structurally sound with no cracks at dimples or springs. Mechanically adjusted cells similar to core grid cells showed no unusual
E. 4 
Test

Designaticn

Gric̄

Type

REM-3

(Cont)
Lat $\equiv$ raI load on grid

bout:daries to simulate LOC; where a blanket grid may be compressed between expancirg guide tube and ref-zctcr shell.
Data

Test Findings

Table

ronaitions following testing

'such as cracks, deformation, or heavy crua buildup). Grids pro-

vided adequate support to the

iuel rods to prevent excessive

vear as eridenced by examination of many thousand rod-to-grid contact points. No loss in spring force or rod-to-rod spacing was reported.

Grid cont Eined simulated rods in cells between inner and outer boundaries. Grid remained intact after a maximum deflection of 3.290 inch at a static load of 2270 pounds, maintaining a coolable Ђeometry. Maximum interference expected to occur inpile is about 0.0 iO inch less than that determined to cause plastic deformation. 
TABLE 'E-2. GRID FATIGUE TEST SUMMARY

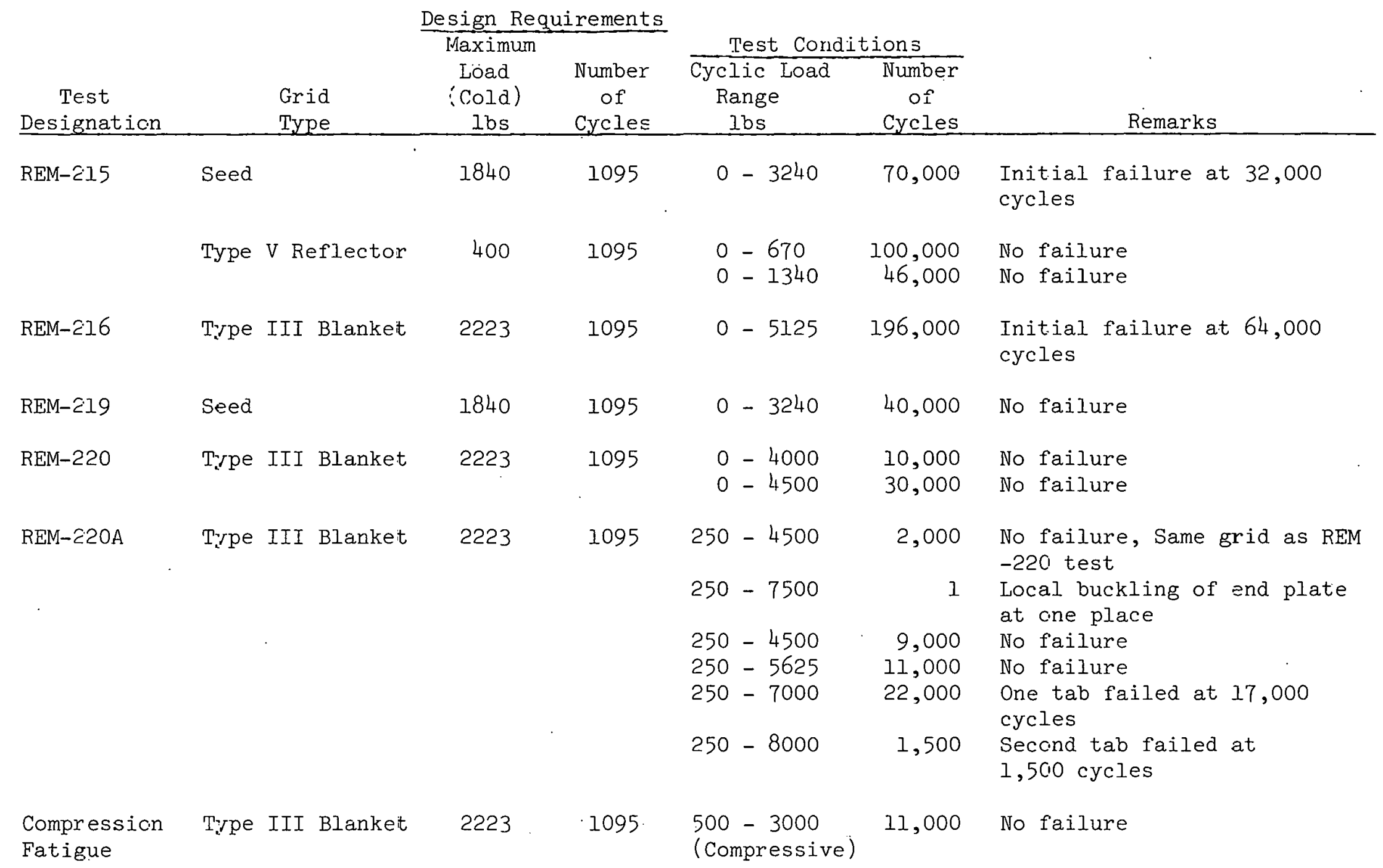


TABLE E-3. BLANKET GRID CONNECTOR FATIGUE TEST SUMMAPY

\begin{tabular}{|c|c|c|c|c|c|c|c|}
\hline $\begin{array}{c}\text { Test } \\
\text { Connector }\end{array}$ & $\begin{array}{c}\text { Reductior } \\
\text { in Stem } \\
\text { Cross-Secticnal } \\
\text { Area, } \\
\% \\
\end{array}$ & $\begin{array}{l}\text { Offset } \\
\text { of Lug } \\
\text { from } \\
\text { Vertic } 1, \\
\text { Incl. }\end{array}$ & $\begin{array}{l}\frac{\text { Iesign Requi }}{\text { Maximum }} \\
\text { Ioad (Cold) } \\
\text { (lbs) }\end{array}$ & $\begin{array}{l}\text { ments } \\
\text { of } \\
\text { Cycles }\end{array}$ & $\begin{array}{c}\text { Test Condi } \\
\text { Cyclic Ioad } \\
\text { Range } \\
\text { (Ibs) }\end{array}$ & $\begin{array}{c}\text { ions } \\
\text { Number } \\
\text { of } \\
\text { Cycles }\end{array}$ & Remarks \\
\hline 1 & 28 & $0.02 \epsilon$ & 208 & 1095 & \pm 560 & 10,000 & $\begin{array}{l}\text { Crack occurred } \\
\text { at } 10,000 \text { cycles }\end{array}$ \\
\hline 2 & 28 & 0.026 & 208 & 1095 & \pm 490 & 11,000 & $\begin{array}{l}\text { No failure (or } \\
\text { cracks) }\end{array}$ \\
\hline \multirow[t]{2}{*}{3} & 28 & 0.053 & 208 & 1095 & \pm 490 & 11,000 & No failure \\
\hline & & & & & $\pm 49 \mathrm{C}$ & 11,000 & No failure \\
\hline
\end{tabular}


TABLE E-4. ULTIMATE LOAD TEST SUMMARY

\begin{tabular}{|c|c|c|c|c|}
\hline $\begin{array}{c}\text { Test } \\
\text { Component }\end{array}$ & $\begin{array}{c}\text { Maximum (cold) } \\
\text { Design Load } \\
\text { Ijs }\end{array}$ & $\begin{array}{l}\text { Failure } \\
\text { Load } \\
\text { Ibs } \\
\end{array}$ & Failure Mode & Remarks \\
\hline Type III Blankət & 2223 & 8,000 & Endplate buckling & \\
\hline & & 24,200 & Tab tensile failure & \\
\hline Type III Blankət & 2223 & 7,000 & Endplate buckling & \\
\hline Type III Blankət & 2223 & 7,000 & Tab Buckling & \\
\hline Blariket Tabs & 132 & 460 & Tab Buckling & Two tabs with 0.090 irich offset \\
\hline Blariket Tab & 91 & 230 & Tab Buckling & One tab with 0.090 inch offset \\
\hline Blarket Tab & 91 & 200 & Tab Buckling & One tab with 0.090 inch offset \\
\hline Blarket Tab & 91 & 260 & Tab Buckling & One tab with 0.030 inch offset \\
\hline Blanket $\mathrm{Tab}$ & 91 & 260 & Tab Buckling & One tab with 0.057 irch offset \\
\hline
\end{tabular}


APPENDIX F - SPRING FOLLOW

The ability of the grid cell spring to exert a positive force on the fuel rod at all times during core life is an important consideration in assuring that the fuel rod remains seated on the fixed dimples. This appendix describes the method used to evaluate this "spring follow" ability. Since many factors, which are time and location dependent, affect the available spring force, a special computer program was employed to perform the actual, tedious. computations. These calculations may be thought of as occurring in three phases.

A. Phase I - Calculation of Initial Deflection and Spring Force

After the grids have been assembled in the fuel module assemblies and have initially been heated to temperature and pressurized, the grid cells and fuel rods have undergone several changes which affect the spring follow. The initial deflection at this lime is given by:

$$
d_{\text {hot }}=K_{1}-F S P+1 . S_{1}\left(D-K_{2}\right)-2(\text { dimple })-\text { wear }- \text { OTP }- \text { SET }
$$

where

$$
\begin{aligned}
d_{\text {hot }}= & \text { Initial hot, pressurized, spring deflection (mils) } \\
\text { FSP = } & \text { Initial position of the spring in its free or undeflected } \\
& \text { position relative to the cell centerline, cold (mils) } \\
\mathrm{D}= & \text { Initial fuel rod outside dianter, cold (mils) } \\
\mathrm{K}_{1}= & \text { Radius of probe used to measure FSP (mils) } \\
\mathrm{K}_{2}= & \text { Diameter of probe used to measure FSP (mils) } \\
\text { dimple = } & \text { Deflection of one dimple (mils); both dimples are assumed to. } \\
& \text { deflect equally } \\
\text { wear = } & \text { Decrease in fuel rod diameter due to installation scratches (mils) } \\
\text { OTP = } & \text { The change in deflection upon going to operating temperature and } \\
& \text { pressure (mils) }
\end{aligned}
$$

The first two terms provide the initial cold deflection of the spring by the inspection probe. This deflection is then corrected by the third term to account for installation of the actual fuel rod, whose diameter is larger than the inspection probe. The 7.5 proportinnality factor converts the diameter change to a spring deflection change for the LWBR grid cells with the 120 degree spring-dimple configuration. 
Spring rates of the fixed dimples were obtained from empirical data for test grids. When multiplied by the actual (cold) spring force in the cell, the reciprocal of the dimple spring rate gives a measure of the deflection loss due to dimple movement when the rod is inserted.

Scratching of the fuel rod cladding during rod installation could result in a 1 mil maximum depth scratch. This maximum depth for one contact point was multiplied by a proportionality coefficient ( 1.68 average) to convert to a spring deflection loss.

The OTP allowance accounts for

1. The differential grid-fuel rod thermal expansion

2. The fuel rod diameter decrease due to elastic contraction when the core is pressurized.

When a spring is deflected such that some portion ef the epring experiences stresses greater than the elastic llmil, some amount of plastir deformation will occur. Thus, when the load is removed, the spring will no longer return to its nriginal "zcro" point. This permanent "zero-shift" is defined as the spring set. The deflection loss due to this set is equal to the difference betweell the actual fuel rod diameter (including the weld bead helght at the cnd plug we 1.d) and the diameter of the largest inspection probe used prior to fuel rod installation, times a proportionality coefficient. The proportionality coefficient is different for the vârlous sprilig deniens (ceed, hlanket, normal or wide reflector).

The initial not sprlny furce is then calnulated frum this initial hot spring deflection and a "reference" force-deflection curve l'ui AM-350 blid sprincr of the LWBR design. Since the reference force-deflection curve was measured at room temperature, the hul spring force is shtained by multiplying the cold spring force by an 0.88 multiplier to accumt for the redurtinn in the modulus of elasticity with the increase in temperature.

\section{B. Phase II - Calculation of the Force and Deflcction at the Time of Initial Criticrality}

The initial hot spring force is used to calculate the amount of thermallyinduced stress relaxation. This includes all the time-dependent plastic strain which occurs at constant deflection from the time the grid is first brought to 
temperature until initial criticality. The amount of relaxation depends on the initial spring force and the time at temperature. This is calculated using a relationship derived from thermal relaxation experiments on simulated grid springs.

$$
1-\frac{F}{F_{0}}=\frac{F_{0}}{F_{n}} 10^{-1.18} t^{0.155}
$$

where

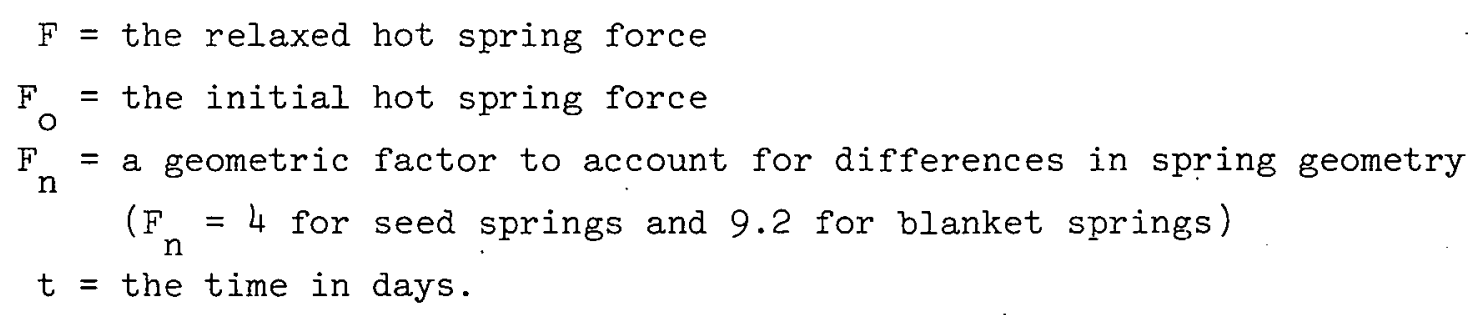

The initial hot spring force is reduced by the calculated amount. A new force-deflection curve is then generated, since the spring force at the initial hot deflection has been reduced by this amount. A small adjustment is made to the initial hot deflection to account for

1. Corrosion of the AM-350 grid contact points during the hot time prior to initial criticality.

2. The dimple deflection recovery due to the reduction of the spring force. These adjusted values become those used at O EFPH (Effective Full Power Hours) at the time of initial criticality.

\section{Phase III - Calculation of the Spring Force During Core Life}

The available spring force at any time after initial criticality depends on the shape of the force-deflection curve at that time, which is dependent on:

a. The force-deflection curve at 0 EFPH

b. The deflection at $0 \mathrm{EFPH}$

c. The amount of irradiation-induced stress relaxation.

The irradiation-indliced force relaxation is the neutron fluence-dependent conversion of elastic to plastic strain which occurs during core operation. The magnitude of this component of the force relaxation is given by the following equation:

$$
\left(1-\frac{F}{F_{i}}\right)=0.048+1.07\left[1-C_{1} e^{- \text {III } 1 \phi t}-\left(1-C_{1}\right) e^{-i n t} 2^{\phi t}\right]
$$


where

$$
\begin{aligned}
F= & \text { spring force after radiation-induced reduction } \\
F_{i}= & \text { spring force at initial criticality (at } 0 \mathrm{EFPH}) \\
C_{1}= & 1.01114-3.23124 \mathrm{C}-2.10849 \mathrm{~N} \\
m_{1}= & 0.00423+0.065218 \mathrm{C}+0.039212 \mathrm{~N} \\
m_{2}= & 0.208876 \\
\phi t= & \text { fast neutron fluence (E greater than } 1 \mathrm{Mev}) \text {, in units of } \\
& 10^{20} \text { neutrons/square centimeter }
\end{aligned}
$$

with $\mathrm{C}$ (carbon content) and $\mathrm{N}$ (nitrogen content) in units of weight percent.

This equation provides the fractional relaxation of the spring foree since initial criticality. When multiplied by the thermally...induced fractional relaxation (before initial criticality), the total fractional relaxation of the spring force $\left(f_{r}\right)$ is obtained.

Since this reduction in spring torce occurs at constant detlection, a new spring force-deflection curve is calculated, as illustrated in Figure F-1. The shape of the new curve is given by

$$
\begin{aligned}
F(d)= & F_{i}(d)\left[1-3\left(1-f_{r}\right)\left(1-\frac{d}{d_{i}}\right)^{2}\left(\frac{d}{d_{i}}\right)\right] \text { "Curve Flattening Term" } \\
& -F_{i}\left(d_{i}\right)\left(1-f_{r}\right)\left[1+\alpha\left(1-\frac{d}{d_{i}}\right)\right] \quad \begin{array}{l}
\text { "Curve Translation and } \\
\text { Tiutatiun Terms" }
\end{array}
\end{aligned}
$$

where

$$
\begin{aligned}
F(d)= & \text { spring force as a function of deflection (d) } \\
F_{i}(d)= & \text { force-deflection curve at } 0 \mathrm{EFPH} \text { as a function of deflection (d) } \\
F_{i}\left(d_{i}\right)= & \text { initial (0 EFPH) force-deflection } \\
f_{I^{-}}= & \text {total fractional relaxation of the spring force } \\
\alpha= & \text { curve rotation coefficient }=0.025 \text { (best estimate from } \\
& \text { empirical data). }
\end{aligned}
$$

The new force-deflection curve is schematically illustrated in Figure F-l. During the time period under consideration, however, changes have occurred in the amount of spring deflection due to fuel rod wear, diametral shrinkage, shrinkage into pellet tapers or chip voids, corrosion of the rrid contact points, and recovery of the dimple deflection because of the reduced spring 
force. The deflection loss due to these factors is subtracted from the spring deflection at the start of the EFPH interval under consideration to arrive at a new spring deflection (Figure F-I). This new spring deflection value is used with the new force-deflection curve calculated above to arrive at the spring force available at the time under consideration.

The factors contributing to the deflection loss are discussed below.

1. Cladding Wear

Contact of the cladding with the grid contact points (dimples and springs) causes wear grooves in the Zircaloy cladding, resulting in a decrease in spring deflection. Test data indicated that the maximum wear depth does not occur simultaneously at all three contact points. On the basis of test data, a conversion factor of 1.68 (best estimate value, rather than 3) for determining the deflection loss from the maximum single point wear depth was employed.

The wear model is dependent on the spring force. The spring follow calculations assumed that the spring force remained constant throughout the EFPH interval analyzed. In reality, the spring force (and hence the increment of cladding wear) decreased during this interval. The loss of spring deflection due to cladding wear was therefore conservatively overpredicted by this assumption.

\section{Corrosion}

The best-estimate corrosion rate of the AM-350 grid contact points may be expressed by the following relationship:

$$
\log y=-2.22568+0.299824(\log x)
$$

where

$$
\begin{aligned}
& y=\text { depth of oxide penetration (mils) } \\
& x=\text { corrosion time (hours) }
\end{aligned}
$$

The change in spring deflection $(\Delta d)$ is obtained from this single-surface corrosion depth (d) by:

$$
\Delta \mathrm{d}=\mathrm{Kd}
$$

where $\mathrm{k}=$ multiplier $=3$ for the best estimate case. Corrosion is not a major contributor to spring deflection loss. 


\section{Taper Follow}

Binary fuel pellets used in the blanket fuel rods were manufactured with tapered ends to minimize clad "ridging" at hot operating conditions. Clad "ridging" can generate high tensile stresses at pellet interfaces. The relatively thin non freestanding blanket rod cladding deforms onto the fuel pellets and eventually into the pellet tapers, resulting in a loss of spring deflection. The maximum loss in spring deflection at end-of-life in the standard blanket region was calculated to be 0.0023 inch, and 0.0039 inch in the power-flattening blanket region, using a calculated model based on test data.

\section{Diametral Shrinkage}

Shrinkage of the fuel rod cladding due to pressurization and irradiation will result in a loss in spring deflection equal to 1.5 times the diametral shrinkage. Diametral shrinkage values for each type grid were calculated as functions of neutron f'luence and grid level using the CYGRO fuel rod analysis computer program (Reference 1 ).

\section{Limple Def'lection Recovery}

As the spring force decreases because of stress relaxation, the deflection of the dimples decreases. This action tends to move the fuel rod toward the spring panel, resulting in increased spring deflection: One-half (50 percent of the initial hot dimple deflection is assumed to be the maximum recovery. The dimple and spring deflection is calculated by a simple force balance. The dimple deflection at the start of an EFPH cycle is given by

$$
\mathrm{DEF}_{\text {Dimple }}=0.5 \text { (initial hot dimple deflection) } \times \frac{F}{F_{0}}
$$

where

$$
\begin{aligned}
F & =\text { spring force at start of } \mathrm{EFPH} \text { cycle } \\
F_{0} & =\text { initial hot spring force, prior to thermal relaxation. }
\end{aligned}
$$

\section{REFERENCE}

1. J. B. Newman, J. F. Giovengo, L. P. Comden, "The CYGRO-4 Tuel Rod Analysis Computer Program," WAPD-TM-1300, July 1977. 
I. SPRING AT THE BEGINNING OF THE EFPH INTERVAL

2. RELAXATION CALCULATED. NEW SPRING CURVE CALCULATED

3. INCFEMENT OF WEAR FOLLOW

4. INCREMENT IN CORROSION FOLLOW

5. INCREMENT IN TAPER AND/OR PELLET CHIP VOID FOLLOW

1
$u$
0
0
0
0
0
$\frac{2}{\alpha x}$
0
0

6. INCREMENT DUE TO DIAMETRAL SHRINKAGE

7. DIMPLE RECOVERY

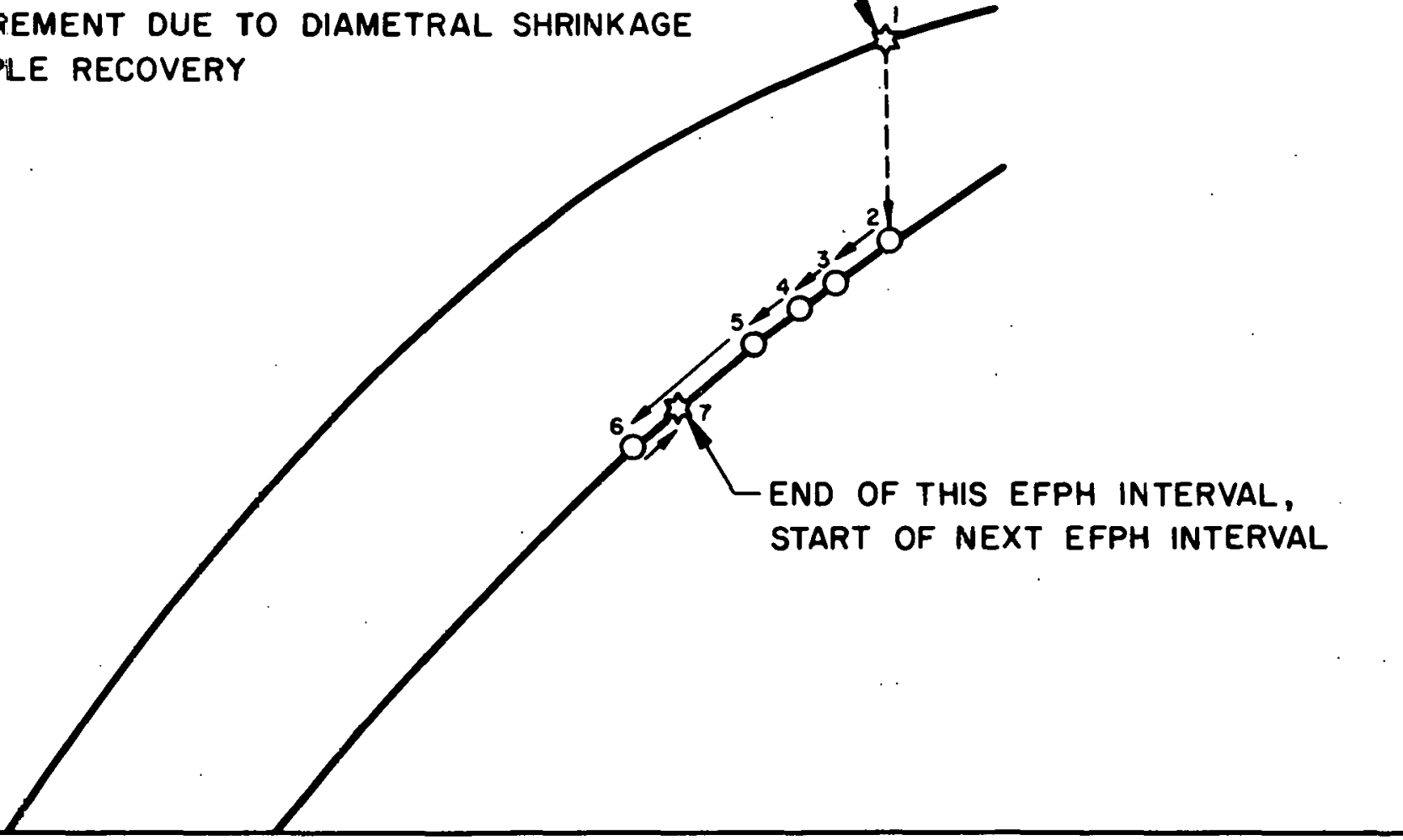

SPRING DEFLECTION

Figure F-l. Illustration of the Sequence of Calculations Performed During an EFPH Time Interval

END OF LAST EFPH INTERVAL, START OF THIS EFPH INTERVAL

END OF THIS EFPH INTERVAL,

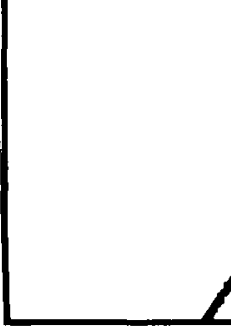

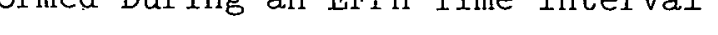

